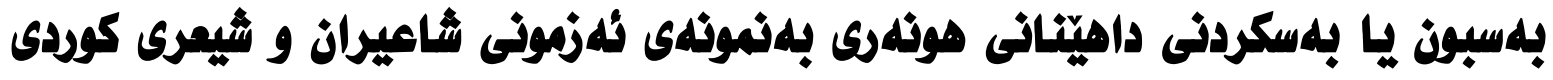

\section{ئلهرخلوان محمد عوبيّد}

بهشى زمانى كوردى، كوليّزّى بِهروهرده بو زانسته مروّايهتييهكان، زانكوى كهركوك، كهركوك، عيّراق. ئيمهيل: Amail.com

بهسبون يا بهسكردنى داهينانى هونهرى بهنمونهى ئهزمونى شاعيران و شيعرى كوردى ناونيشانى باسيكى

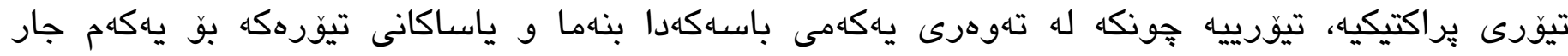

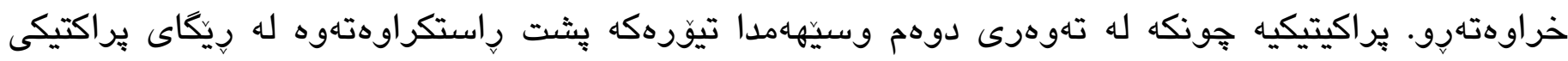
كردنى بوّجونهكان له سهار شيعر و ئهزمونى شاعيرانى كورد، جهامكى بهسبون يا بهاسكردنى داهينانى هونهاهيى

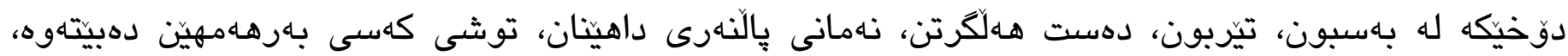

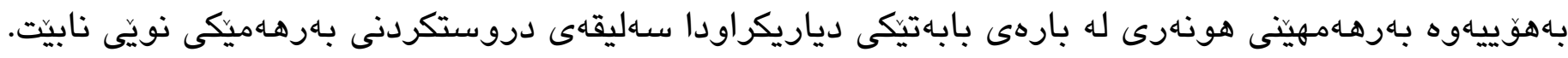

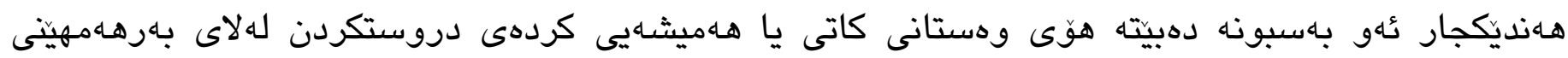

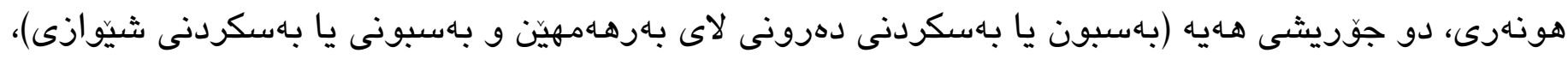

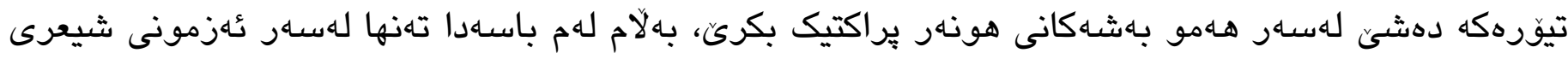

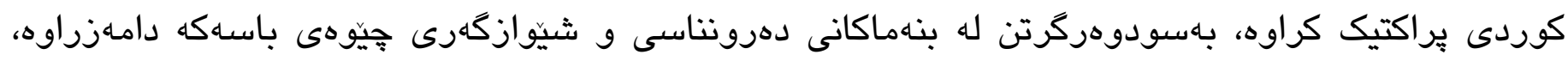

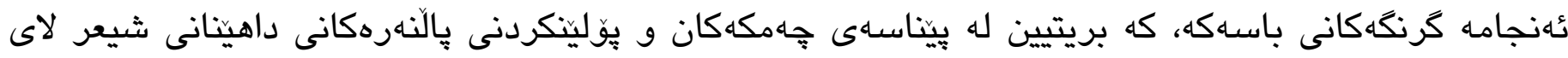

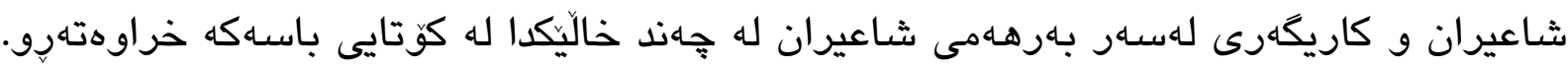

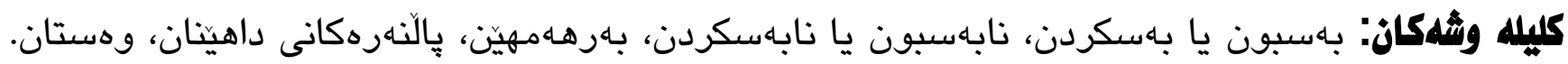




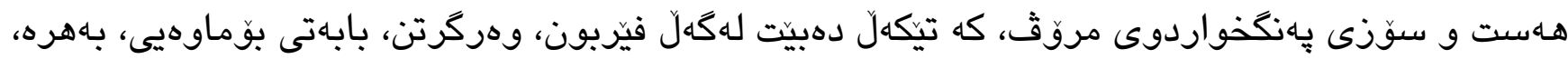

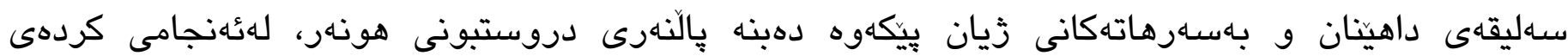

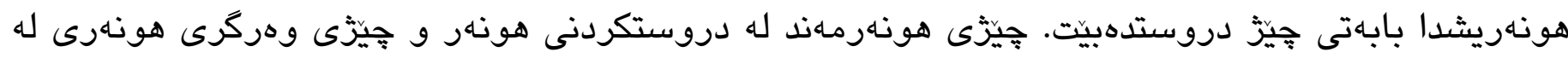

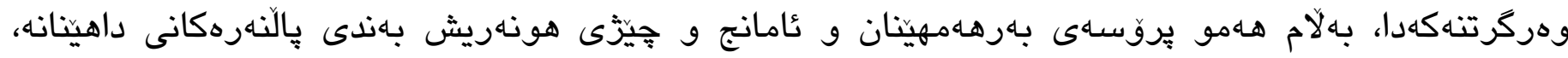

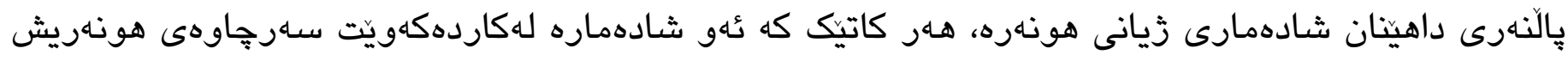

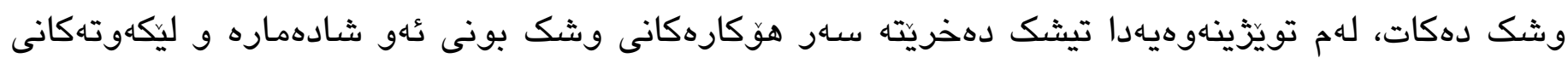

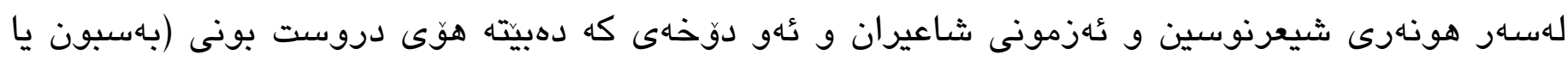
باسكرن له داهينان)دا.

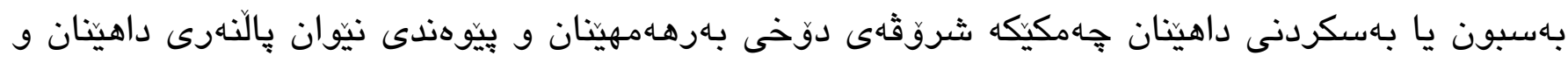

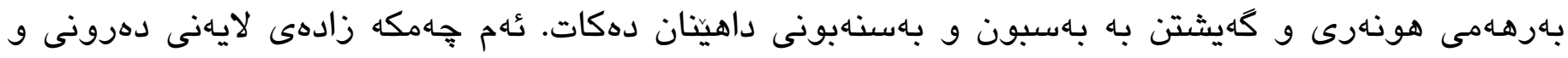

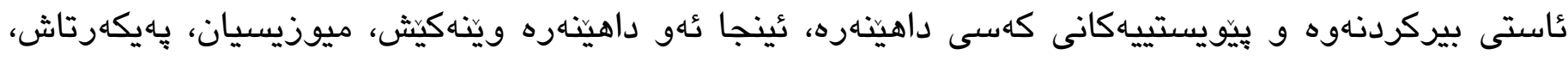

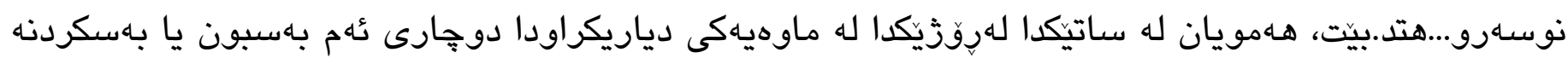

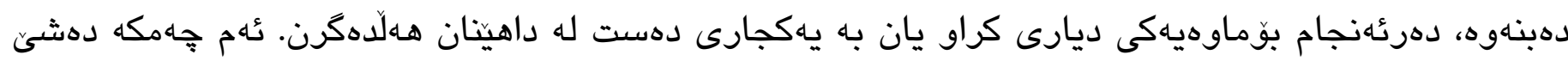

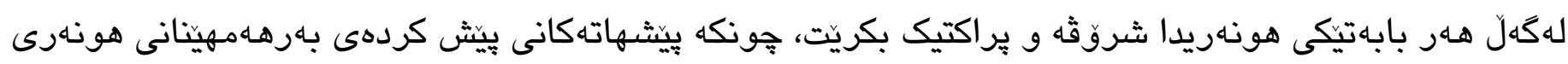

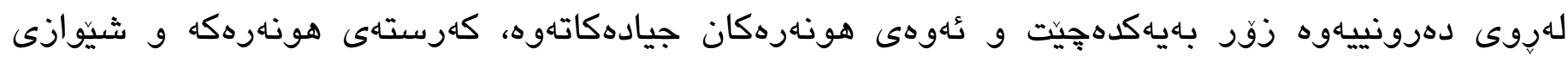

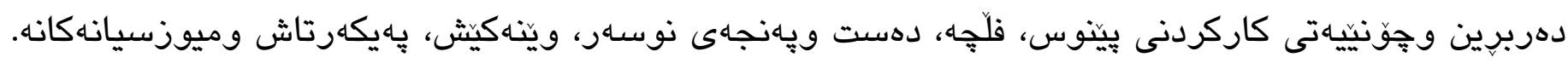

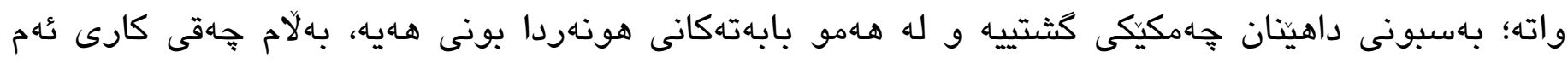

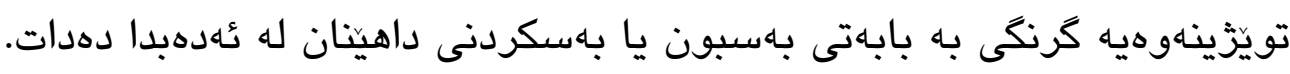
سنورى تويزّينهوه:

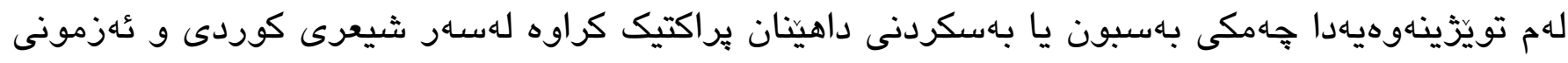

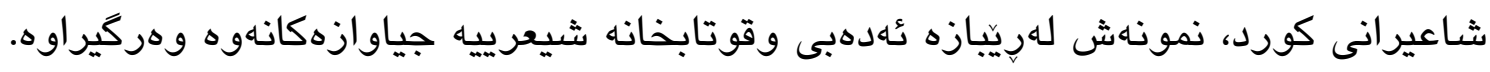

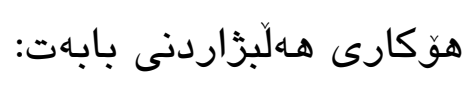

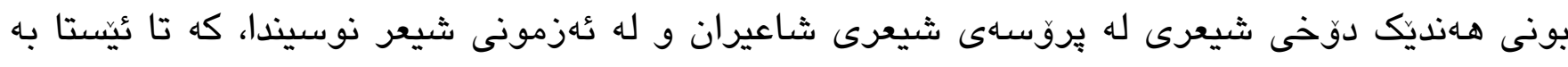

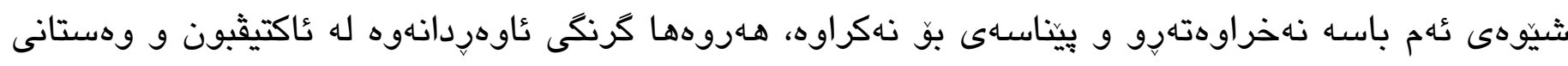

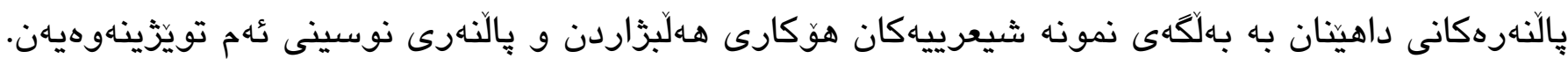

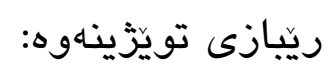

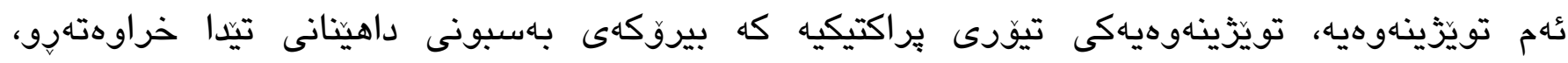

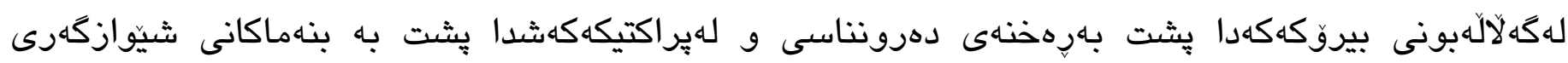
باهستراوه. 
بروكَرامى تويَّزينهوهكه:

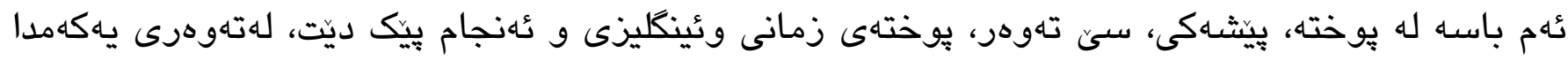

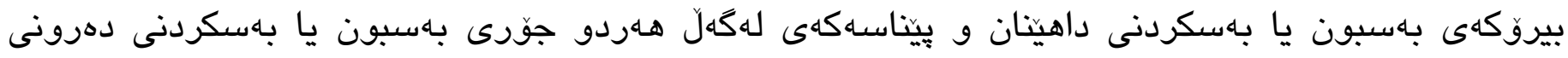

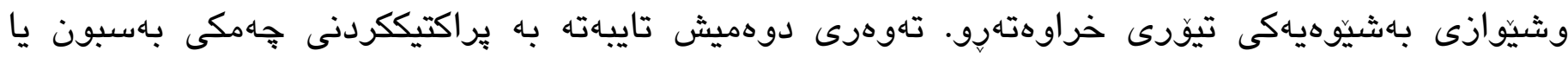

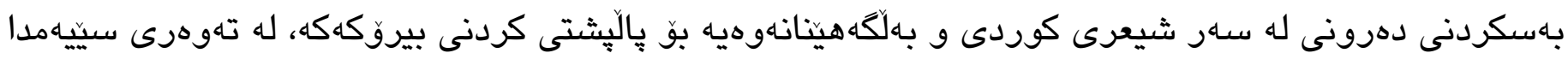

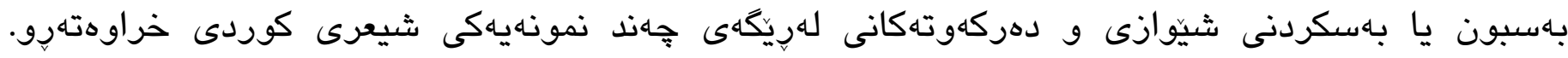

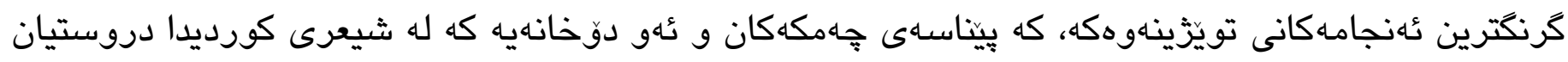

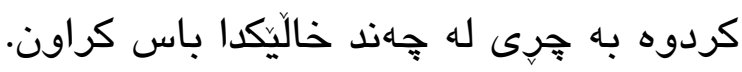

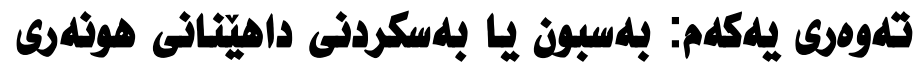

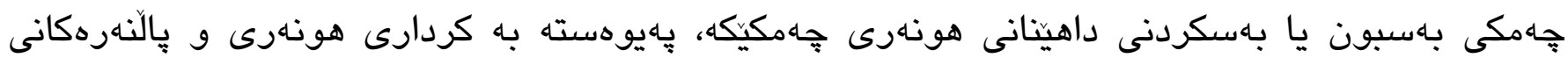

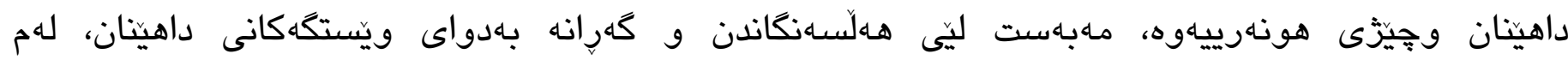

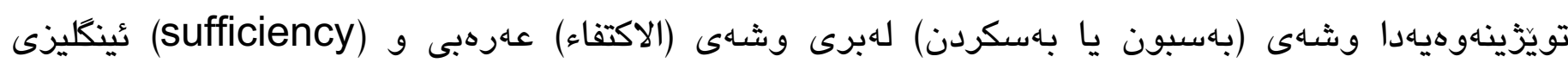

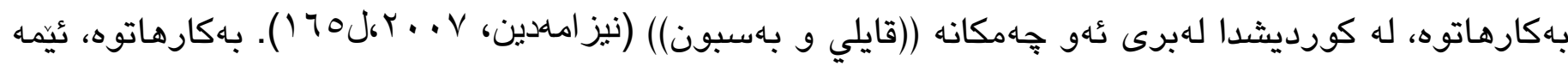

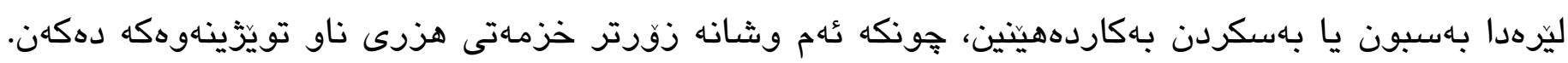

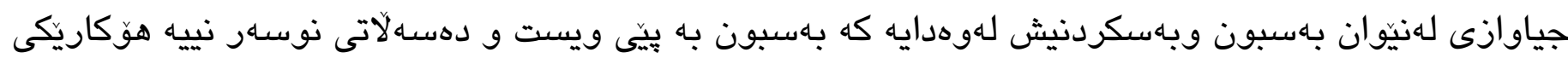

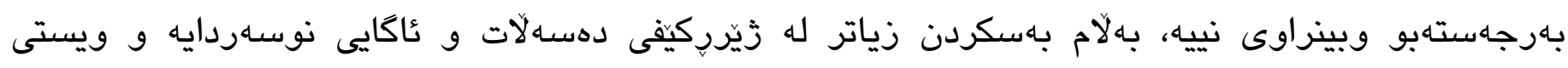

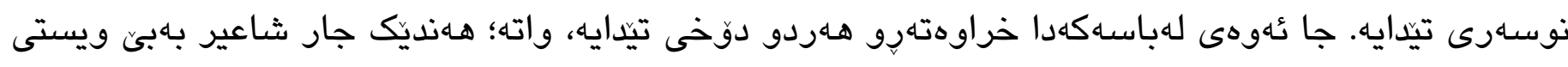

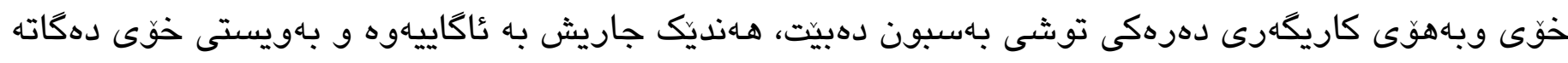

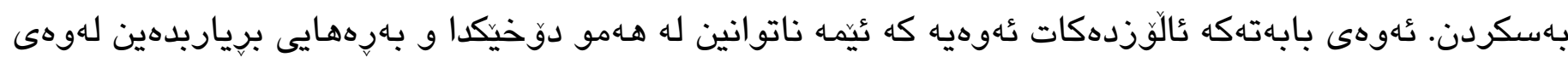

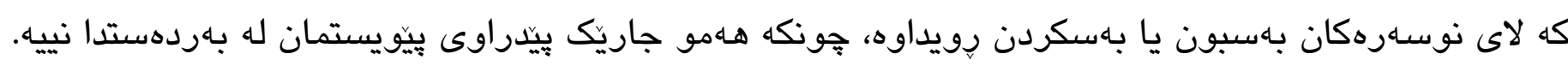

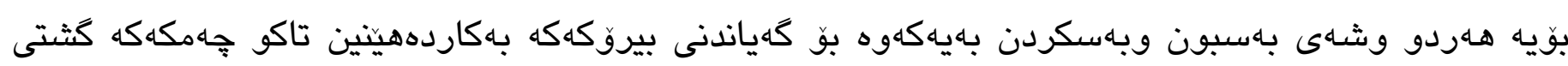

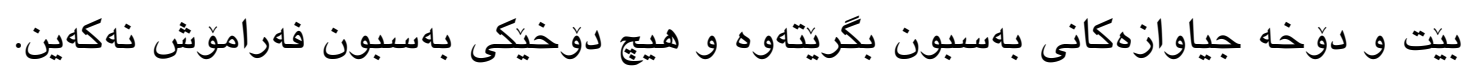

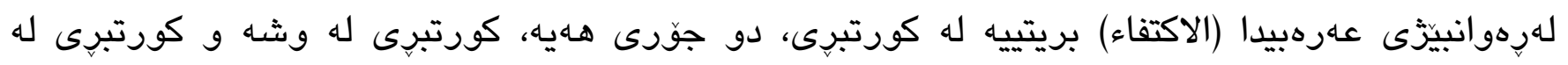

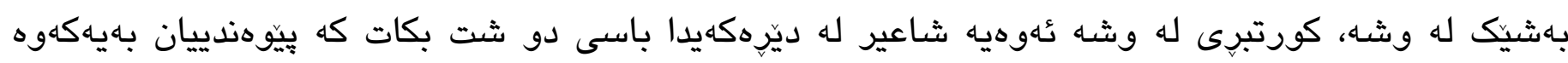

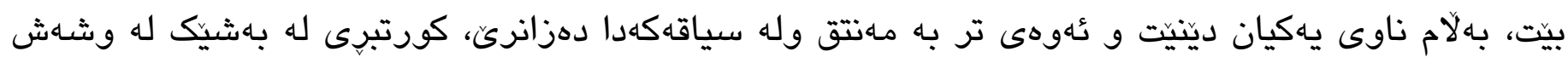

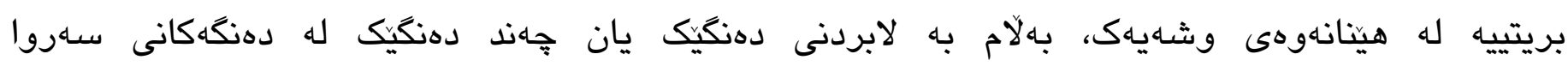

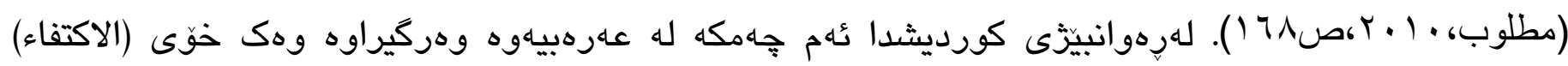

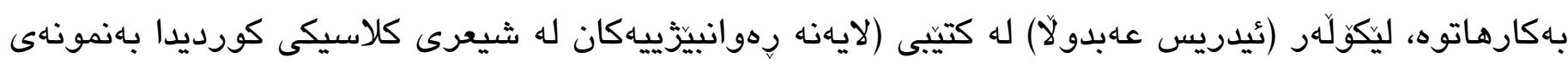




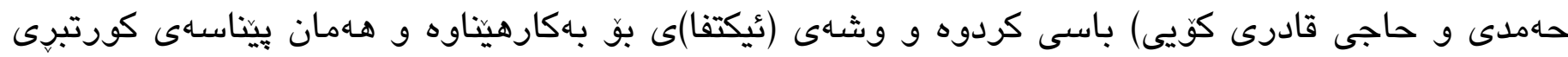

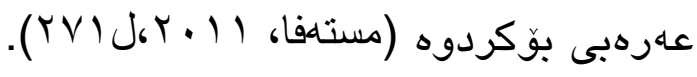

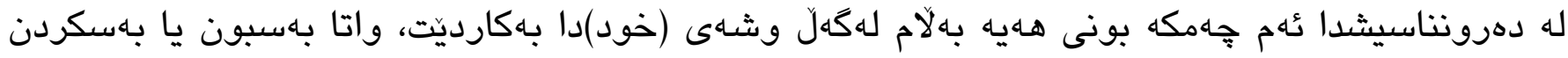
به خود (الاكتفاء الذاتى)، هـروهها له بوارى راميارى و عابورى و يهـروهردهش به شيّوهى بهسبون يا بهسكردنى خودى بهكارهاتوه، له هـموشياندا ماناى يشت بهستن به تواناكانى خود و دوركهوتناهوه له يارمـتييه دهرهكييهكان دهدات.

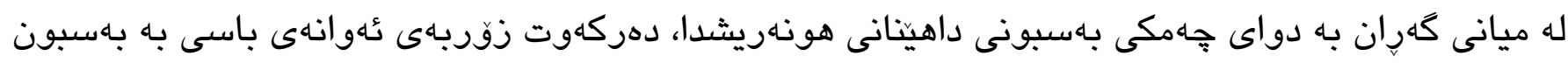

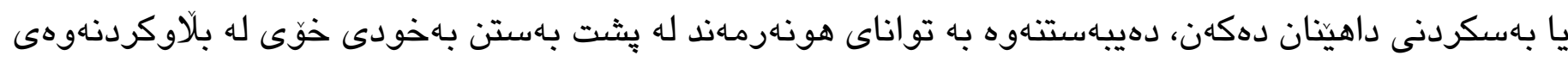

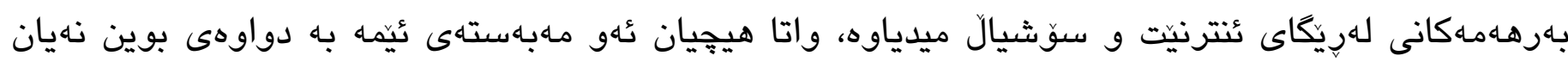

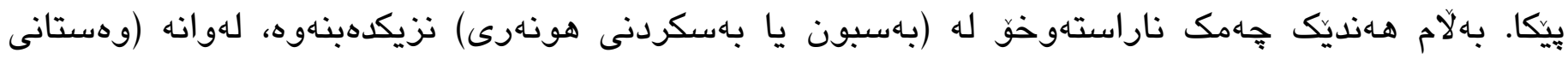

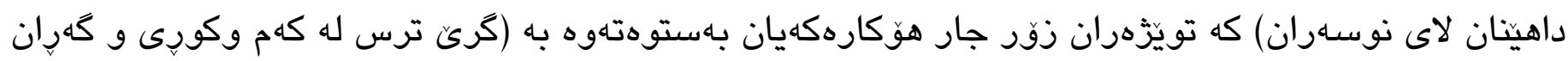

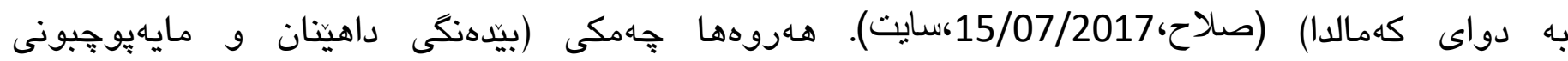

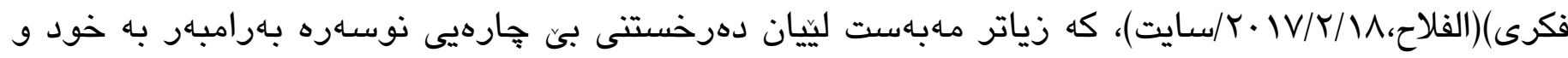

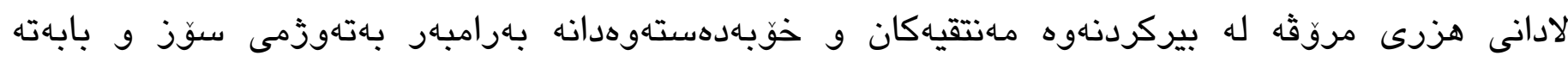

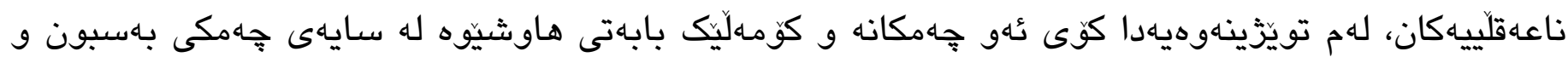
بهسكردندا كوكراونهتهوه، واته جههكى بهسبون يا بهسكردنى داهينان دهبيته جهاهريكى كَهوره و بابهتهكانى

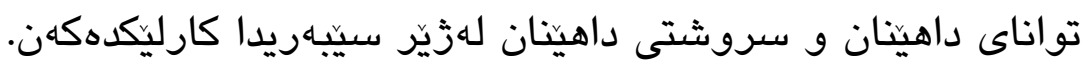

\section{بلهبون يا بلهكردنى داهينّان جيبيه؟}

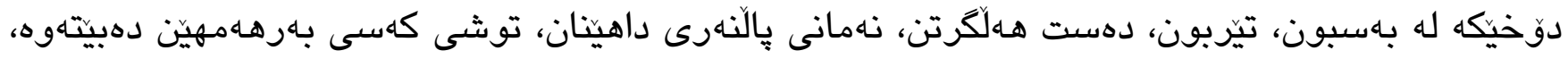

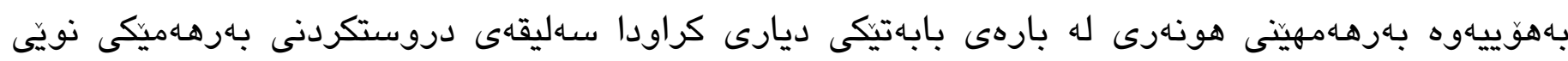

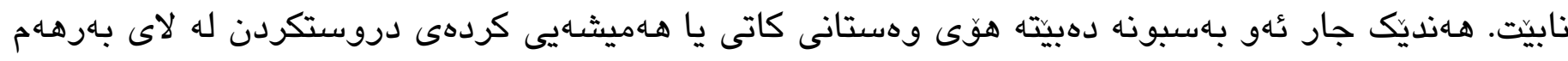

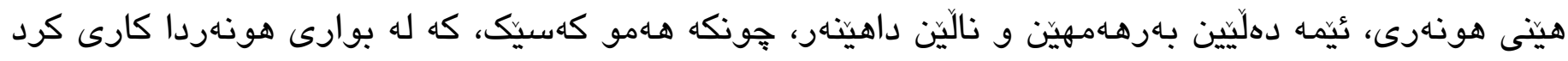

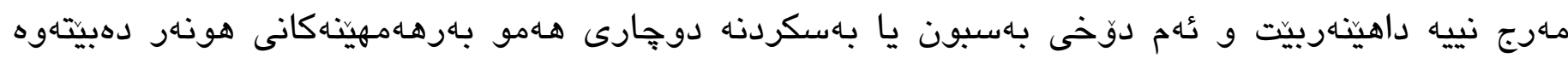
(داهيناهر و لاسايى كهرهوه).

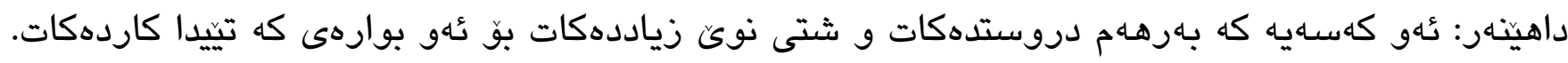

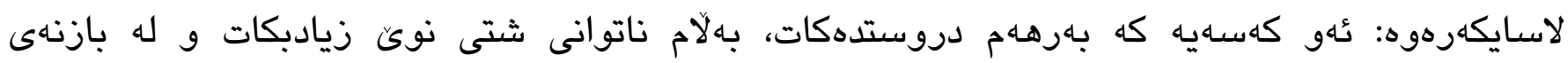
لاسـايكردناهوهى هونهريدا دهمينيتهاهه و نايهرِيتهوه بوّ بوارى داهينان. بوّنمونه ثُهوانهى كه شيعر دهنوسن زوّرن،

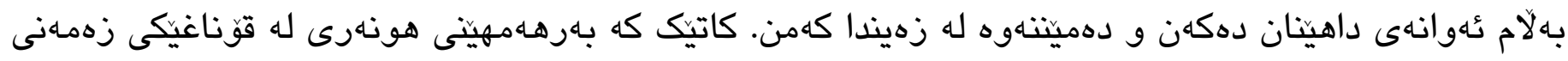

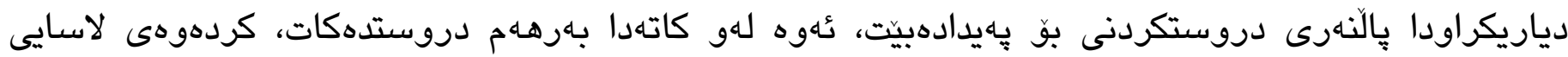




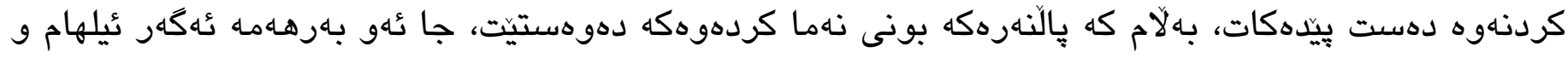

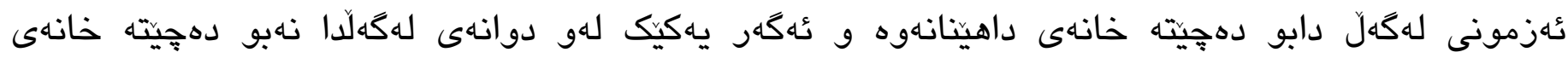

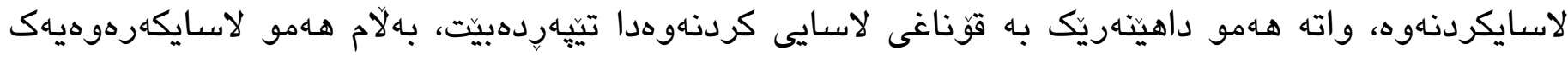

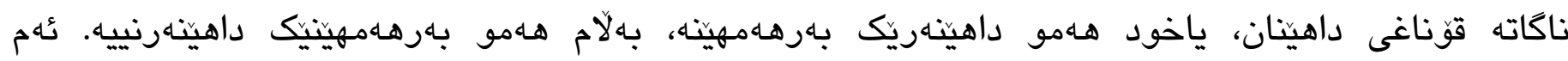

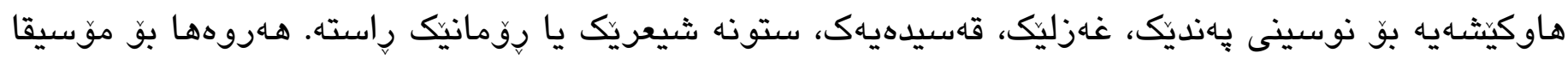
و ويناكينشانيش هـه وايه. تئوهى كه تهنها لاسايكردنهوهكه دهكات لاسـايكردنهوهكه بهسبون يا بهسكردنى لا دروست دهكات و تئوهش كه داهينان دروست دهكات، داهينانهكه بهسبون يا بهسكردنى بو دروست دهكات،

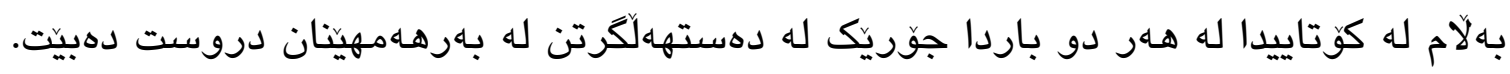

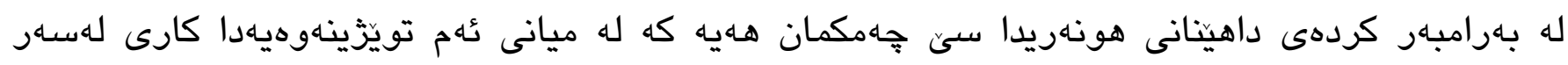
دهكهين ثٔهويش (بهسبون و بهسكردن و وهستانى داهينان)ه، هـهر يهكيك لهم جهامكانه هوكار و دهرهاويشتهى

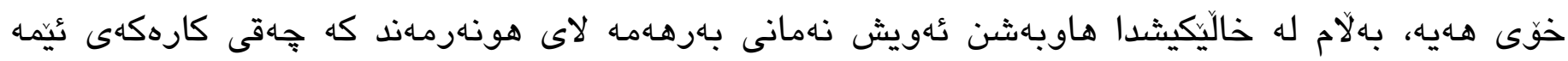
دهبيت. دو جوّر بـسبون يا بهسكردنى داهينانى له لاعى بهرهـمهيّن هـان:

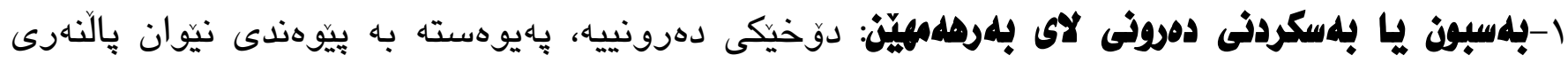

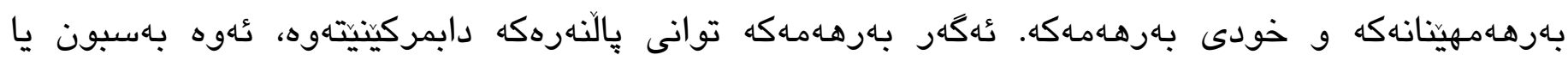

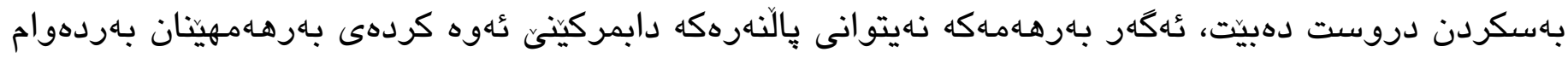
دهبيت. كه بهسبيونيش دروستبو ناخى مروق دهشي دو حالذتى بهاهـاردابيت:

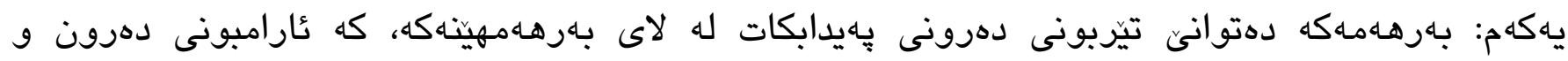

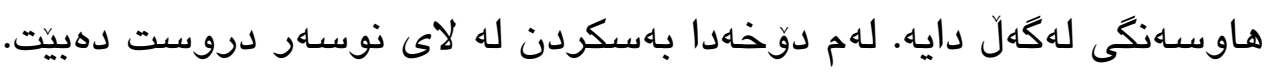

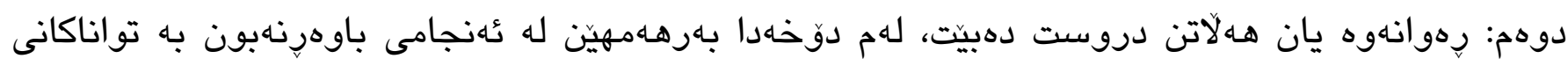
خوى، يان له ئهنجامى رهشبينييهوه، ياخود رِازى نهبون له داهينانهكهى، يا له تُهنجامى تيّرنهبونى روحييهوه باهبونى داهينانى للهلا دروست دهبيت. بـاسبونهكه له ئهنجامى ناسـاهامكيرى دهرونى باءرهـمهيتهاهوه دروست

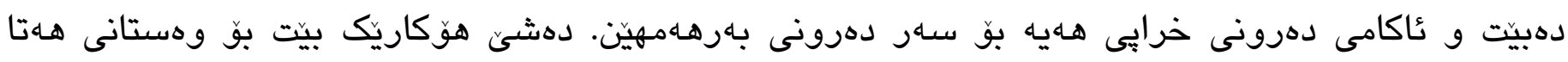
هـانى له داهيناندا.

- تيهو هوَكارانهى كه كاريكارى له سهار باهبون يا بهسكردنى دهرونى هـهيه:

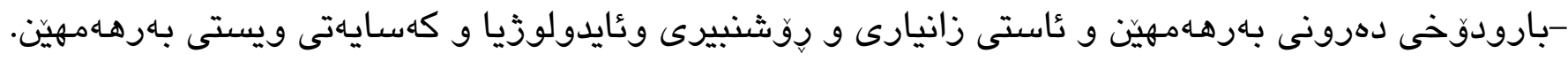

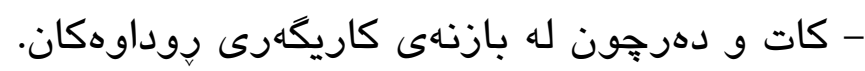

$$
\begin{aligned}
& \text { - فهرهـنَ و كولتورى كومـلخًا. } \\
& \text { - }
\end{aligned}
$$

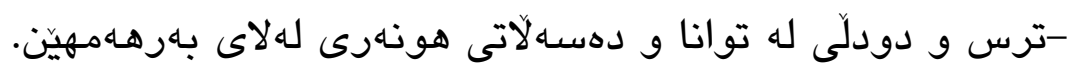


دهشيّ كهسانيك وابيربكهنهوه، كه ئهم بهسبونهى ئيمها باسى دهكهين ههمان بابهتى (قهردبوكردنهوهى

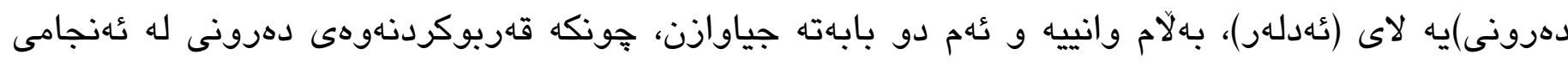

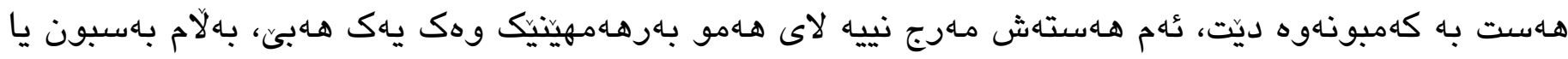

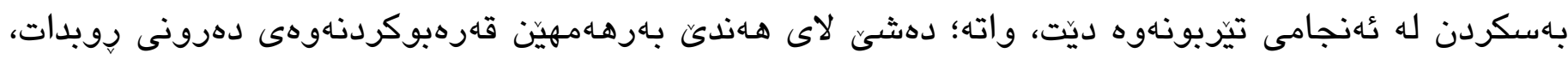

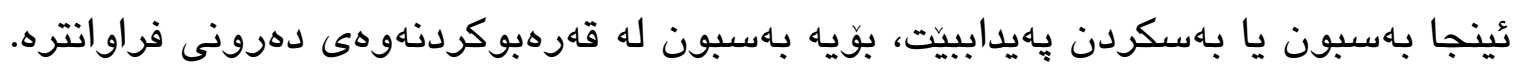

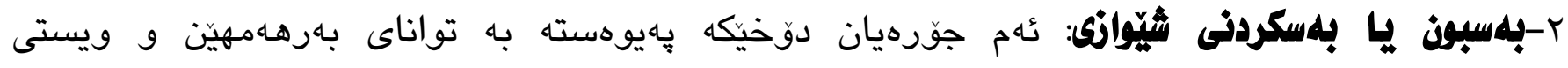

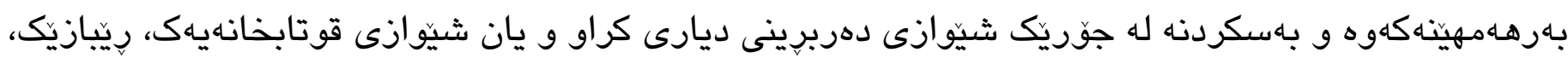

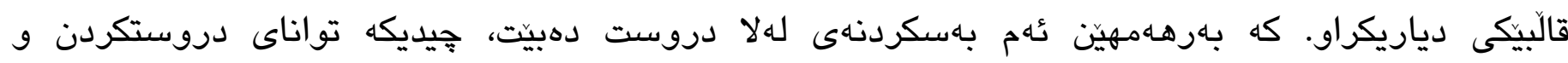

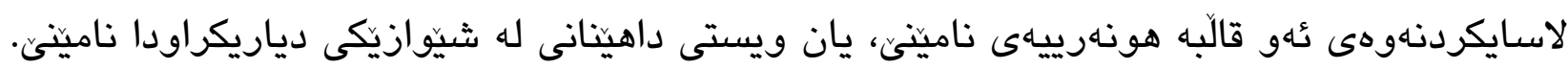

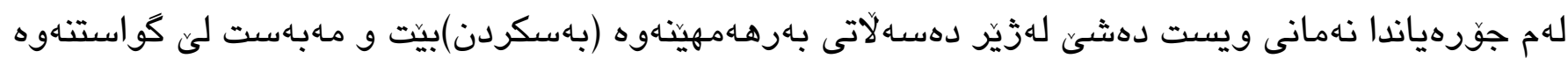

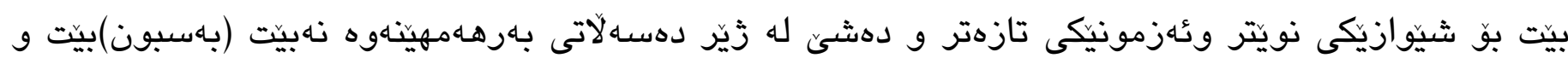

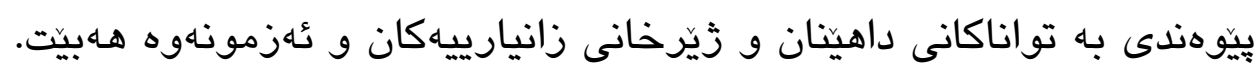

\section{هوّكارهكانى بهسبون يا بلهكردنى شيّوازى:}

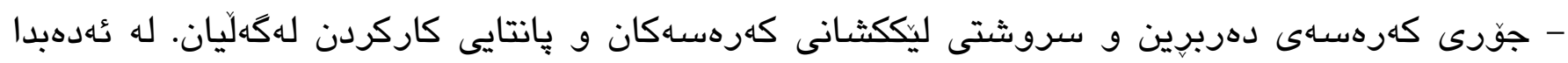

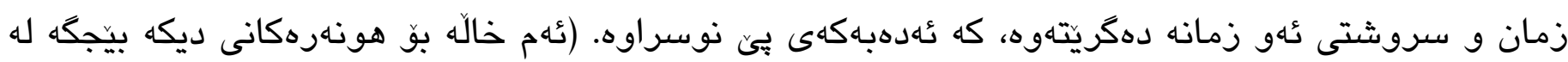
ئهدهب بابهتى عابوريش كارى تيدهكات).

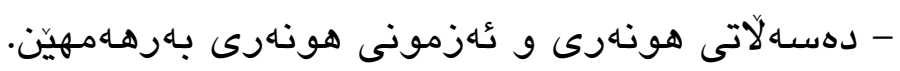
- زهوقى وهركرهكان و تواناى وهركرتنيان.

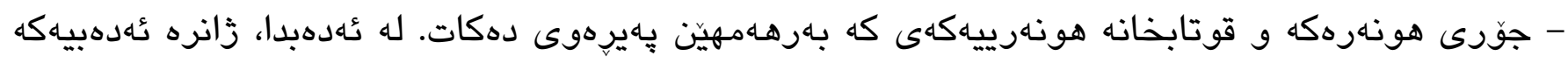
وريّبازه ئهدهبيهكه دهكريتهوه. 


\section{يِيّوهندى نيّوان بلهببون و بلهسكردنى دهرونى و شيّوازى:}

زوقر جار تيّربون رودهدات و بهسبونى دهرونى لاى بهرهامهيّن دروست دهبي، هها ئهكهر بهسبونى

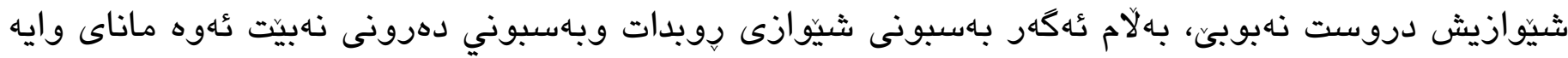

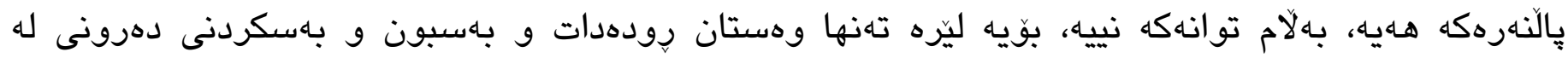

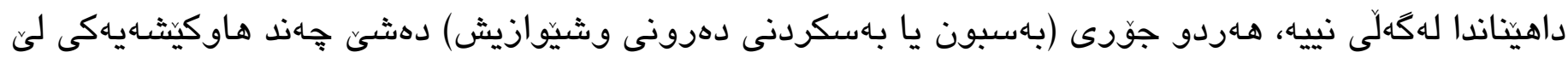

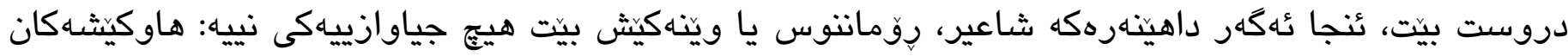
بريتين له:

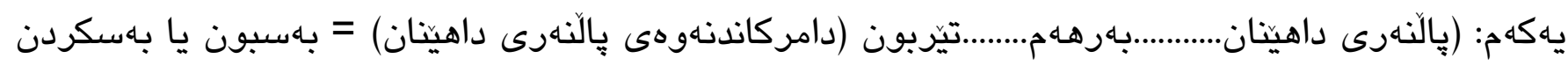

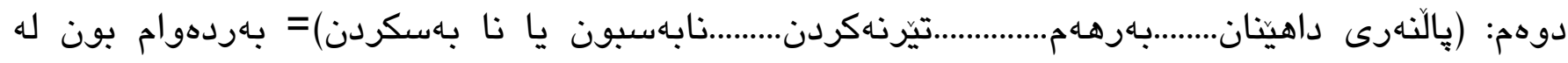

بار هامهينان.

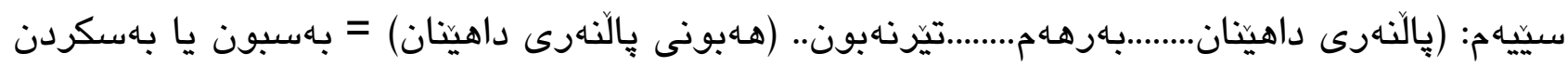

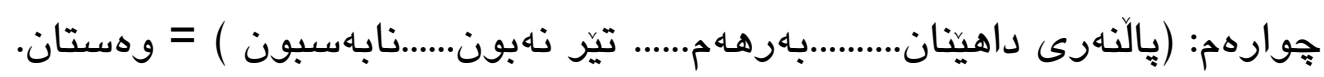

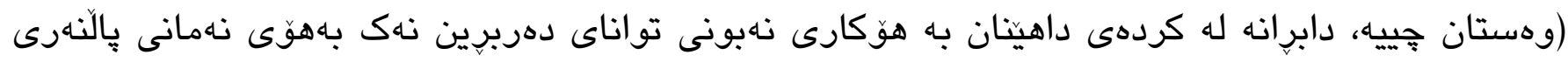

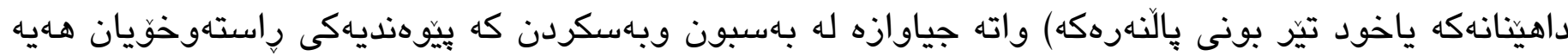
به بِالنهارهكانى داهينان.

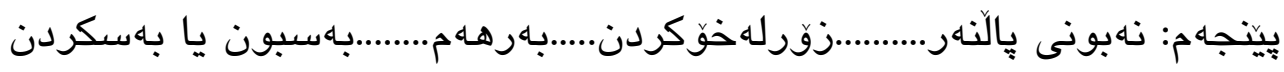

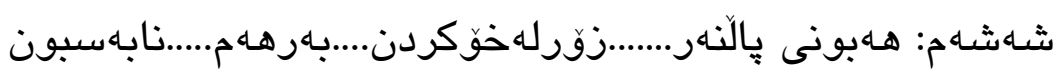

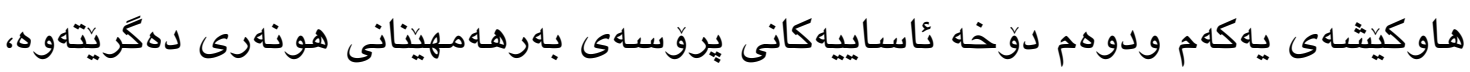

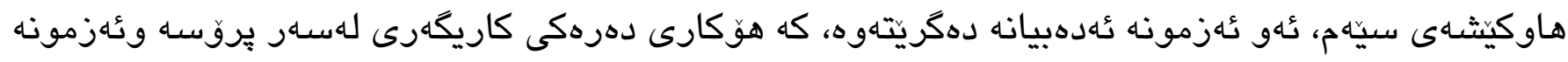

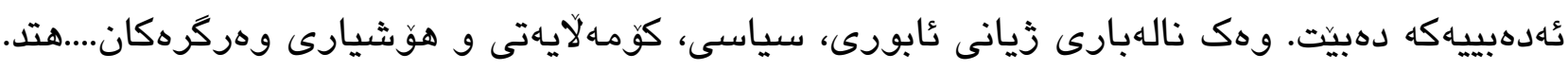

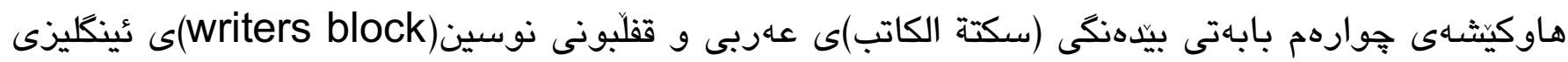

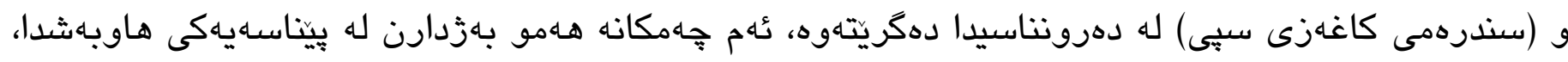

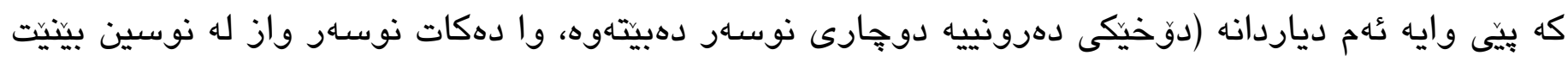

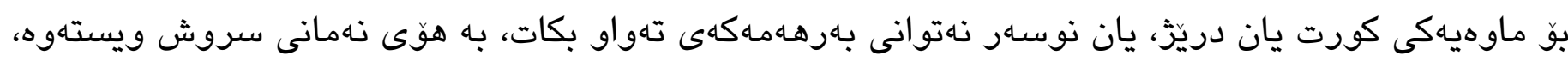

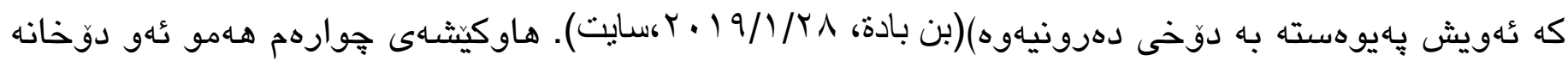

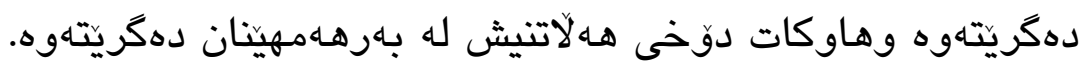

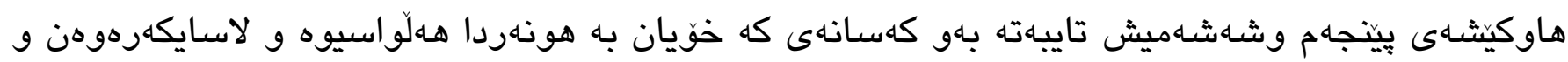

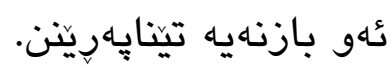

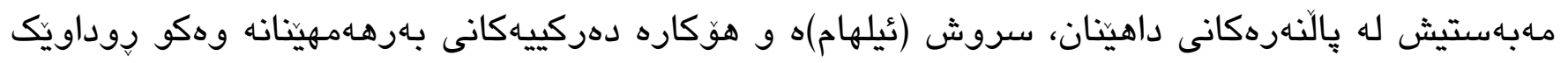

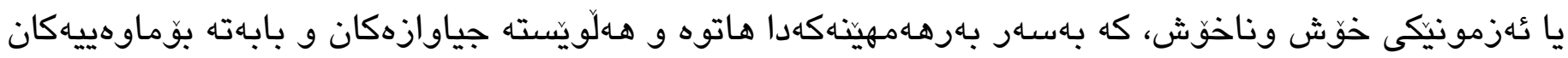




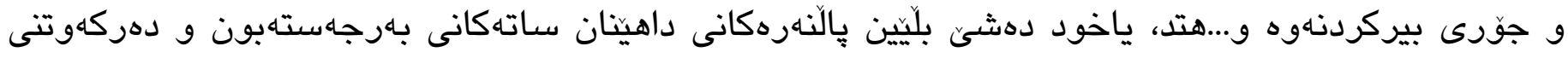
بروسكاكانى نهسته له هـاهتدا، جونكه يِيمان وايه له داهينانى ئهدهبيدا يهكهم هـانكاو له نهستهوه (لاشعور)

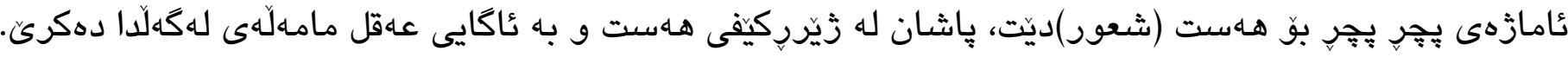

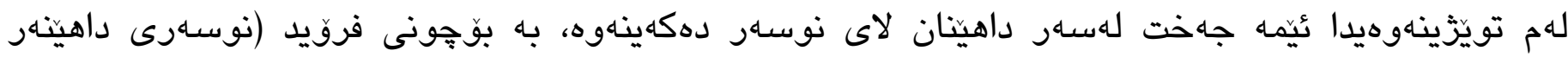
كهسايهتييهكه تارهزو و حهزهانى له نهاتى خوّيدا دهمينيتهوه و بهشيّوهيهك دهريدهبرى و دهيكوّىى تاكو

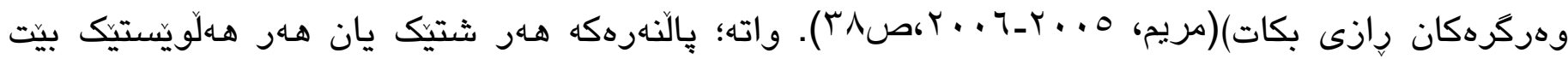

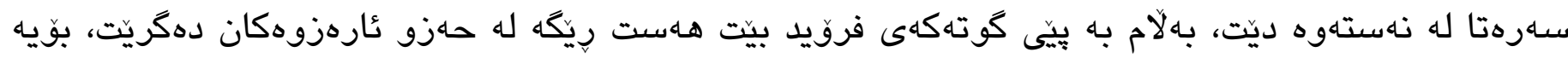

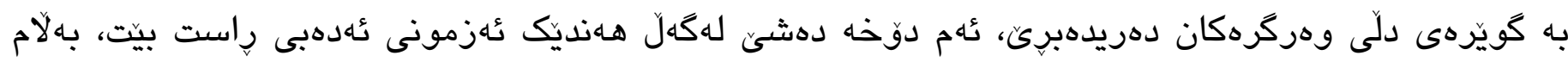

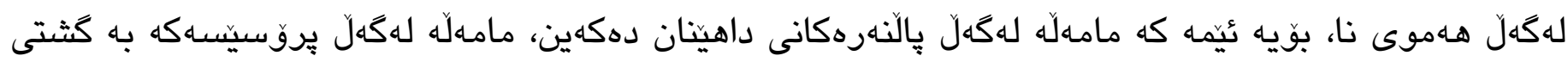

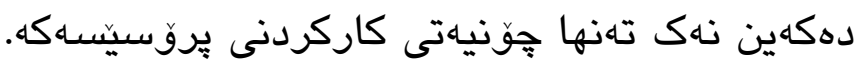

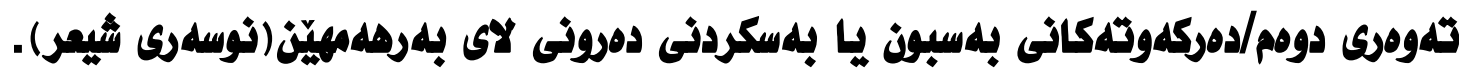

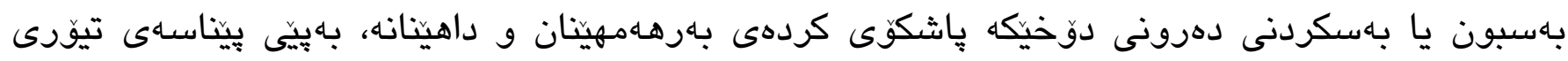

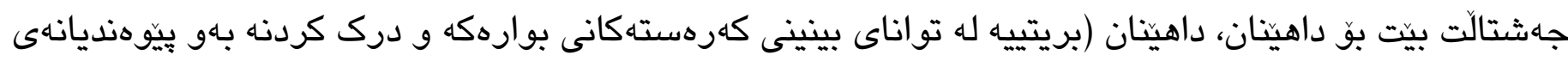

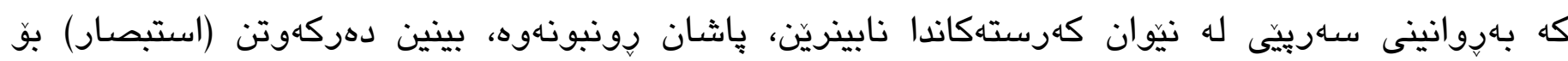

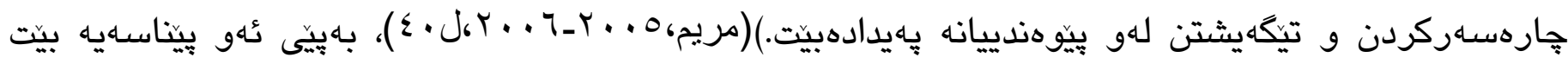

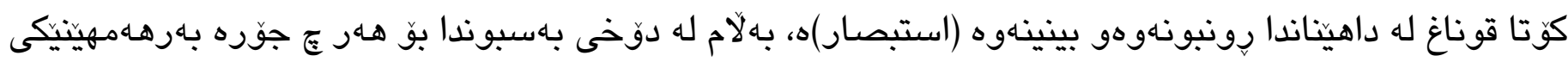

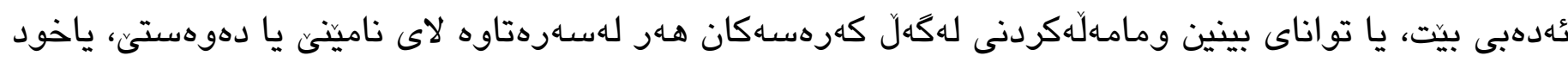
ناكاته قوَناغى روونبونهوه بينين دهركهوتن، بوّيه دوخى بهسبون يابهسكردن يهيدادهبيت، واتا له ئهنجامى

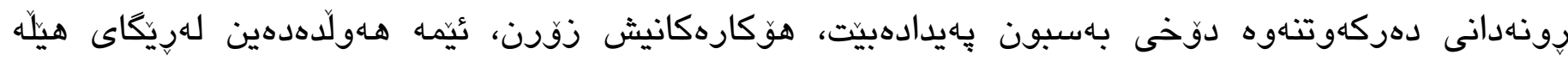
بينراوهكانى يروّسهى ئهدهبى نوسهرهكان دوخى بهسبون يا بهاهكردن له جههند فورميكّى جياوازدارِونبكهينهوه.

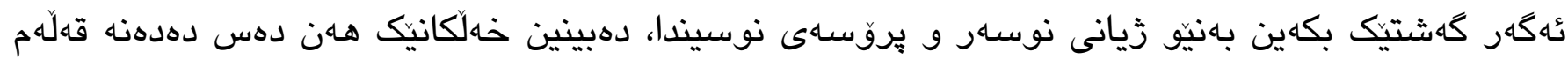

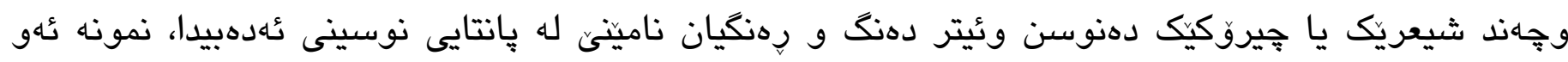

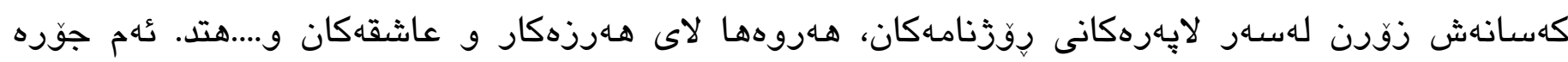

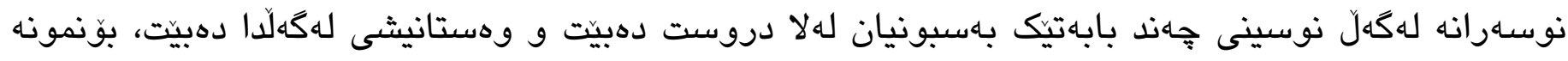

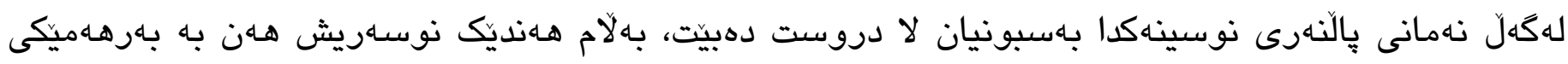

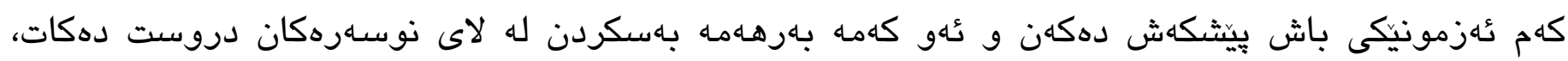

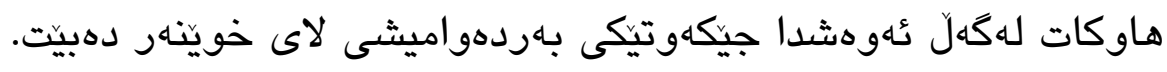

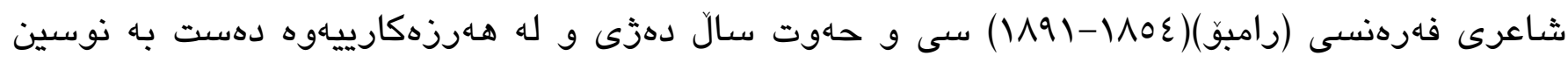

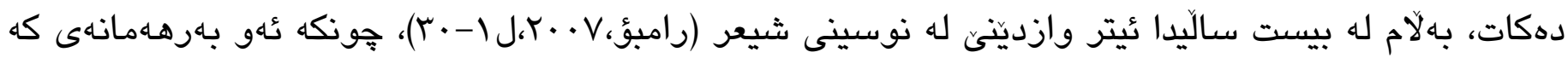




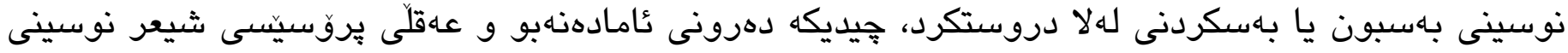

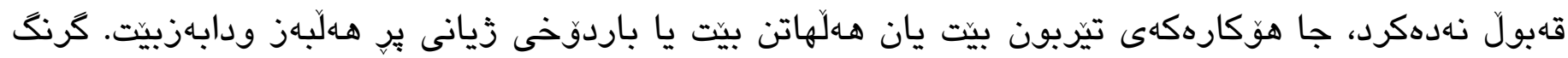

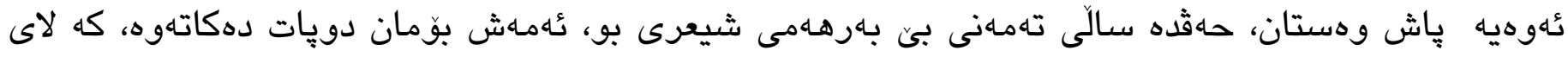

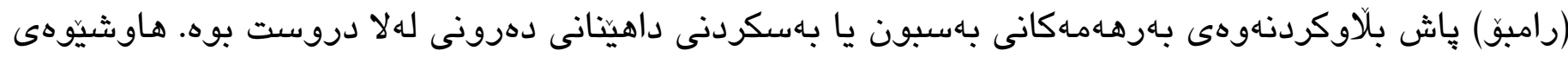

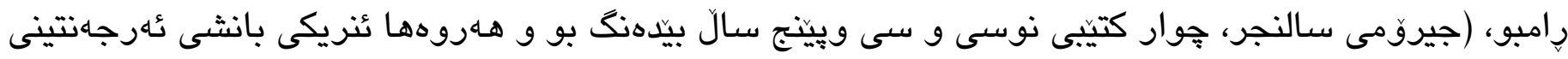

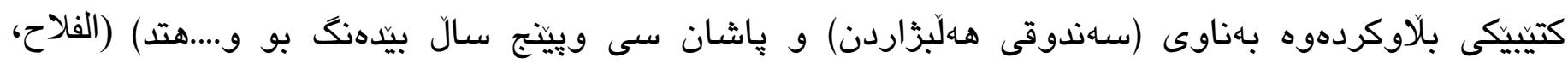

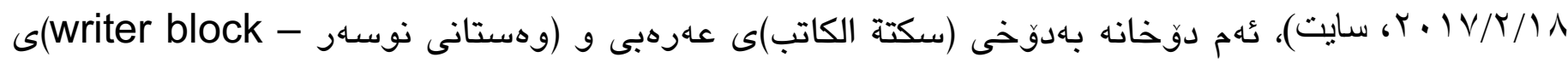

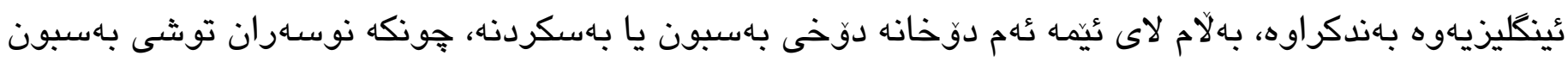
دهبن و هـار ئهوهيه وايان ليداكات نوسين لهلايان بلوّك بكات وبوهستي. له تُكزمونيكى ديكهى ئهدهبيدا شاعرى روسى (سيّركى ياهنين)(1190-1900)، له تهمهنى كورتى زيانيدا و تا كؤا ساتى زيانى بهسبونى داهينانى لا دروست نهبوه، بهلّكاش (جامـهى خوا حافيزييه، كه بهر له مردنى (كوتايى هينان به زيانى) بهناونيشانى (خوات لهكَل برادهر خوات لهكَلّ) نوسيويهتى، كه وهكو بهلكَّى سهالماندنى

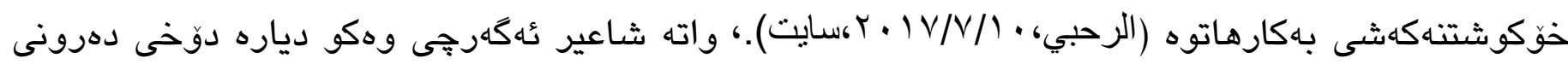

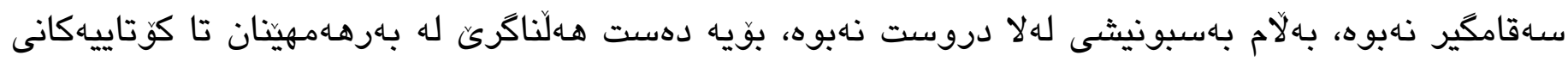

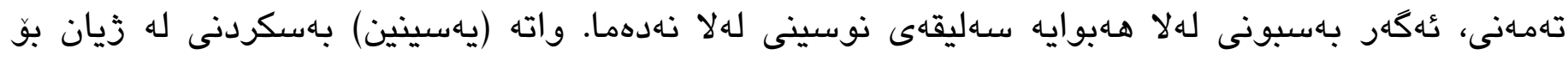
دروست بو و كوتاى به زيانى خوّى هينا، بهلام تا دوا سـات دوخى بهسبونى دهرونى داهينانى لا دروست نهبوه، وهـانا كوتاى زيانى رِوحى تامهزروى دروستكردن بوه. دهيان نمونهى دوخه جياوازهكانى بهسبون يابهسكردن هـان له لايى نوسـارانى ئينگليز و روس و عاهرهب و

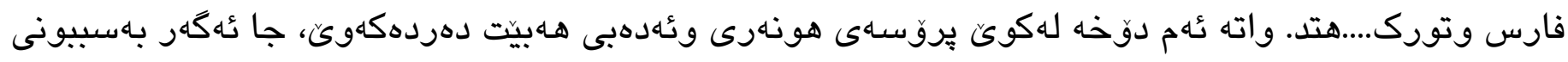
كاتى بيتّ يا هـاهيشـاهيى بيتي، كرنخ تُهوهيه بونى هـاهيه. له ئهدهبياتى كورديشدا، ئهم دوّخه زوّره و هـهنديك جار دوخى بهسبون يا بهسكردن له نيو خودى شيعرى شاعيرهكاندا دركى يَّ كراوه و رِنكى داوهتهوه، بهلاّم به دهربرينى جياواز بوّ نمونه: نالى شـاعير دهلّى:

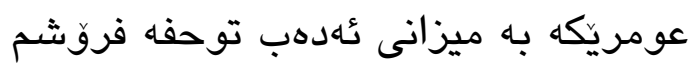

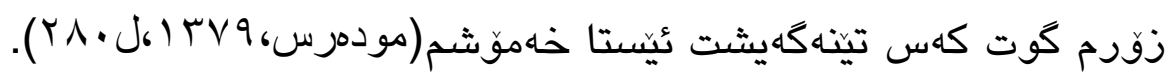

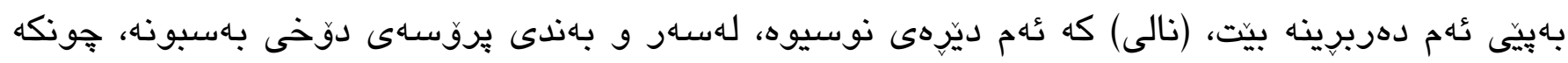

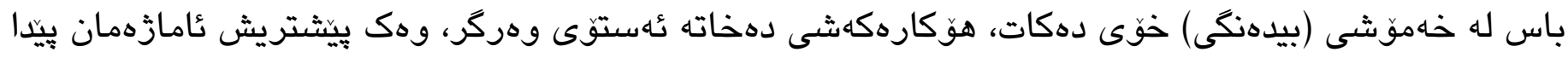

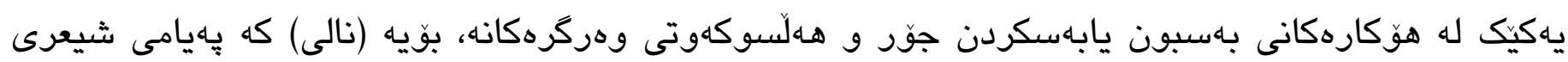
وهكو توحفهى خوّى ناراسته دهكا، لهروىى دهرونييهوه جِاوهريّى وهركرتن وكاردانهوهى وهركرهكانيهتى، كه

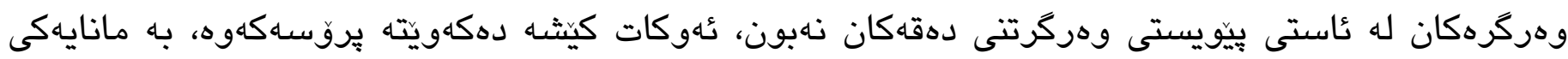


ديكه شاعير تيرناهبوه له بهرهـههينان، بهلاّم به هوَى نهبونى وهركرى يِيّويستهوه بهسبونى لا دروست دهبيّت و

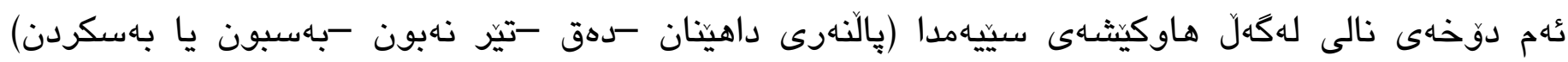

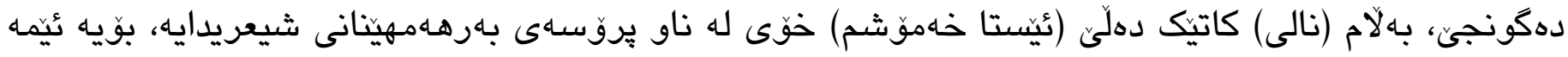

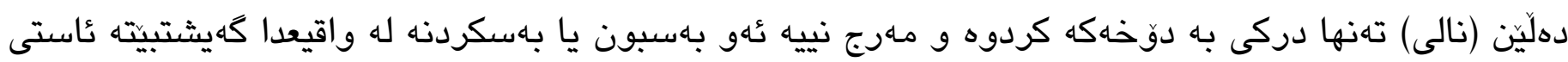
وهستان و دهست هـلكَرتن له بهرهـامهينان، ئهكَر وردهكاريياكانى ئهزمونى نوسينى ناليمان له بـردهست بوايه

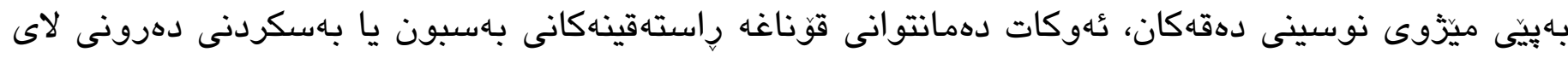
نالى دهستنيشان بكاهين.

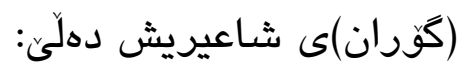

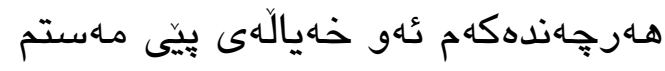

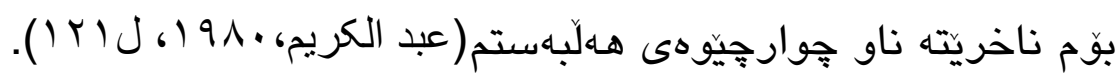
لهم ئهزمونهشدا شـاعير دركى به بهندبونى تواناكانى داهينانى خُّى كردوه، بوّيه دان بهوهدا دهنيت، كه

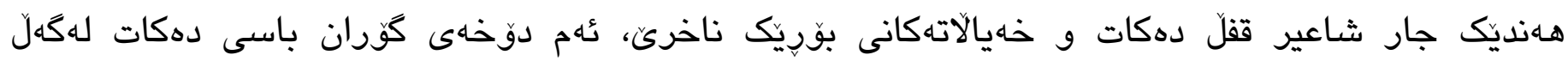

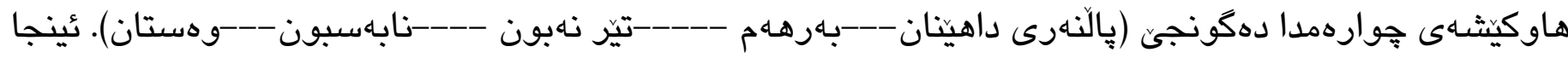

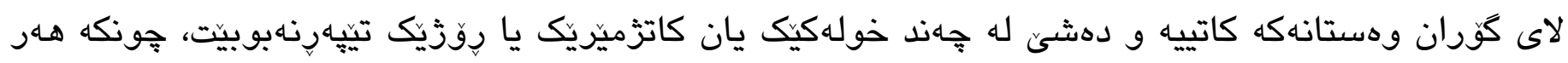

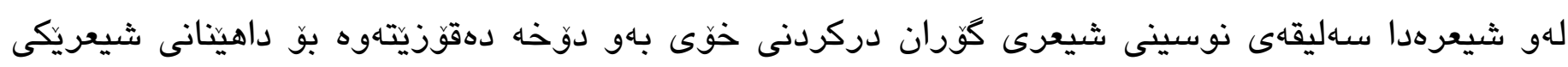
هونهرى جوان.

دوخى به سبون يا بهسكردن يّيوهندى به دريّزى وكورتى شيعرهكانهوه هـيه، بوّنمونه؛ (نالى) كاتيك كه شيعرى (قوربانى توزى ريّكَتم) دهنوسى، نه ديّريّك ونهدوان و نه ده بهسبونى لهلا دروست ناكات، جونكه

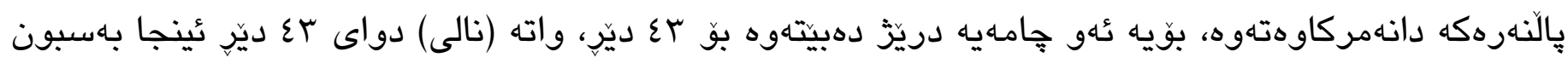

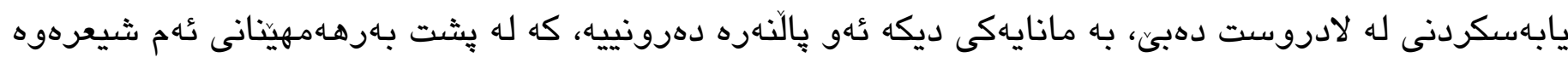

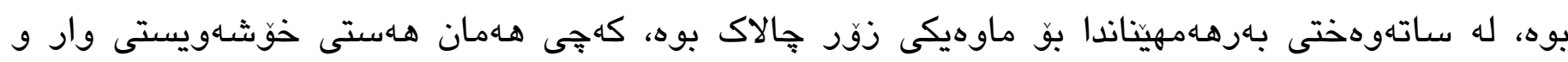

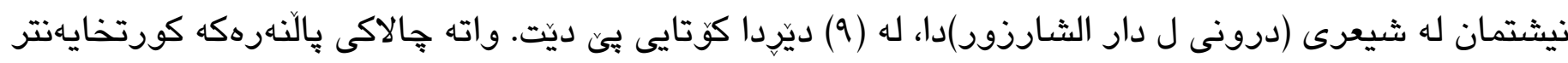

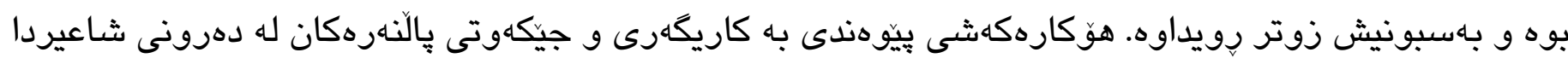
و راستاهيناهبونى سوزيش له سـاتى بهرهـهـينّاندا هـهيه.

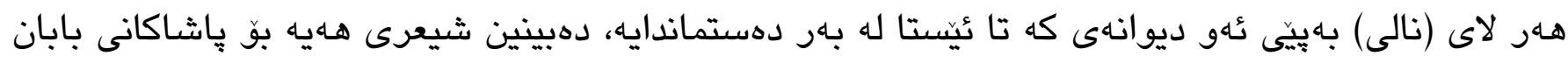

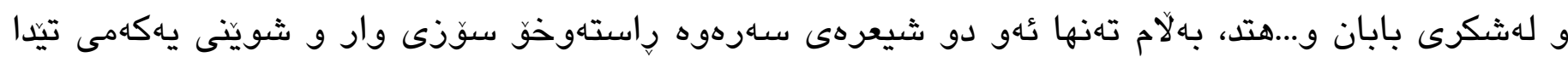
دهركهوتوه، واته لهم بابهتهدا ثٔهو دو شيعرهى بونهته هوَى پِهيدابونى بهسبون يابهسكردنى دهرونى، كهيى هـامان سوّزى نيشتمان و وارو كَهرانهوه بوّ شويّنى يهكهم لاى حاجى قادرى كوّيى، له جههندين شيعردا بـه

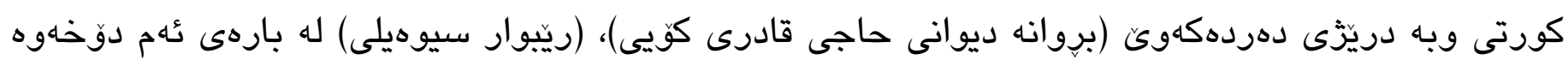

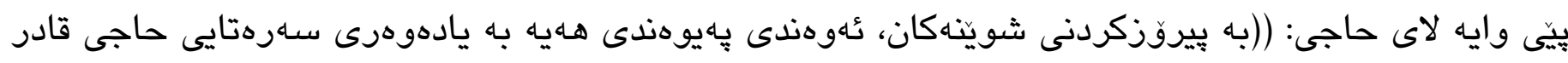




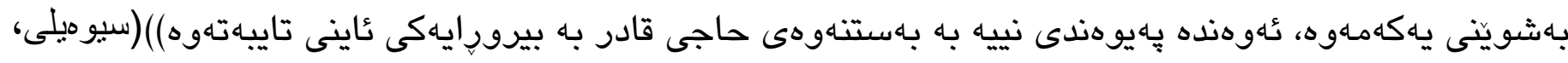

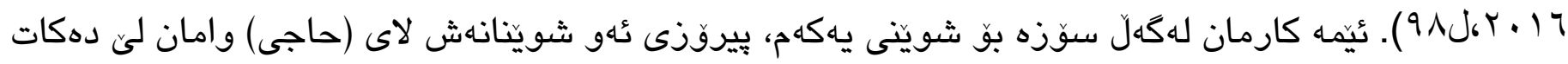

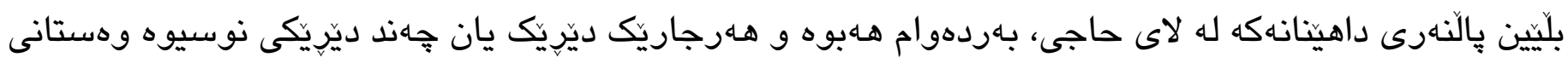

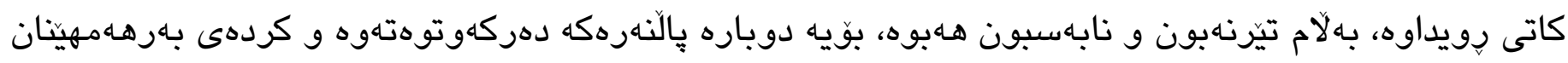
و كَران به دواى بهسبون يا بهسكردنهكه دوبارهبوتهوه. لهم بابهتهدا دوخهكهى (نالى) لهكهل هاوكيثـى

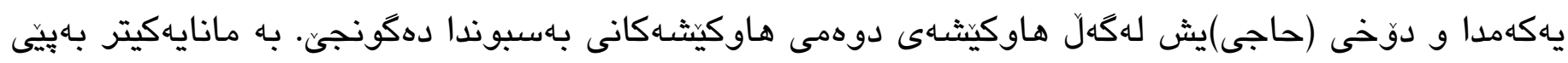
دوخه شيعرييهكان بيت، مانهوهى (نالى) له بازنهى دهركهوتهكانى سوزى وار سـابارهت به بهرهـهمينانهوه

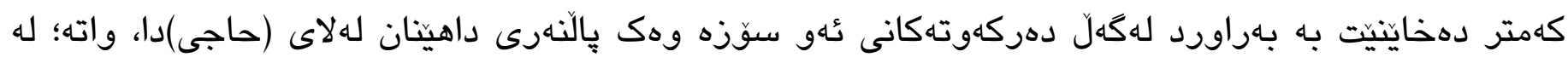
كُهزمونى ثيعرى ناليدا بابهتى وار بهشيّوهيهكى بهرجهاهته و راستهوخق له جههند تاقيكردنهوهيهكى كهمدا

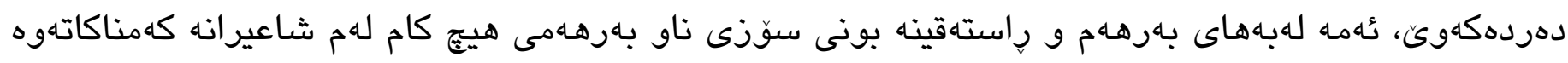

يا زيادناكات، ئهمه تهنها دوخى كردهى داهينان لهم بوارهدا و لاى دو شاعير شروقه دهكا.

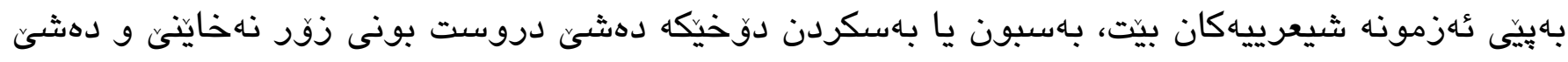
كاتيكى زورىى ييّويست بيّت، هونهرى (جوارين وتاك بهيت) يهكيكه له و ثُهزمونه شيعريانهى كه بهسبون يا

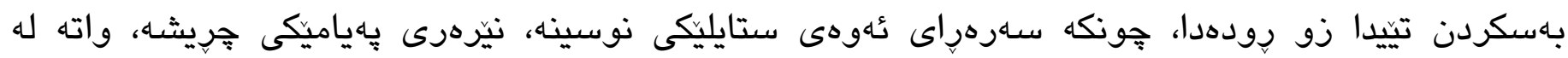
جواريندا ئهو بروسكه هزرى و ويّنهييانهى له نهستهوه دهنيّردرين كورت و خيّران، بوّيه بهسبونهكه زو زو

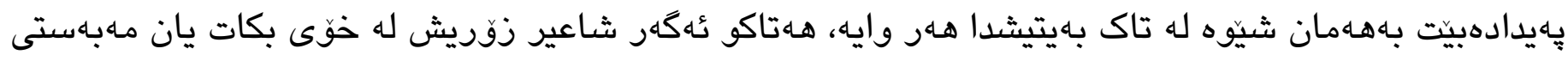

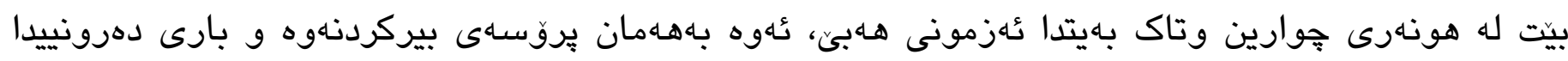
تيّيهر دهبيت، جياوازييهكهى تهنها لهراستهقينه بون و رهسهنايهتى بهرهـمـكهدايه، واته؛ كردهى بهرهـهـيزنانى جوارين يان تاك بهيت لهو كردانهيه كه بهرهـههيّن زو دهكاته دوخى بهسبون يا بهاهكردن، جونكه مانهوهى

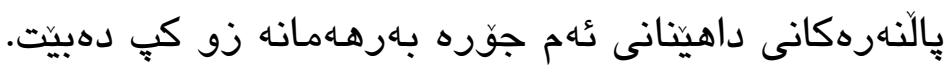
يـكيكى تر له دوخهكانى بهسبون يا بهسكردن له شيعرى داشوّريندا بهرجاودهكهوي، شيعرى داشوّرين،

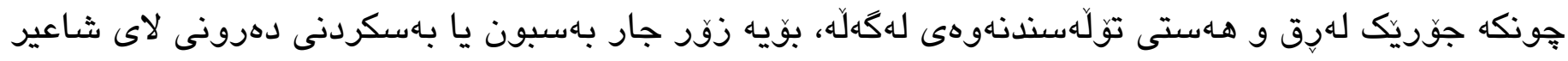

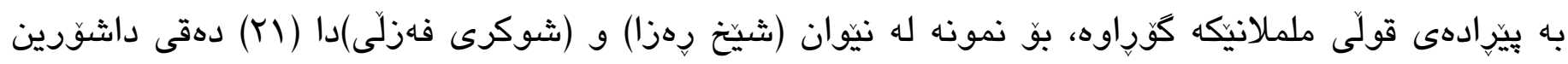

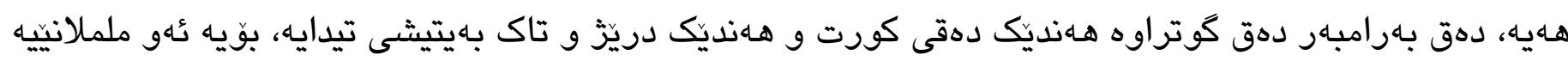
هـنديَك جار له تاك بهيتيكدا بهسبون يا بهسكردنى له لاى شـاعير دروستكردوه و هـهنديك جاريش تا يهكتريان

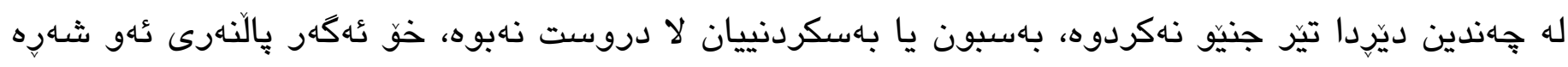

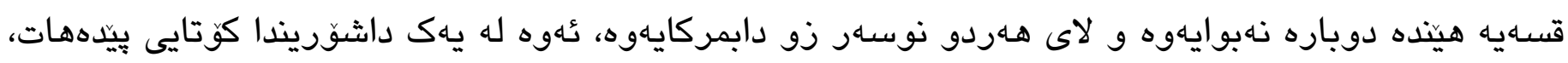

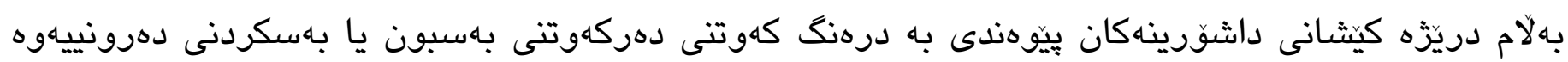




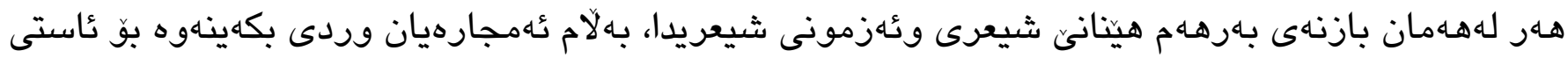

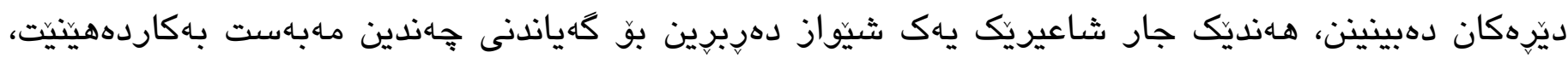

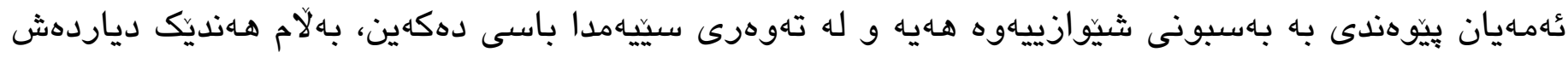

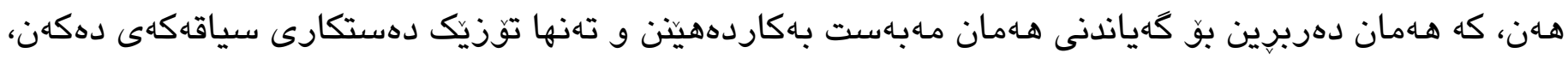

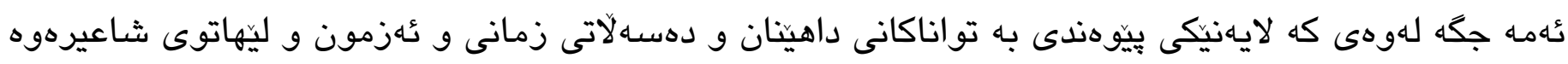

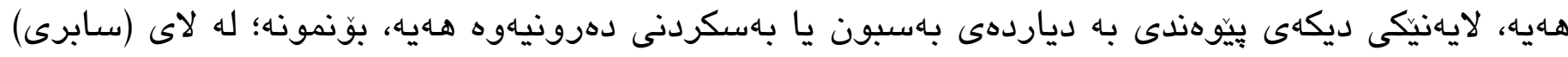
شـاعير، وشـى (عهناب) له جههندين شوينّا دوباربوهتهوه،(د.كازاد باخهوان) له شيكردنهوهى ئهم دوخهدا سيى

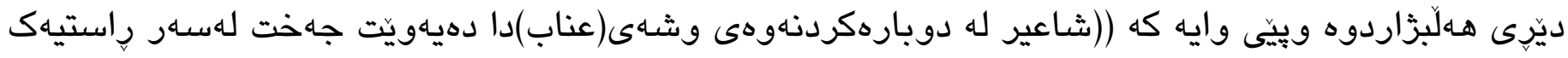

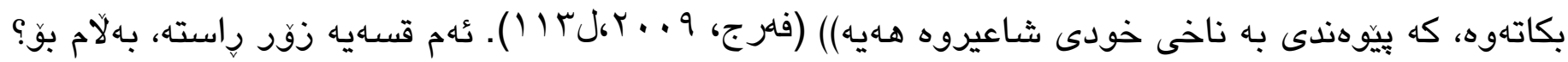
شيعرهكان بريتين له: -تيّدها بوّ لهرز وتا -عناب-ى ليّوشافييه بوّيه ليّوى خُوى كَزيوه دهست و يِهنجهى وادهكا -جومـه كن نهوعيّ -اطبا-بوّ عيلاجى لهرز وتا جمله فهرمويان هـر(عناب)ه دهفعى تا دهكا - عاشق وغامبار و جاوت شـهراب

خهستهم وتادارم و ليّوت عناب(فهرج، 9 . . rك، وس ( ) ).

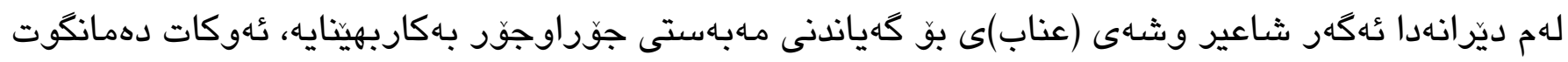

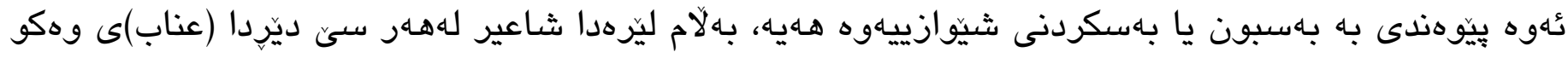

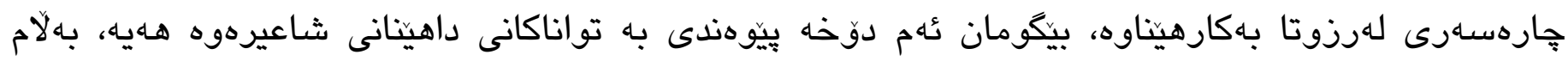
هـاهونى ئهم دوخه شيّوازييه تهنها ييّوهندى به شيّوازهوه نييه، ييوهندى به لايهنى دهرونى شاعيرهوه هـهيه، جونكه ثـاعير كه بيروّكهى بهكارهينانى عهنابى بوّديت له يهكهم بهكارهينانهوه بهسبون يا بـاهكردنى دهرونى لا دروست ناكات، بوّيه دوباره و سيّ بارهى دهكاتهوه، خُّ عُكگهر لهيهكهم بهكارهينانهوه بهسبون يابهسكردنى لا دروست بكردايه، سـليقهى دوباره بـكارهينانهوهى نهدهبو، بهلاّم شاعير هينده لهزيّر ركيّفى بيروكهكه بوه و جيزّى ليّينيوه، بوّيه به سيى دهركهوته ئينجا بهسبون يا باسكردنى لادروست بوه، واته قسهكهى (.ئازاد باخهوان)

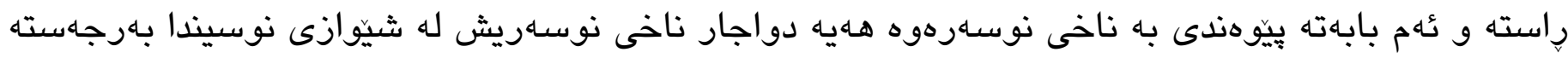

له تهوهرى يـكمدا ئامازهمان باهوه كرد كه بهسبون يا بهسكردنى دهرونى داهينان دهشيى دو دوّخ دروست

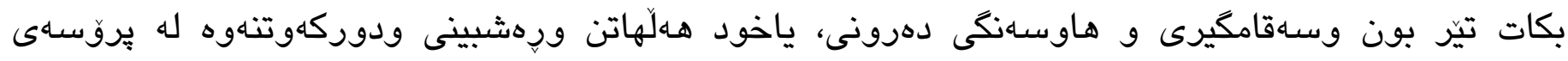

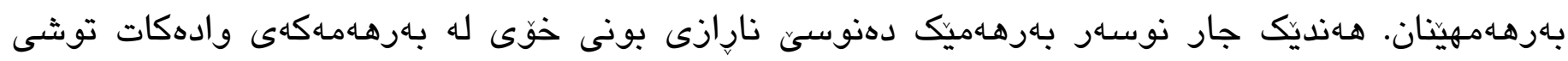




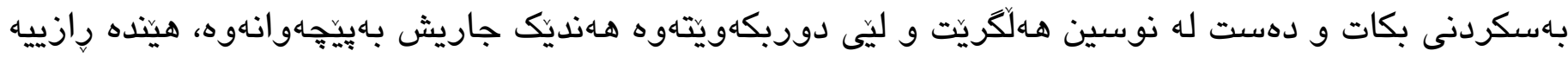
له باهرهـامـكهى بهسكردنى لادروست دهكات و وهستانى هـاميشـيهى لا دروست دهبيت. بوّ نمونه:

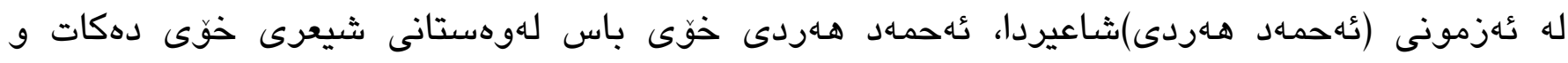

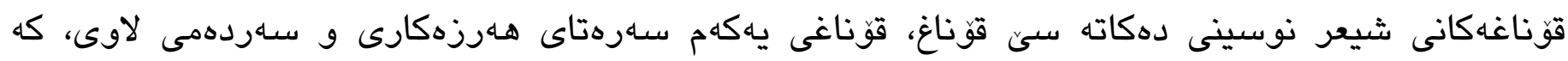

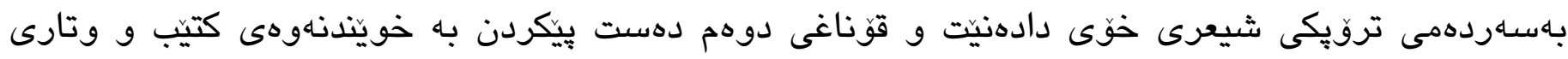

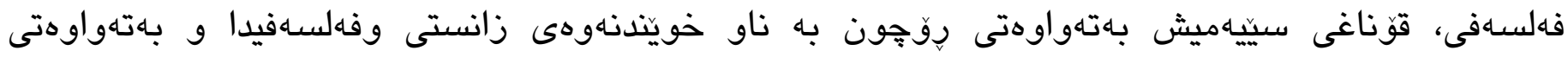

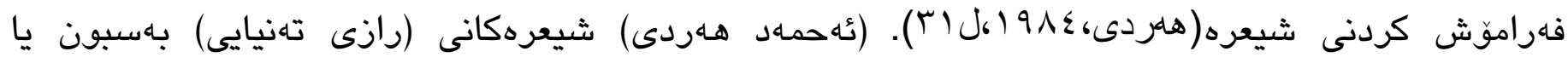

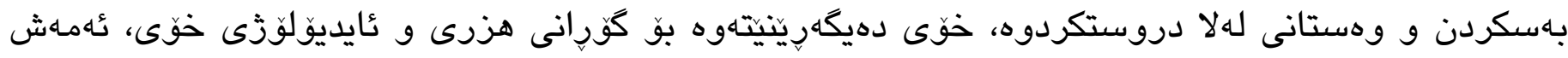

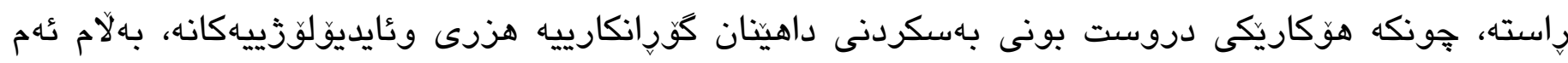

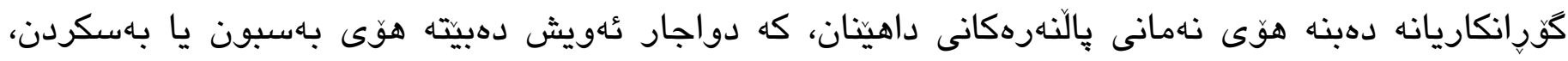
ياخود (رازى تهنيايى) توانى پِالنهرهكانى داهينان لاى شاعير دابمركينيتهوه، بوّيه بـسبون يا بهسكردن دروست

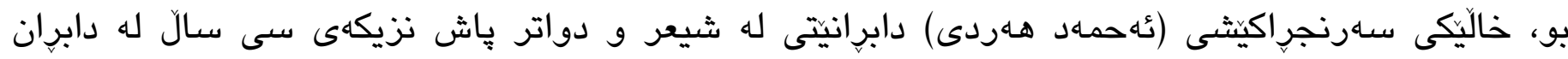
تهواوكردنى سىى شيعرى ناتهواوه، له بارهى تهواوكردنى ثئه شيعرانهوه شاعير دهلّيّ: ((بهليّنيشم دابو

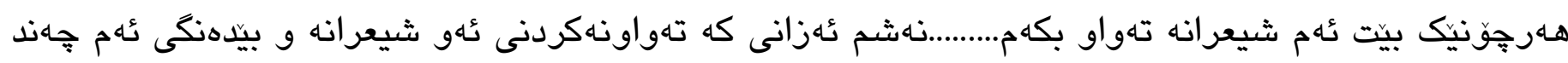

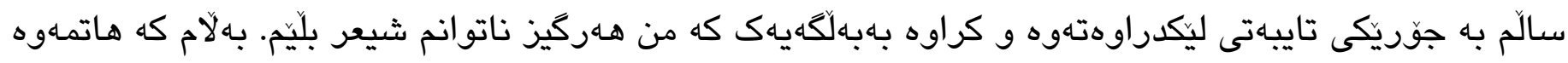

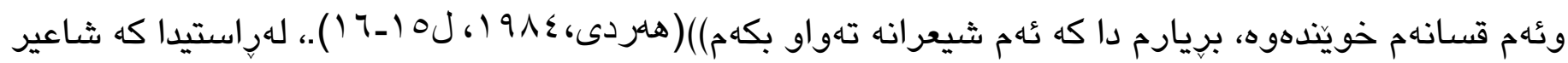

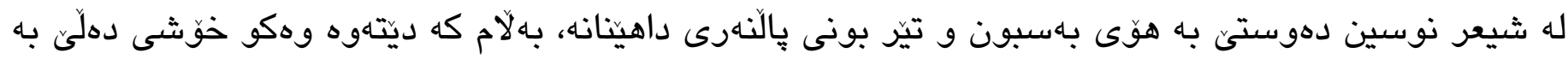

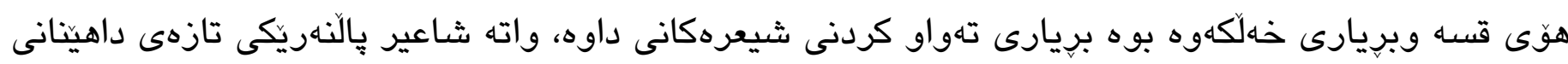

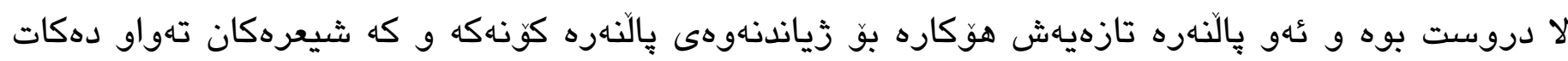

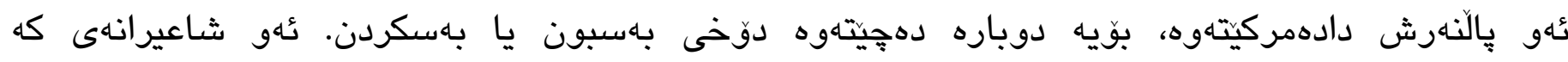

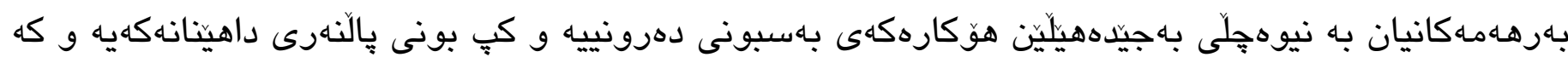

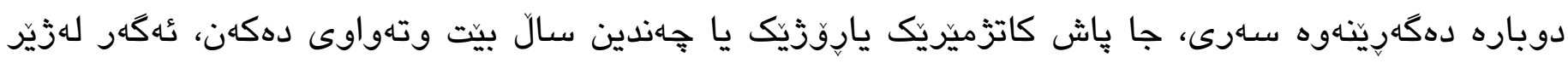

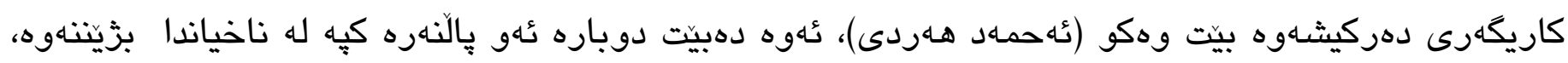

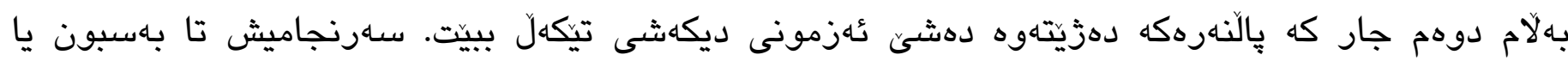
بهاهردنزيو نهات كوّايى يَّ نايهات.

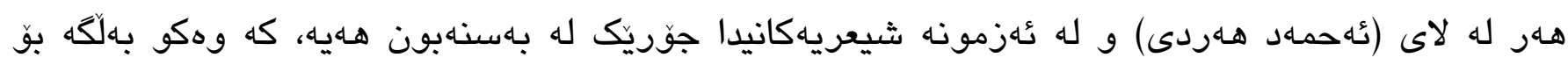
يشتراستكردنهوهى جههمكى بهسبون بهكاريدينين، ثُهويش شيعرى (ست فاتمه) و (دو جهاشن دلّارى)يه، شاعير

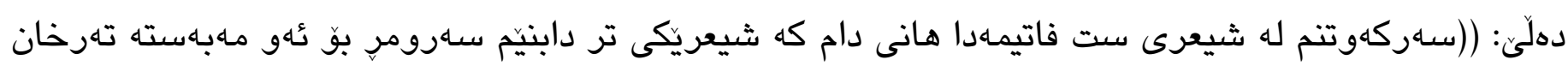

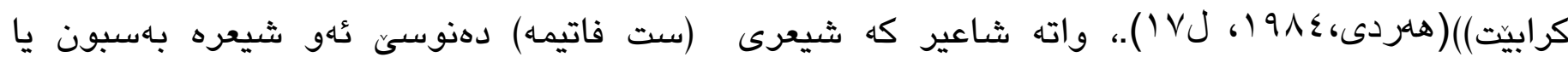
باهكردنى دهرونى له داهينان لهلا دروستناكا و ئهو جِيّزهى كه كردهى بهرهـهمينانهكه به شاعيرى بهخشيوه 


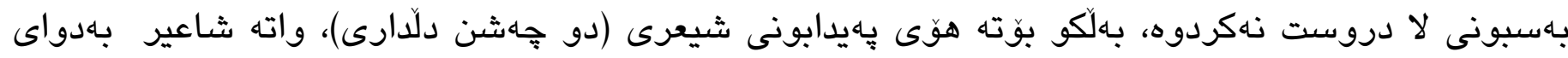
كَهيشتن به تيّربون و بهسبوندا دوباره بـاهرهام دروستدهاتهوه.

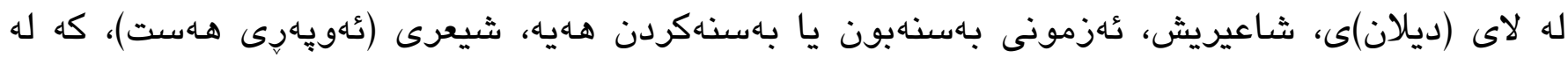

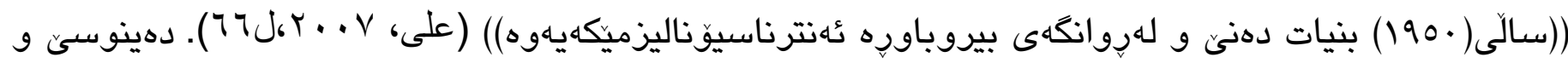

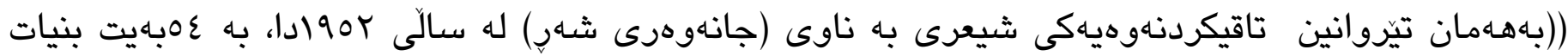

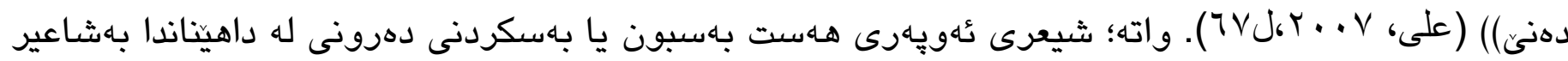

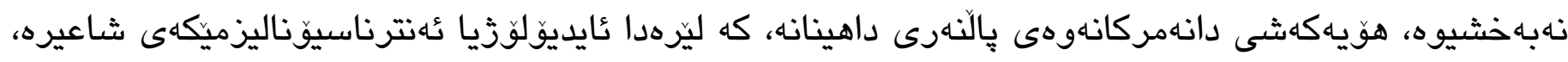
بوّيه ئهيش له دواى دوسال له هـهان بازنهى ئهزموندا بهرهـهى نوىّ دروست دهكات.

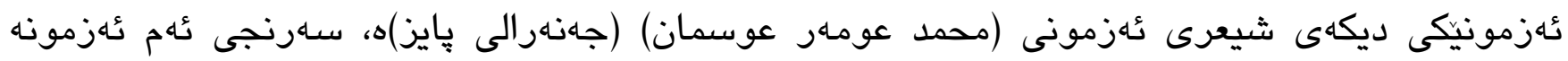
شيعرييه بدهين، دهبينين تهنها ديوانى (له غوربهتا)بهسبون يا بهسكردن لهلاى شاعير دروستدهكات، ئهو تيريونهى ثئو ديوانه به شاعيرى بهخشى تا كوتاى زيانى شاعير بهشى كردوه و بهسبونى دهرونى بو

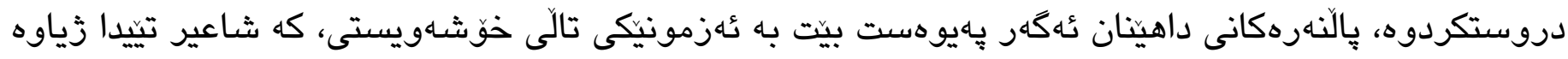

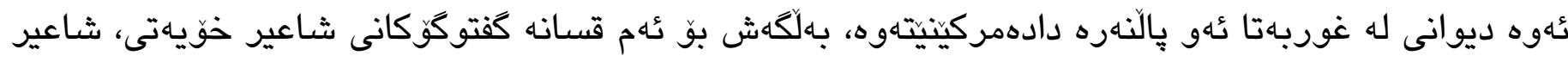

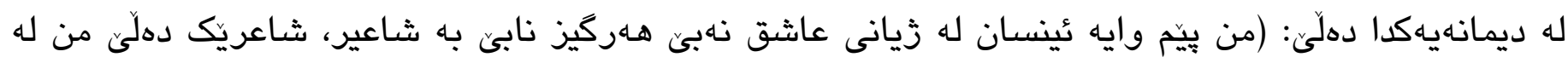

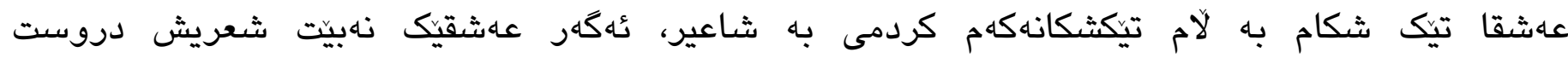

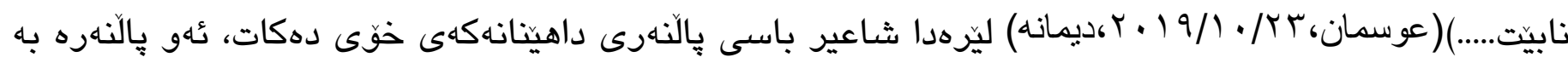

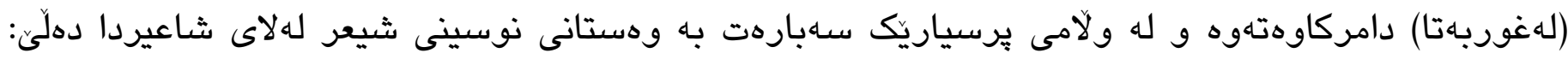
(من له شيعرا لهكَلّرهنكدا تهعامولم كردوه، كَلآى زهرد سهوزى كهمتر تيدايه. ئهو سهردهمانهش سياسهات بو

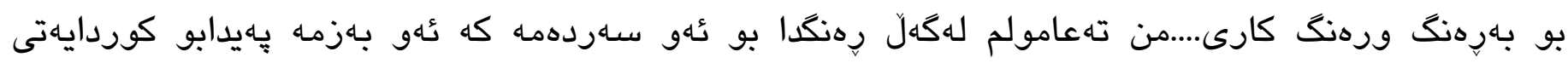

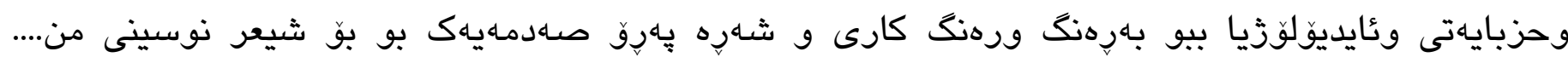
هـاميشـه شئيمانم بهوه بوه، دهلّي: كوّيلهيه شيعر بنوسى به مـهنا شيعر بيت، باشتره لهوهى ده ديوان شيعرى

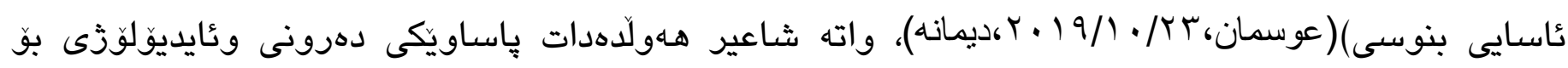
وهستانى داهينانه شيعرييهكهى بلدوزيتاهوه و دواتر رِونتر قسه دهكات و قهناعهتى خوّى بهو ديوانه شيعره و بهاهاى تُهو ديوانه شيعره باس دهكات، واته دهرونى شـاعير ئامادهيى داهينانى شيعرى تيّا نييه، جونكه يِيّش وهخته بريارى لهسهار داوه، كه يِيويستى يحى نييه و له نهستدا ئهم برِياره كوكاكراوه، بوّيه له دواى ئهو ديوانه

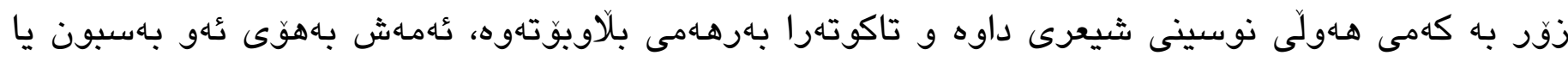

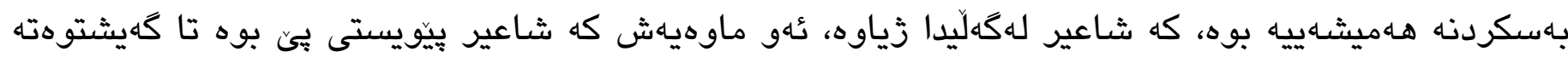

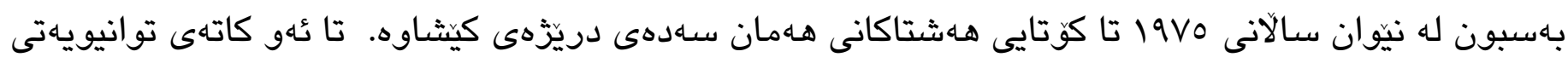

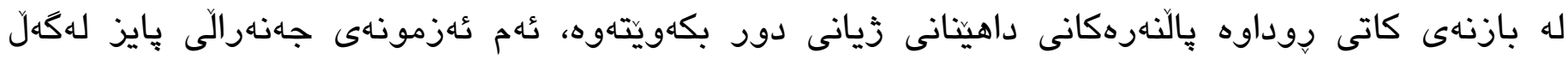




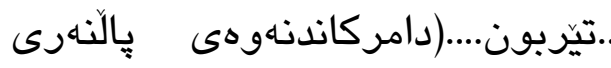

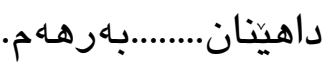

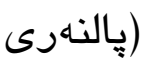

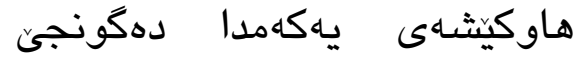
داهينان)......باهبون يا بهسكرن). هوكاريّكى ديكهى بهسبون يا بهسكردنى دهرونى له داهيناندا يِيّوهندى به نهبونى كهناليّكه بوّ بلاّوبونهوهى

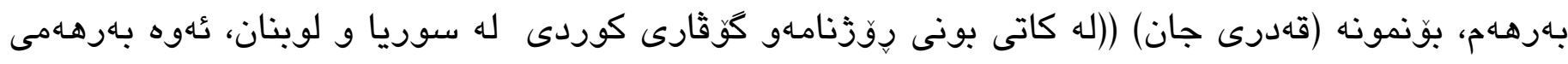

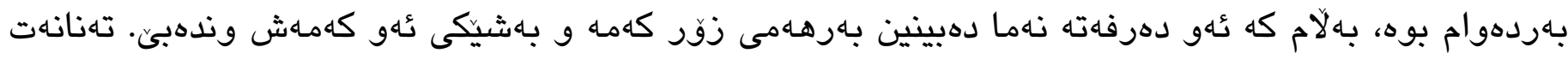

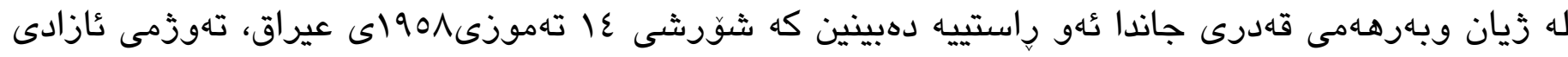

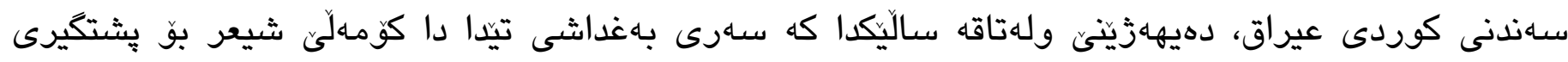

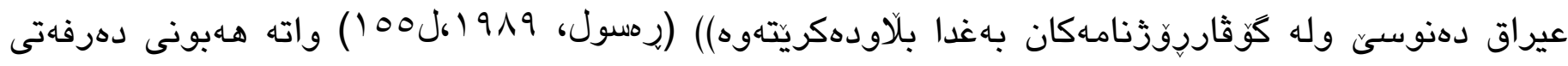
بلاّوبونهوه وروداوه سياسيهكان پِالَّرهى شيعر نوسين بونه و بهنهمانيان بهسبون يا بهسكردنى داهينان

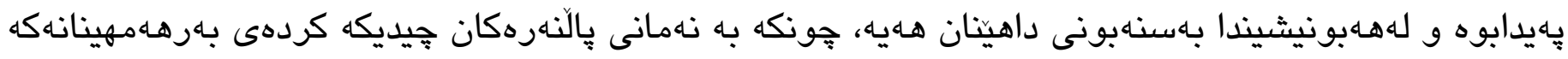

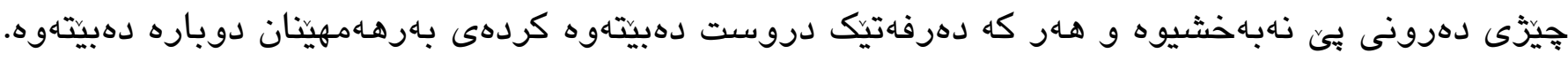
دياردهى بهسبون يا بهسكردن و دهركهوتهكانى له ثـزمونى شاعيراندا دهكريّ بو هـهر شاعيريك به جيا

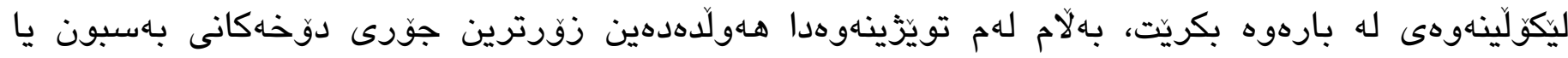
بهاهكردن وباهناهبونى داهينانى له لاي نوسـره جياوازهان بخهينهرو.

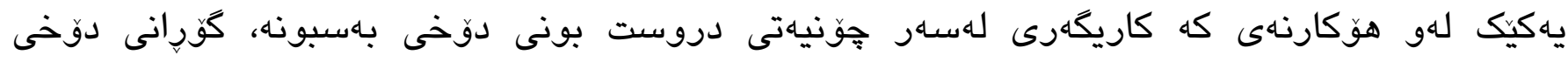

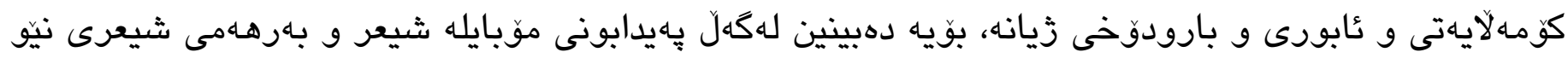
سوشيال ميديا، دوخى بـاسبونيش له لاى نوسـاهان زوتر دروست دهييت، هوكارى يهكهمى ئهم بابهتهش زو بلاّوبونهوهى بـرهـمـكانه و زو وهركرتنهوهى ولاّمدانهوهى وهركرهكانه ئهم جوّره بهسبون يا بهاهكردنه

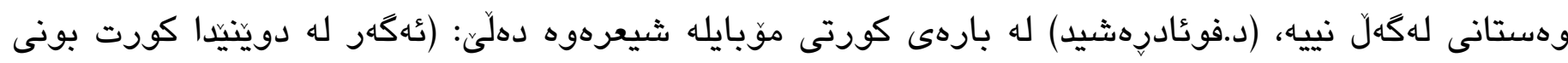

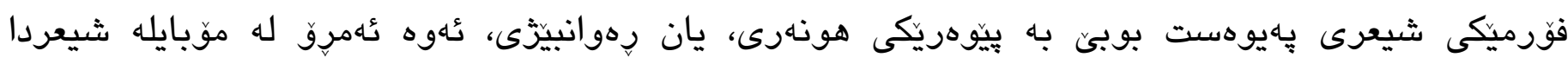

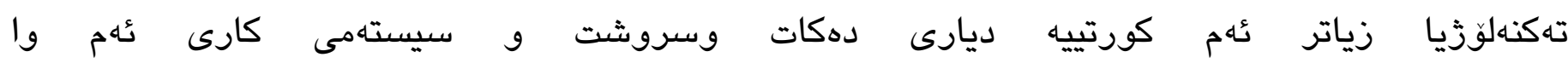

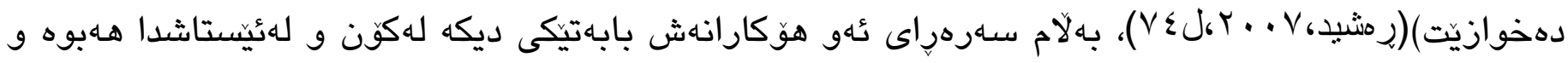

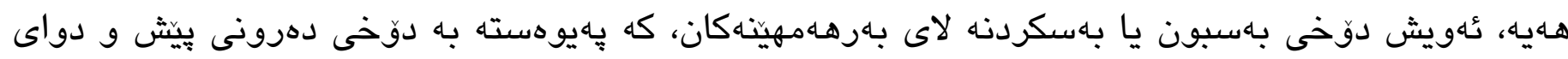

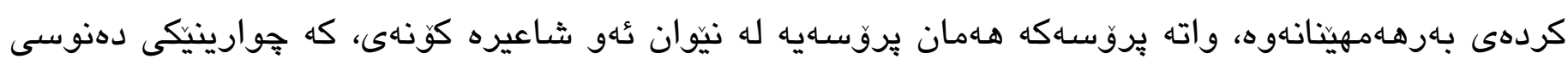

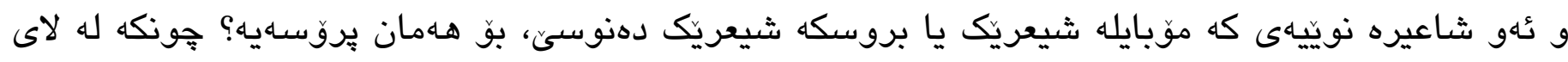
هـردوكيان كهيشتن به دوخى بهسبونى دهرونى له داهيناندا كردهيهكى كهم خايهنه، جياوازييهكهى للهوهدايه،

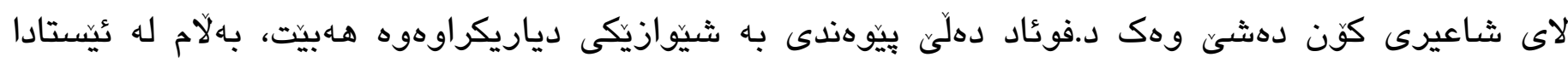

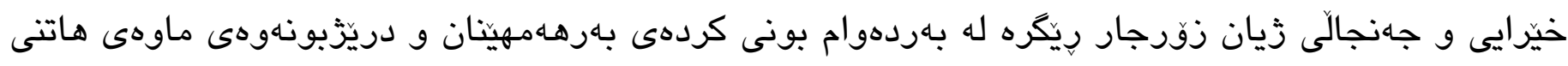
ئيلهام، ياخود نهمانى دهرفهت بوّ نهست (لاشعور) تاكو به ئارهزوى خِّى بروسكهكانى بوّ هـست (شعور)

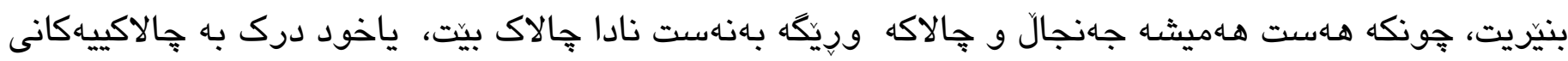




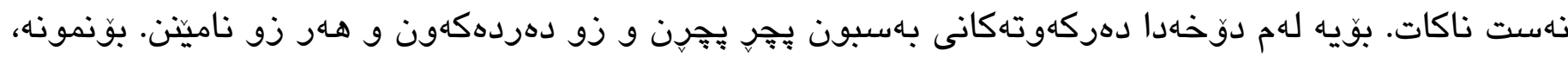

$$
\begin{aligned}
& \text { بورهان ثٔهمـهد له بروسكاهيهى شيعريدا دهلّي: } \\
& \text { له كوزراويَكهوه بوّ كولهيهكى ويَّلْ }
\end{aligned}
$$

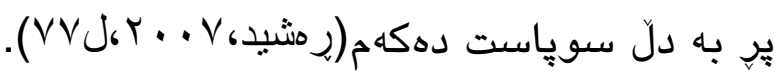

لله بروسكهيهدا شـاعير سيى بابهتى فراوان وقول، كه (مردن و جارهنوس و دوخى دواى مردن)ه، له يهك

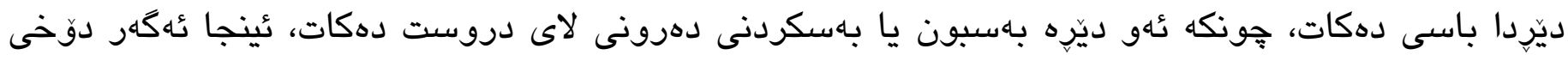

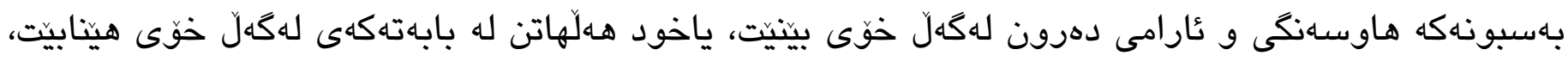

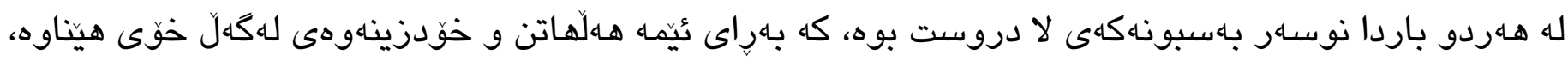

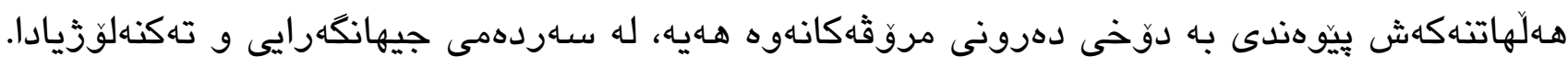

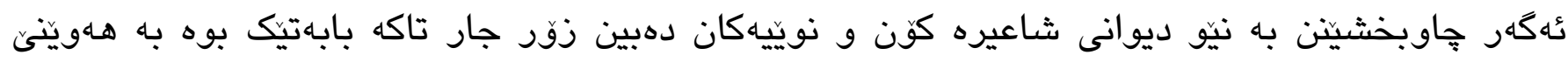
دروست بونى جهندين شيعر، ياخود بابهتيك تهنها بوه به هـهينى يهيدابونى تاكه شيعريّك وئيتر هيج

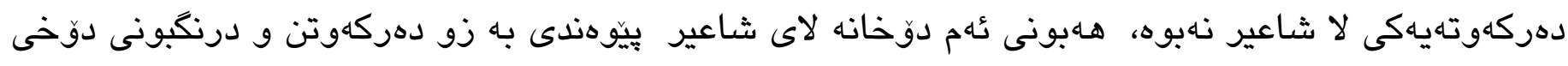
بهسبونه، بوّنمونه، (وهلى ديّوانه)ى شاعير، بهاشى هـره زورىى شيعرهكانى له بازنهى كاريكُهرييهكانى (ثهام)

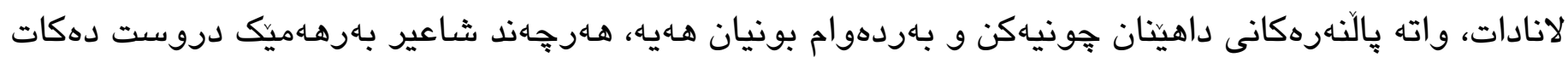

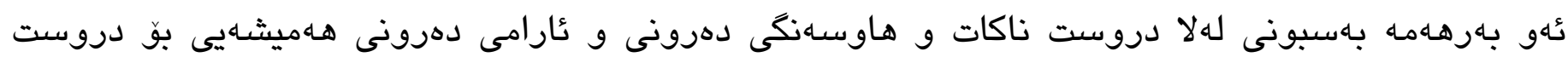

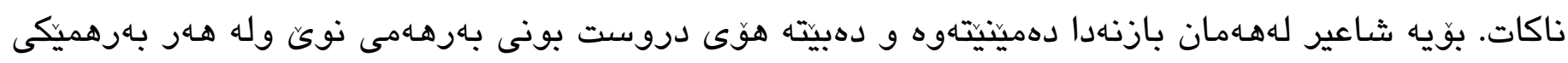

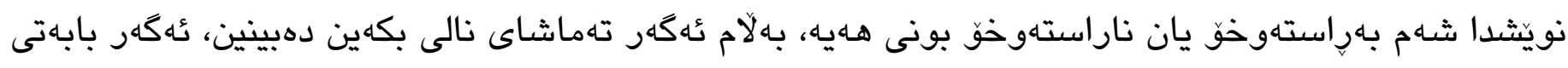

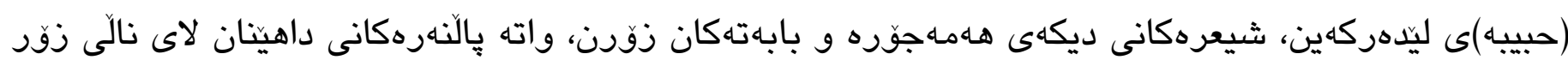
بوه، هـار جار له بابهتيكدا شيعريكى نوسيوه و كه لهو بابهتهدا بهسبونى بو دروست بوه، سـليقهى شيعرى و

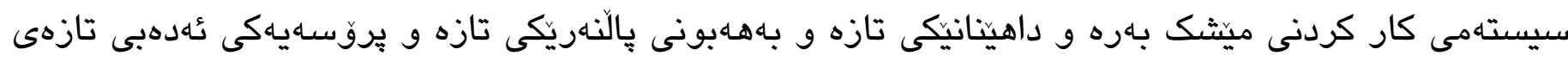

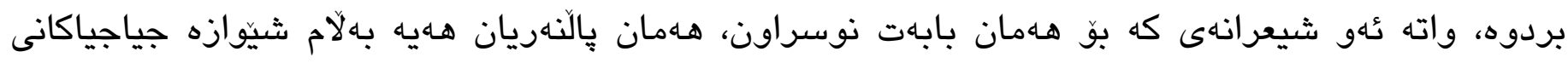

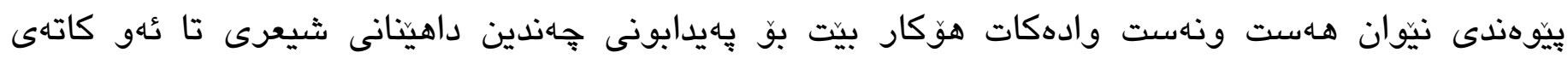

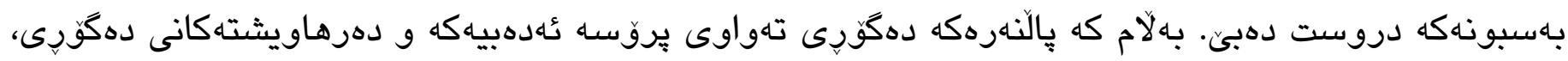

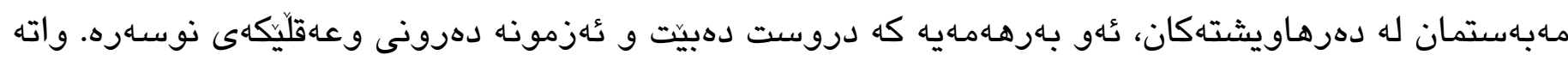

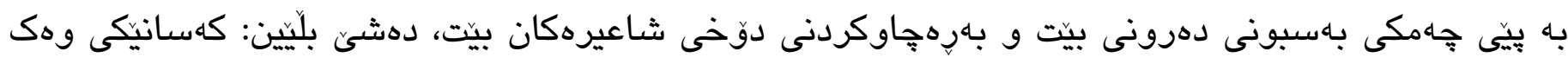
(وهلى ديوانه، محمد عومهر عوسمان، ئهمـهد هـردى وجههندانى تر) شيعر له لايان ميّوانيكى يِيروز وبههادار

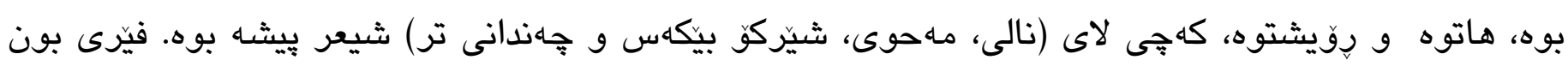
و لهكهلِيان ماوهتهوه.

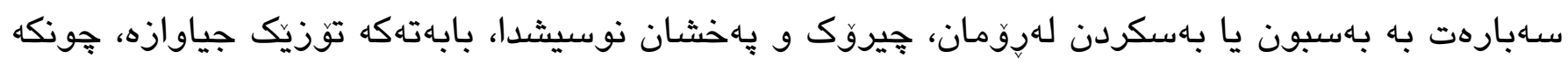

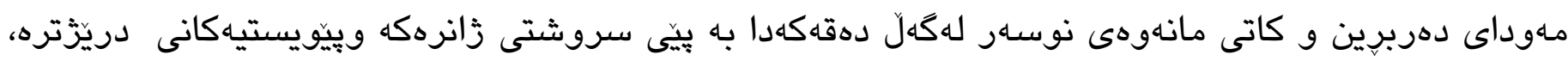




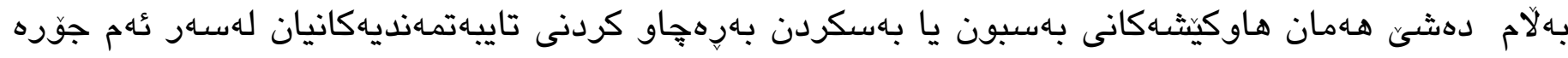
ئهدبيانه يِراكتيك بكريّ، بوّ يِراكتيك كردنيشى بيّويسته هـهو وردهكارى دياردهكانى ئهو هونهره ئهدهبيانه لهبهر

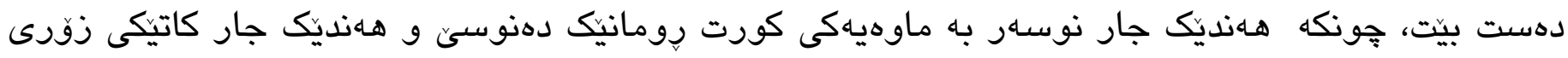

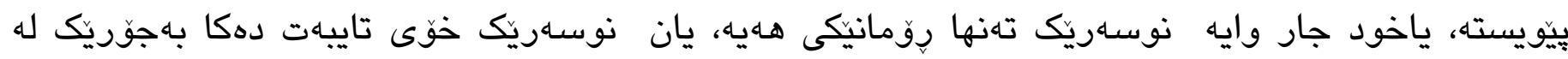

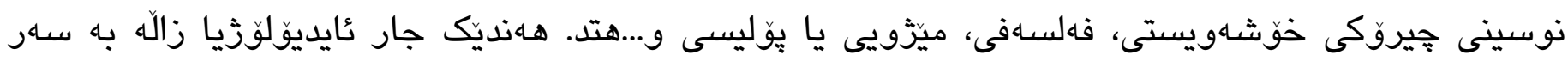

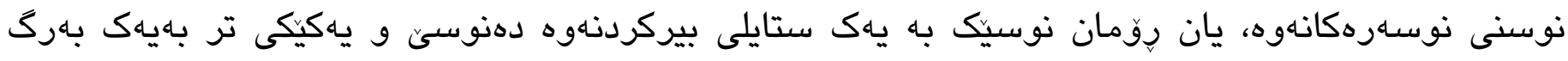

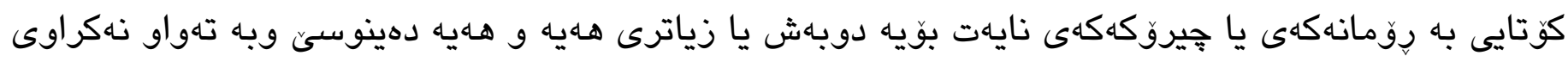

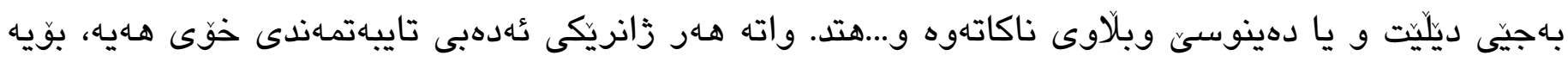

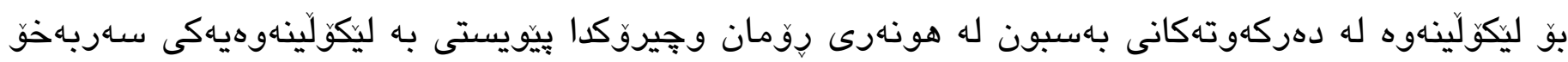

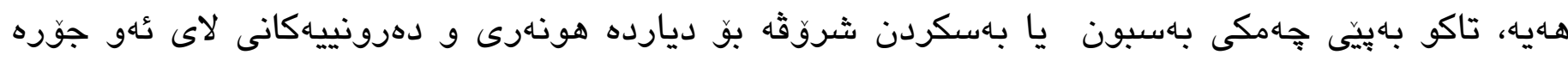
ئهدهبييانه بكهين.

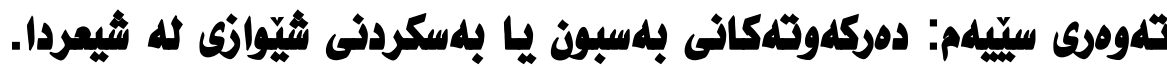

يهكيك له سيما ديارهكانى نوسـار شيّوازى نوسينهكهيهتى، شيّواز يا (ستايلّ يهيوهنديهكى يتهوى سيستيّمى

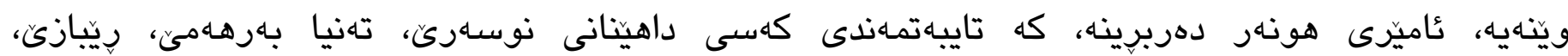

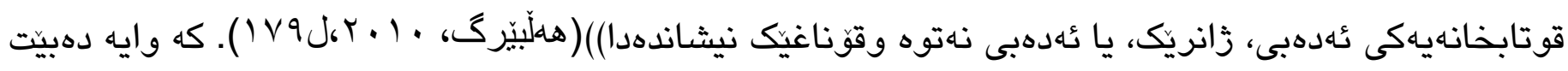

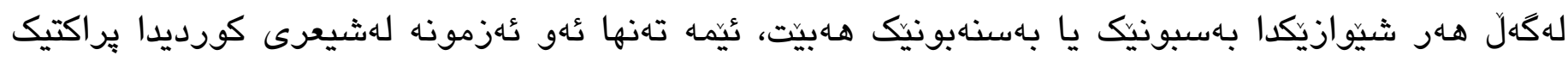

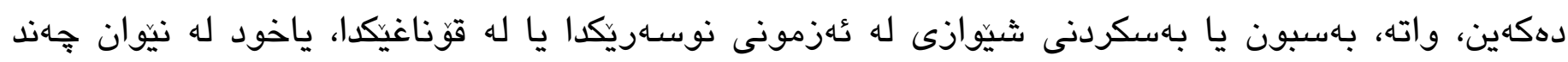
شاعريكدا شروّثه دهكهين. ديارترين دهركهوتهكانى بهسبون يا بهسكردنى شيّوازى له سـه سنورى نيّوان دو قوتابخانه يا دو ريِيازى

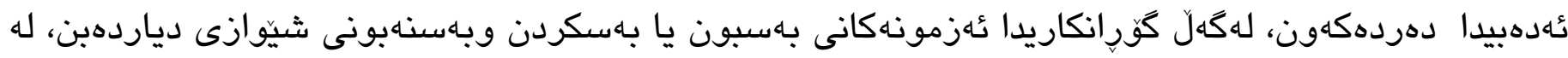
ميزّوى كُهدهبى كورديدا، كاتيك كه قوتابخانهى كلاسيكى له بهرهـههيناندا بهرهو لاوازى دهجيّت ورومانسيزم

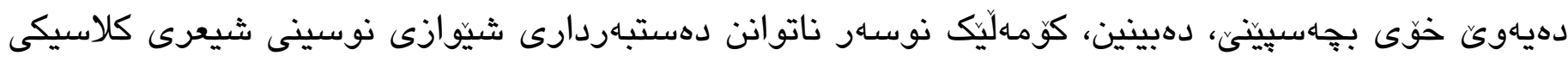

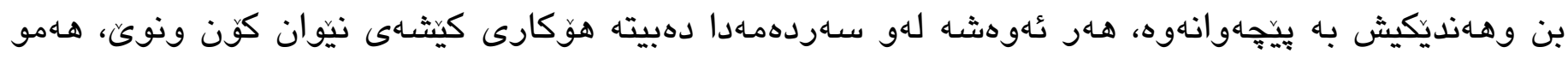

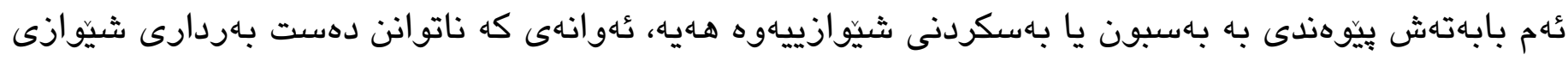
نوسينى كلاسيكى بن هوكارهكهى نهكيشتنيانه به باهبون، تيزر نهبونه له بهكارهينانى ئهو قالَّه شيعرييه، بوّيه

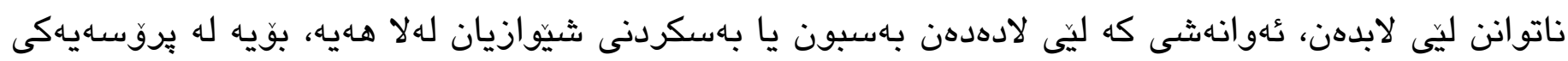
شيّوازى تازهدا خويان تاقى دهكهنهوه. بوّنمونه كه (كَّران) كَهيشته بهسبون يا بهسكردنى شيّوازى له نوسينى

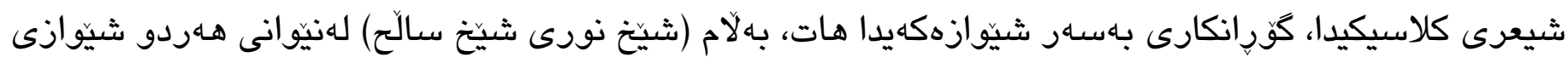

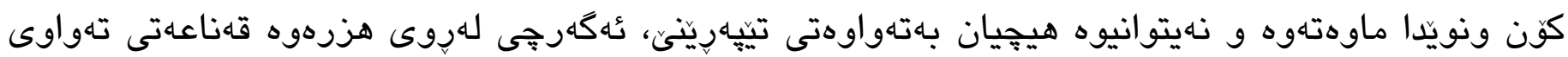




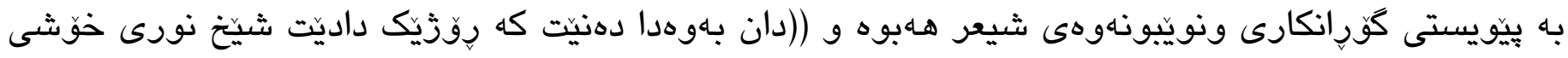

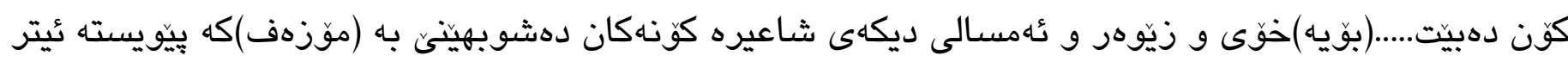
خويان تهقاويت بكهن: (به قانوونيش مووهزهف كُهييه حهددى خُوى، تهقاويته-تهماى جيمان هـيه، تا كهى بزَى

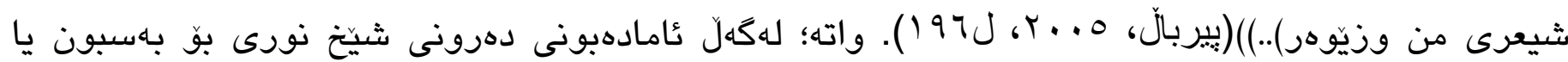

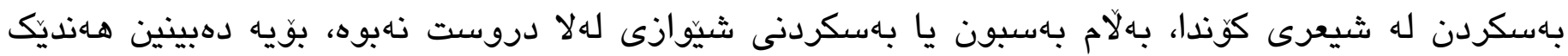

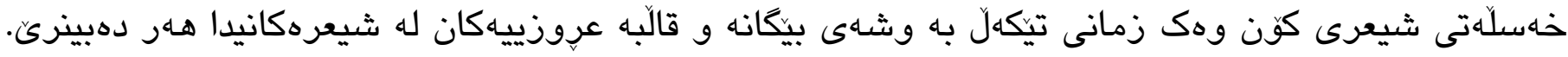

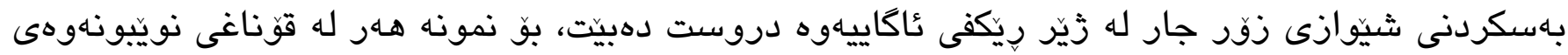
شيعرى كورديدا، لاى شاعيرانى نويخواز بهسبون يا بهسكردنى شيّوازى له بابهتى بهكارهينانى زمانى تيكهلآودا

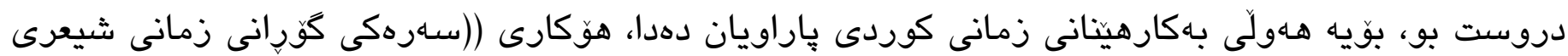
كوردى لله زمانه تيكهلهكهوه بوّكوردييه يهتييهكه له بزوتنهوهانى نويكردنهوهى شيعرى كورديدا بـه

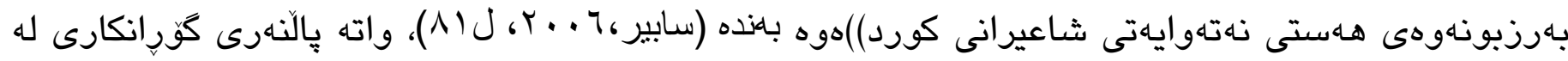
ثيّوازى بهكارهينانى زمانهكه دهرهكييه، بهنده به هـهتى نهتهوهييهوه، ليَرهدا بهسبون يا بهسكردنى شيّوازى

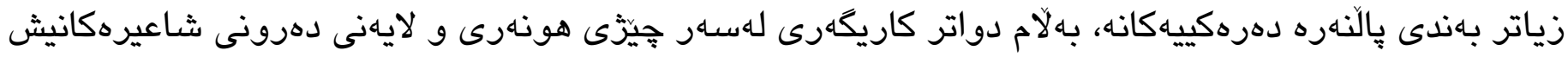

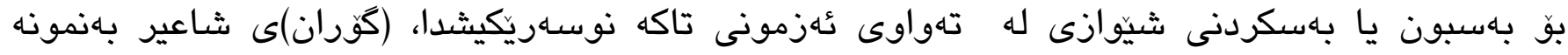

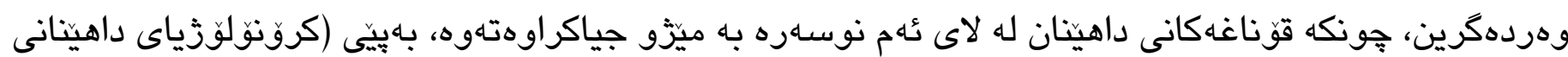

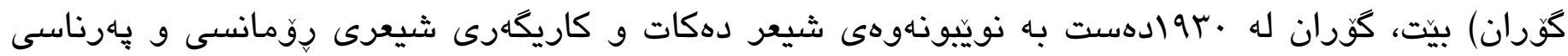

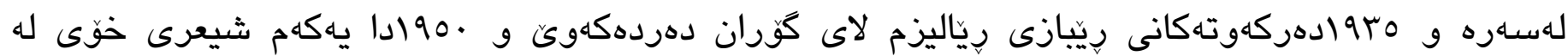

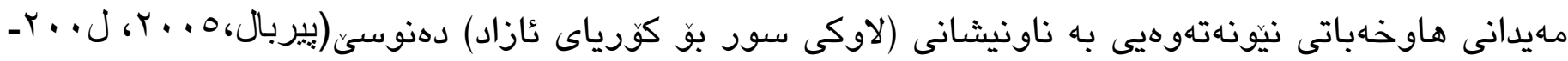

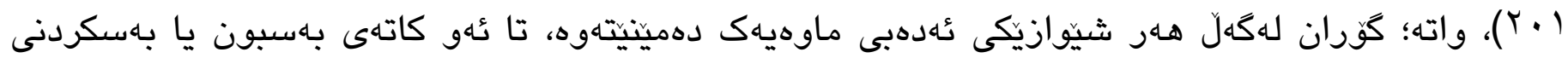

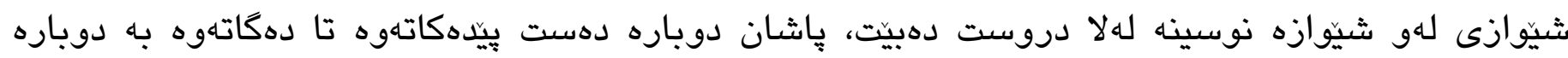

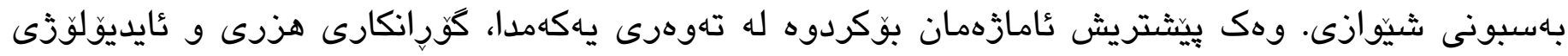

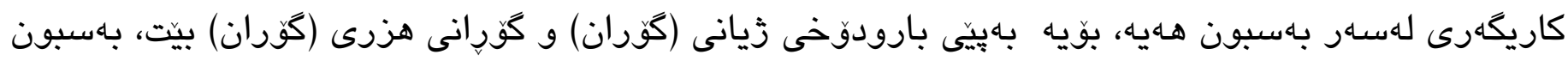
يا بهسكردنى دهرونى لاى كَّران رووى داوه، ئينجا بهسبون يا بهسكردنى شيّوازى دروست بوه، بهسبون لایى

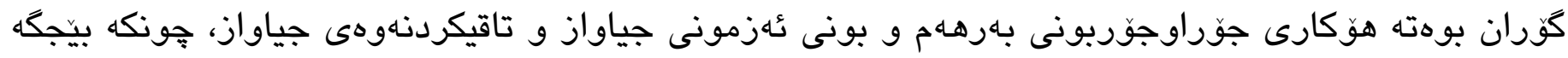
لهوانهى كه باس كرا (كَّران) له بوارى شيعرى مندالَ و كالته كَهٍ و ئوّيهريت و زوّر ستايلى ديكهشدا

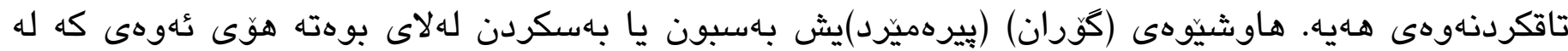

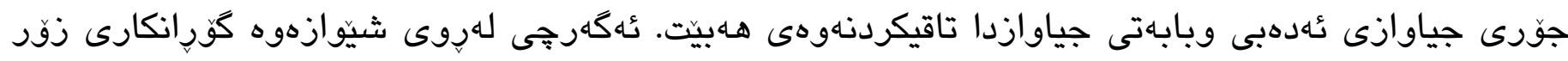
زهق له قوناغه جياجيا كانى نوسينى يِيرهميرد دا نييه و زياتر شيّواز لهلاى بيرهميرد به بـاسوّيى دهروا، بهلاّم

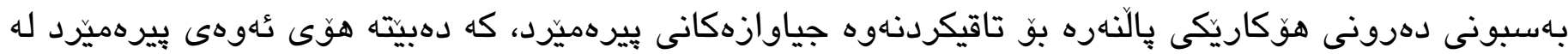




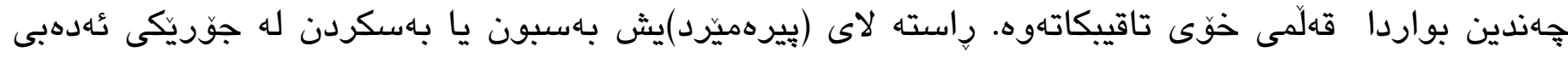

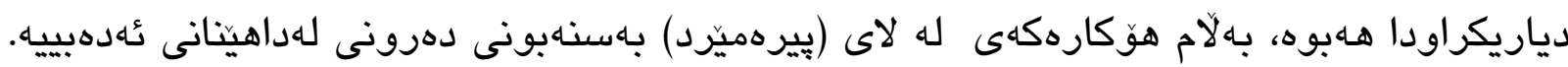

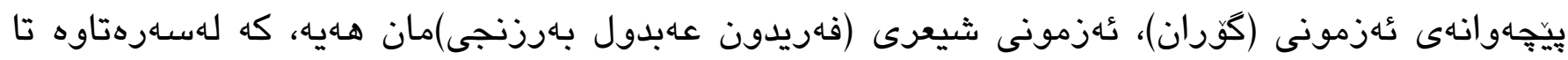
ئيستاش شيوازى نوسينى شيعرى روّمانسى بهسهار تاقيكردنهوه شيعرييهكانيهوه دياره، واته لاى (فهريدون)

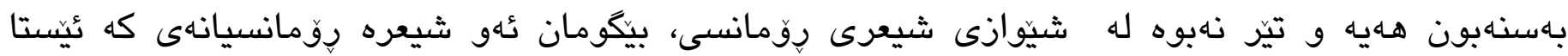

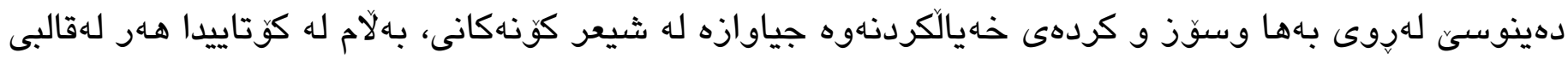
شيعرى رِومانسى ماوهتهوه و بهسبونى شيّوازى بوّ دروست نهبوه. له بابهتى بـسبون يا بهسكردنى شيّوازييدا ئهكهر وردبينهوه بو ناو شيعرهكان هـنديَّ دوخمان بهرجاو دهكهوى، لهوانه بهسبون يا بهسكردنى شيّوازى شاعيران له بهكارهينانى يّاش سـروايهكى ديارى كراودا، كه ياش سـروا ((بريتييه له وشهيهك ياخود رِستهيهك، له دواى هـمو ديّره شيعريّكا وهك خوّى دوباره دهكريتهوه،

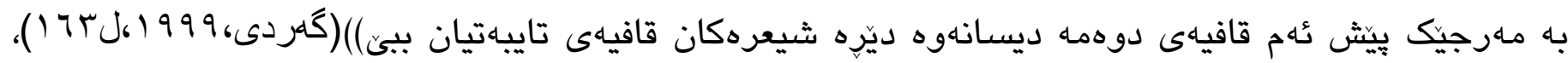

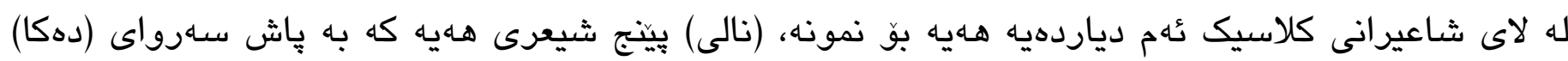

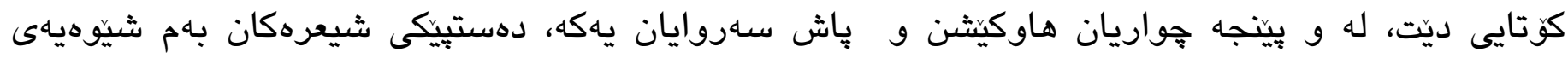
خوارهوهن:

شيعرى يهكهم :-بولبول طهبعم ثئوا ديسا ثهنا خوانى دهكا شيعرى دوهم:-طهبعى شـهكهر بارى من، كوردى ثُكگهر ئينشا دهكا

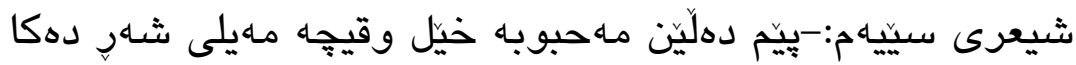

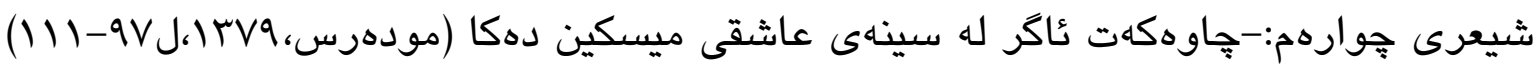

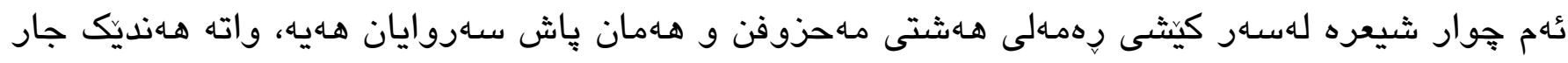

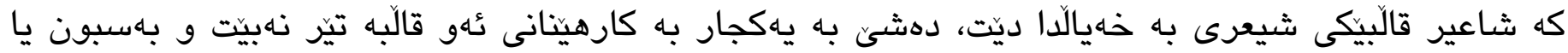

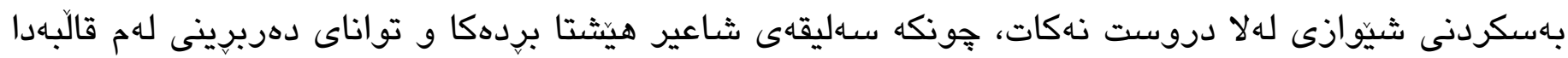
له دهست نهداوه، بوّيه تا ثٔهو كاتهى كه بهسبونى شيّوازى له لاى شاعير دروست دهبيت، ثئوه شاعيرهكه

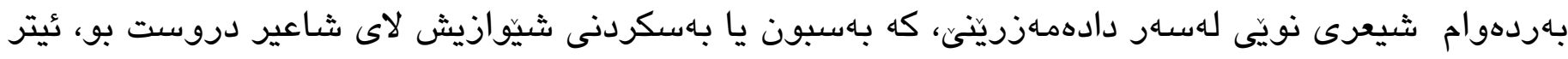

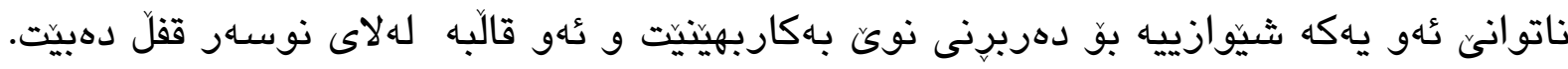

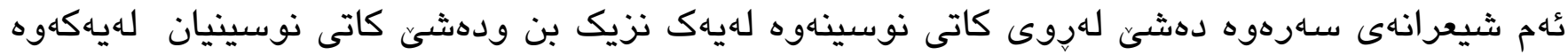

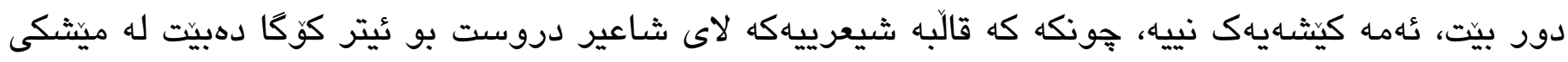

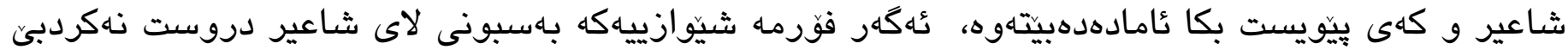

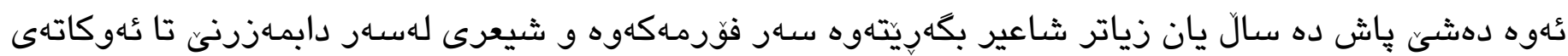
باسبون دروست دهييت. هـروهها درهنگ ياخود زو دهركهوتنى باهبون يا بهاهكردنى شيّوازى له لاى شاعير ئهكار له ئهنجامى لياهاتويى و تواناى ياريكردن بهزمانهوه بيت و زيرهكى شاعير بيّت له قوّستهوهى سروشيكي 


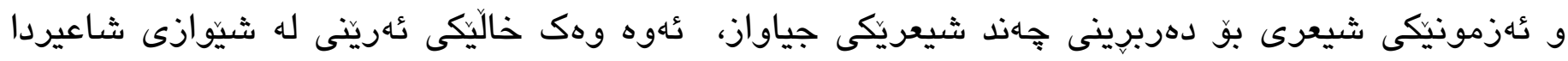

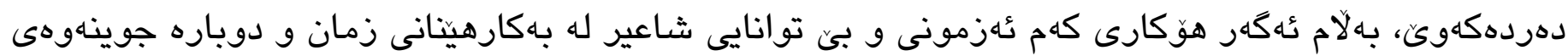

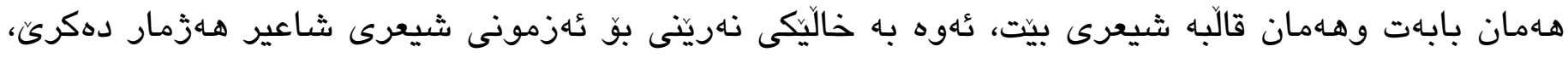

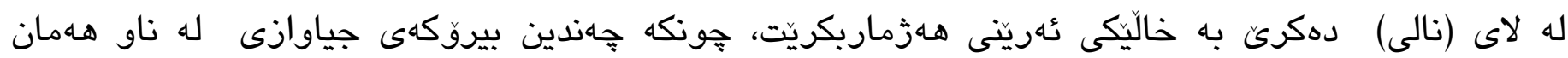
جوارجِيَوهدا له قالبداوه.

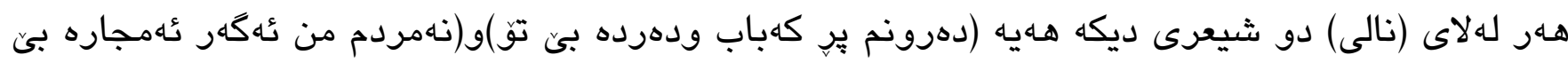

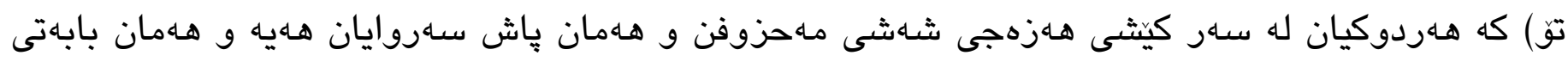
شيعريشيان هـيه، كه ئازارى له دهست دانه و دواندنى كهسى دوههمى تاكه، واته، لهبهرئهوهى بابهت و جوّرى

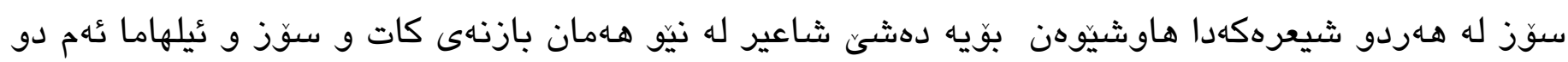

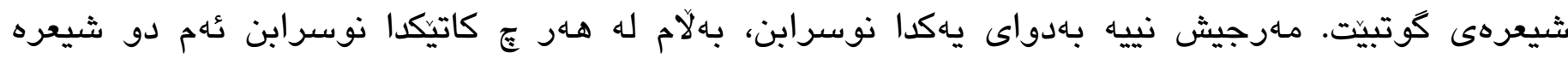

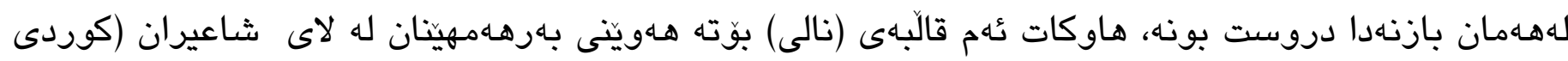
وسـافى)ثدا، قالِّكه لاى (نالى) للهو دو جار بـكارهينان و له دو شيعرهدا دهوهستي، بهلام دهبيته هوَى بـهنهابون

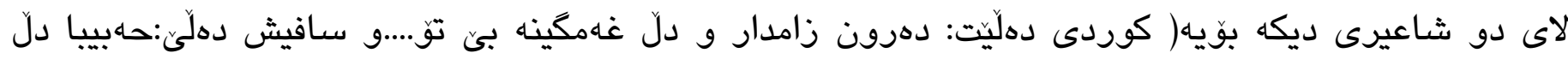

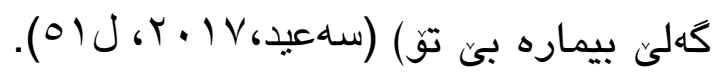
واته لاى ئه دو شاعيره تهنها خوينّنهوهى قالبه شيعرييهكهى (نالى) بهسبونيان للهلا دروست ناكات، تا ئهو كاتهى خوّيان ئزمونى شيّوازهكه دهكهن و كه ئهزمونيان كرد ئينجا بهسبون يا بهسكردنى شيّوازيان لا دروست دهييت. هـهروهها له دو شيعرى ديكهى (نالى)دا كه به دو كيثى جياواز نوسراون، بهلاّم هـهان پياش سـروايان هـايه (كه تق هاتى لهنهوميّىى نهما باس) و(لهكن ئهو جهوهـره فهرده له هيولا نييه باس) لهلاى شاعير له يهك جار بهكارهينانى ياش سـاشرواى (باس) بهسبون يا بهسكردنى شيّوازى دروست نهبوه، بوّيه دوبارهى دهكاتهوه، بهلاّم ئهم جاره له دو قالِّى جياوازدا هـهان يهكهى شيّوازى (باس) دهخاتهوه كار، واته ئهم يهكه شيّوازييه بـه دو دهركهوتن ئينجا بهسبونى لاى شاعير دروستكردوه. واته، هـنديك جار شاعير كه دهربرينيكى بو ديّت ئهوه

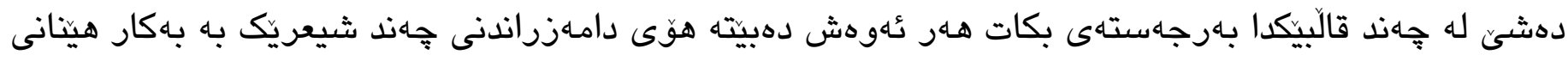

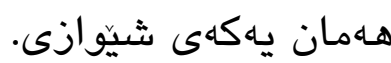
لهديوانى (سالم)يشدا دياردهى دوباره بونهوهى قالِّى ثيعرى و يـكهى شيّوازى دوبارهوه بو زوّره، كه

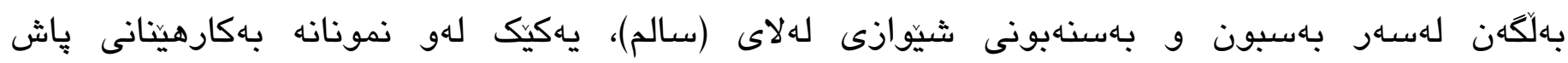

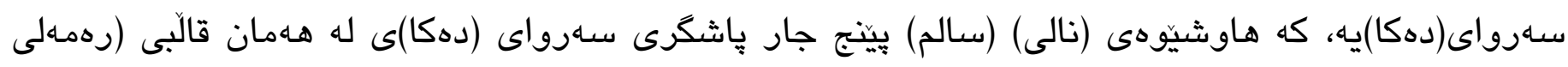
هـشتى مـهزوفدا) بهكارهيناوه، دوان له شيعرهكانى (سالم) نهك تهنها لهكهل شيعرهكانى نالى هاوكيش وهاوسـروان، بـلكو هاوبابهتيشن، (سالم)له شيعرى(كاتيبى فيكرم له دلّا ديققهتئ ئيشـا دهكا) و (توركى يِي

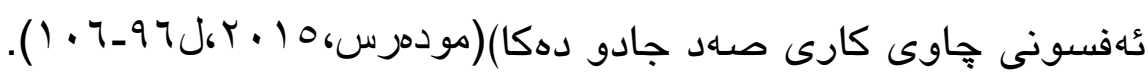




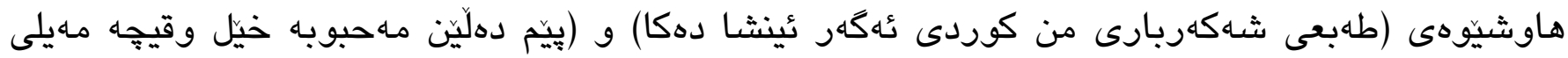

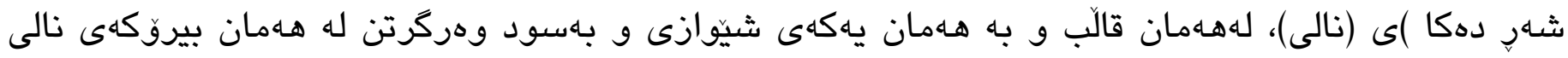

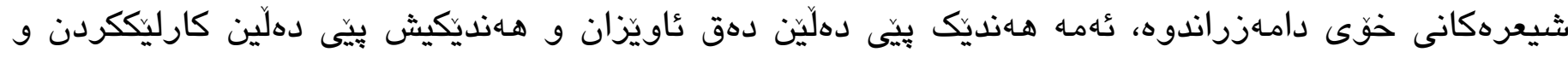

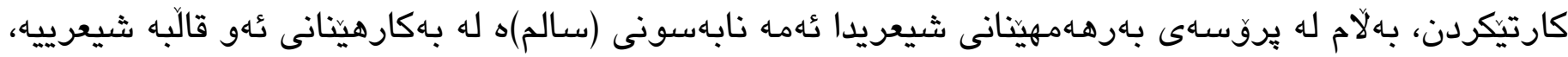

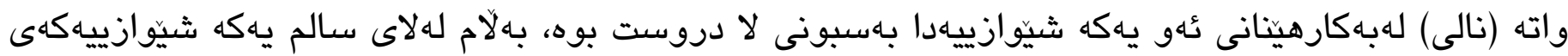

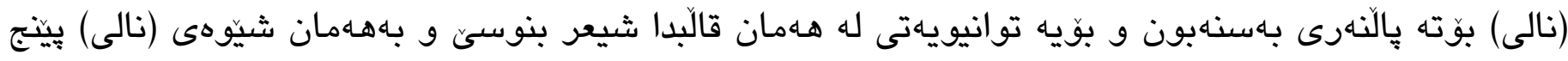

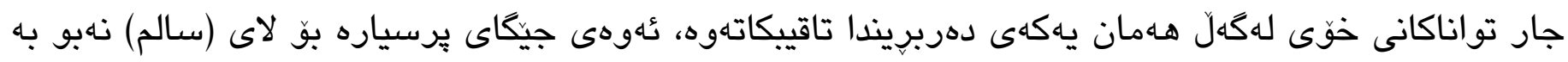

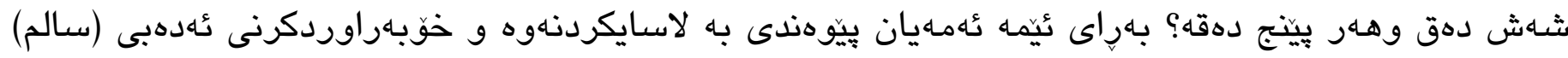

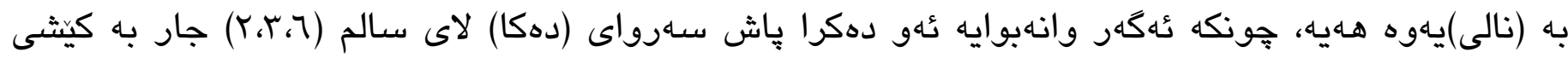
جياوازيش دوباره بييتهوه، واته (سالم) به مـهبهست بهسكردنى شيّوازى له بهكارهينانى ثُهم يهكهى دهربرينهادا

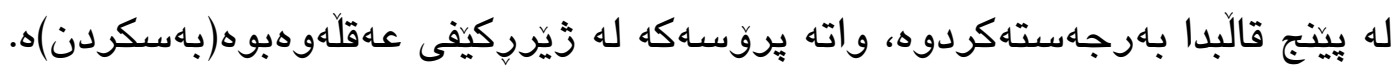
هـار لاى (سالم) شـه جار یاش سـهرواى (نييه) و دوجار (نهبئ) و ده جار (ئهمشهو)و..هتد. بهكارهاتوه، دهركهوتنى يهكهى شيّوازى (ئهمشهو) وهك ياش سـاروا له ده شيعرى جياوازدا نيشانهى بهاهنهبونه له

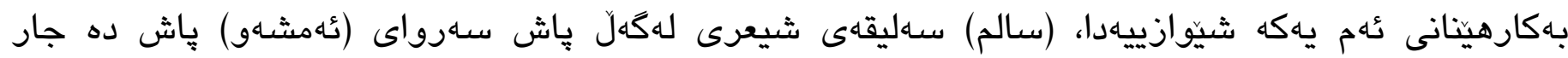

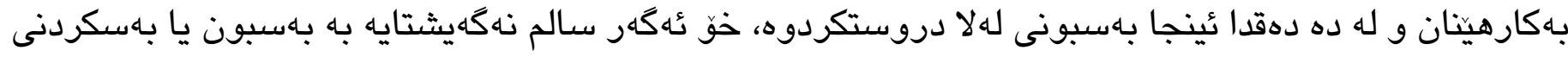

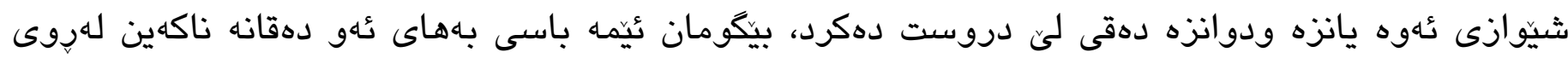
هونهرييهوه تهنها باسى تواناى بـرهـهمينّان و كرده وسهاليقهى شـاعير له بـكارهيناندا دهكهين.

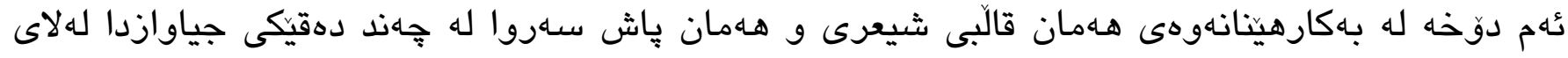
شاعيرانى ديكهش وهكو (كوردى، وهفايى، مهحوى...هتد) بـرجاودهكوىی، واته كهيشتن به بهسبون يا بهسكردنى شيّوازى له لاى شاعيرانيش وهكو ديارده بونى هـيه، ئيمها تهنها لهلاى مـهلاى (جزيرى) ئهم دوخهمان بهرجاو

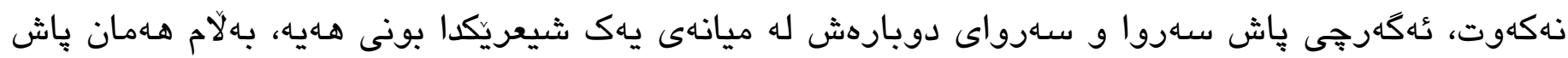
سـروا له جههند دهقيكدا دهرناكهويت.

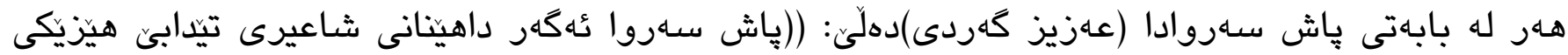

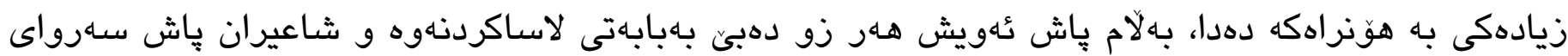

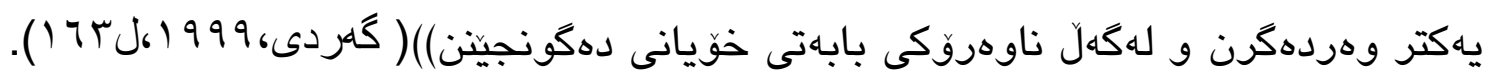

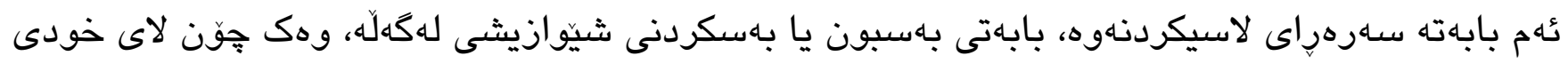
شـاعيرهكه، كه بهسبون يا بهاهكردنى شيّوازى رِونادا، دهبينين جههندين جار هـامان پِاش سهـروا بّ دهقهكان باهكاردينيتي، به هـمان شيّوه لاى شاعيرانى ديكه ش وايه، بهلام جياوازييهكهى لهوهيه كه خاوهنى بيروكهكه نين

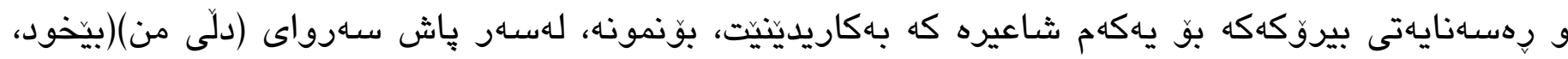

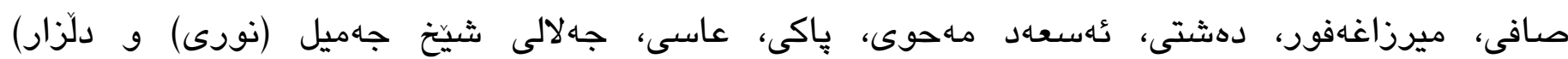




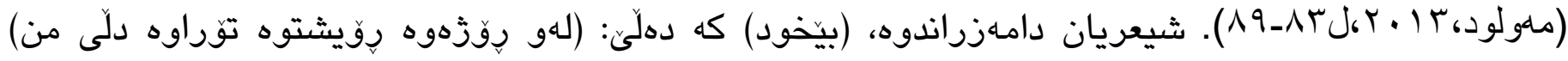

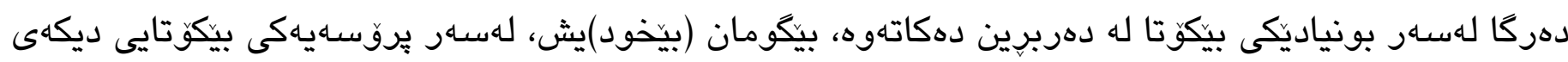

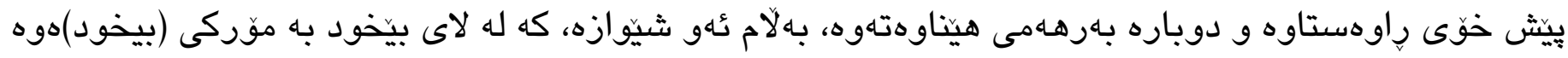

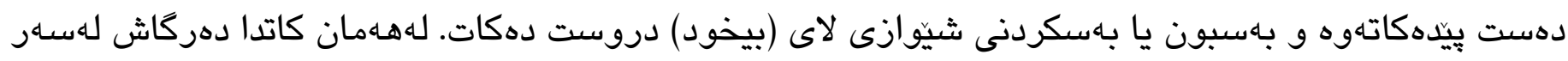
باهنهبونى شيّوازى لاى شاعيرانى ديكه والآ دهكات، بوّيه دهبينين لاى شاعيرانى ديكه ثئه شيّوازه دوباره

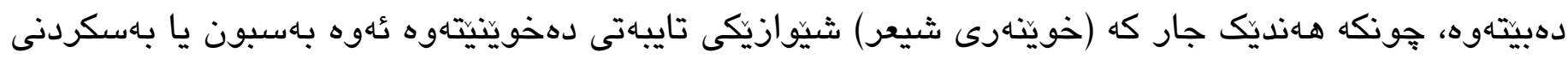

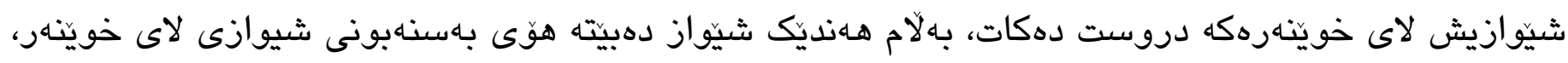

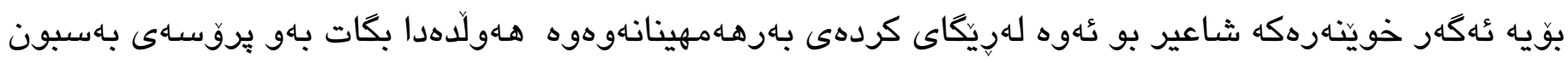

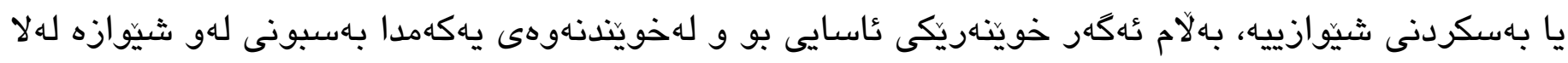

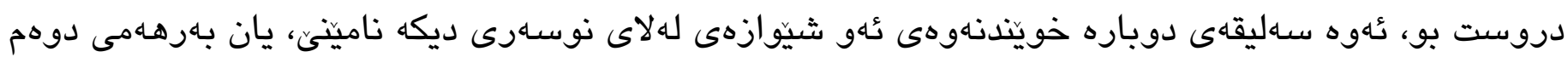

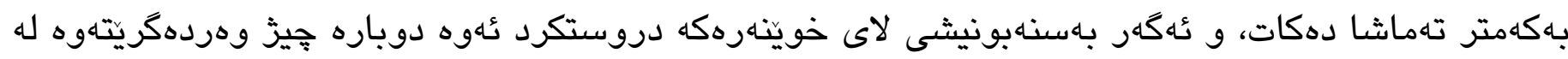
خويندنهوهى هـهان شيّواز و له شوينتى جياوازدا. هـانديكّ جار بهسنهبون لاى شاعيرهكه تهنها له بهكارهينانى پِاش سـرواكهدا نييه، بهلكو له بهكارهينانى

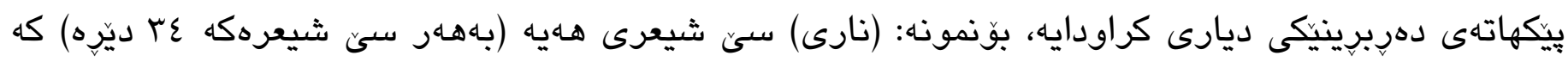

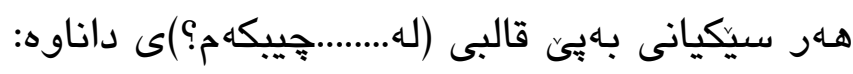

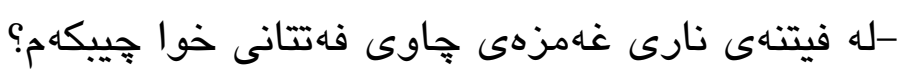

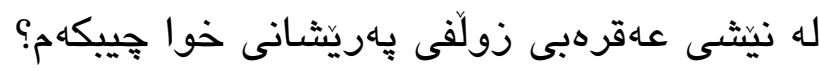

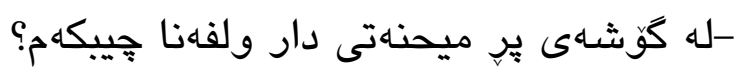

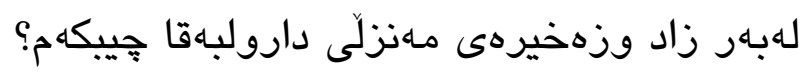

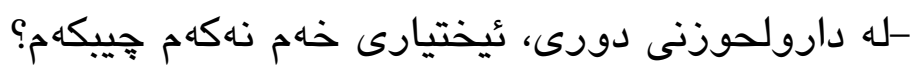

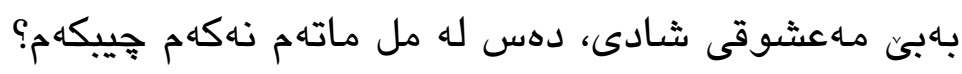

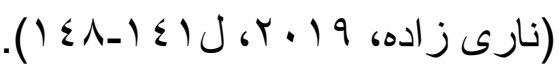

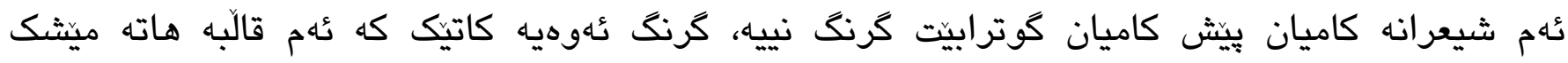
شـاعيرهكهوه تا بهسبونى لا دروست نهبو هـهر بهكاريهينّا، دهثيّ كه شيعرى يهكهمى نوسيبيت ديّريّكى لادروست

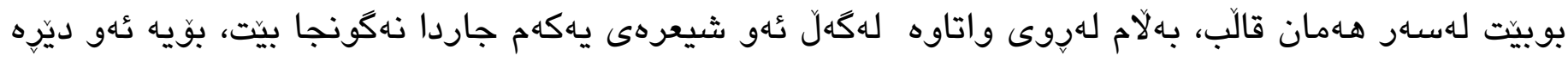

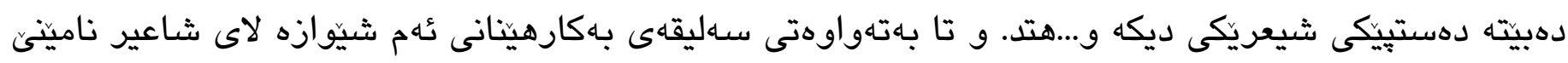
يروّسـكه بهردهوام دهبيت و كه بهسبون يا بهسكردن رودهدات كردهوهى بهرهـههينانهكهش له بهكارهينانى ئهو قالبهـدا دهوستينت.

بابهتيكى ديكه لهبابهتهكهنى بهسبون يا بهسكردنى شيّوازى شيعريدا بابهتى دوباره بونهوهيه، بوّنمونه لهتيف

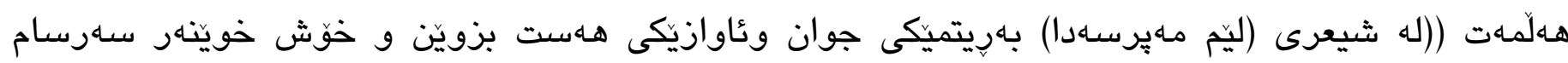




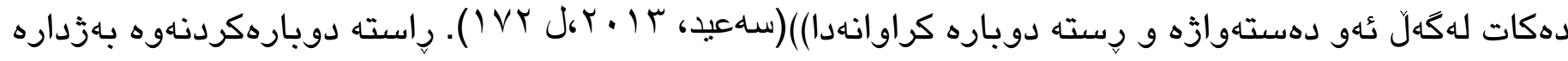

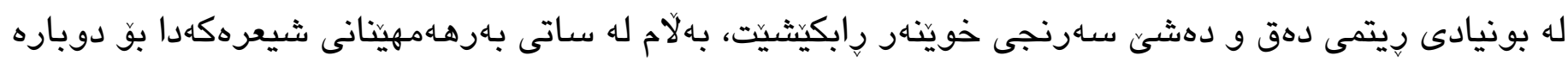
دهبيتّاهوه؟ لهتيف هـالمّهات دهلّي: - جوّن هـاست بـ برسينتى دهكهم جُون هـاهت به تينويهتى دهكهم

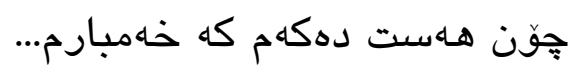

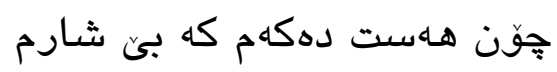

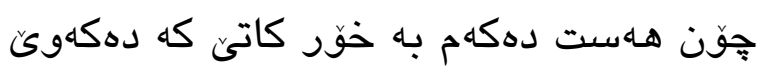

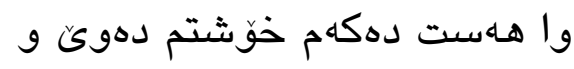

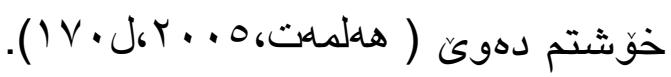

لهم شيعرهدا شـاعير له زيّر رِيَفى واتاوه، شيّواز دوباره دهكاتهوه، واته تا شـاعير لهروى ماناوه تيّر دهبيت

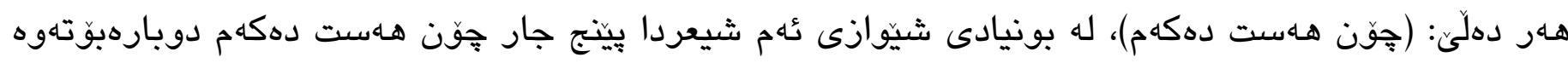
و به يّينج جاربهكارهينان، ئينجا لاى شاعير بهسبون يا بهسكردن دروست بوه و كه بهسبون دروست بوه ئيتر

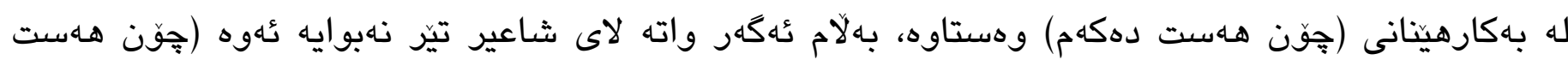

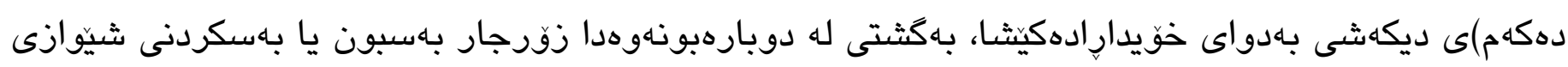

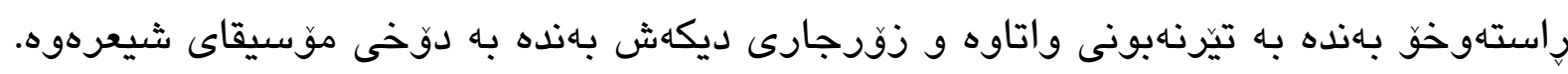

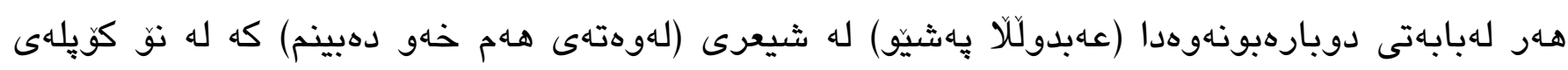
ثيعر يّيك هاتوه، له دهستينيكى شيعرهكه وله كوتاييهكهى هـهان كويله دوباره دهكاتهوه، دهلّي:

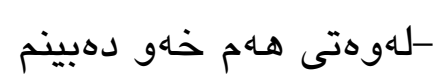
خهونى مـهمـاريى و خاسرهن خهونى بلْند وهك ئهستيره

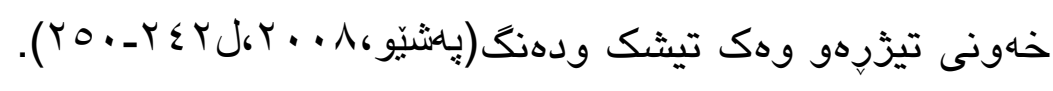

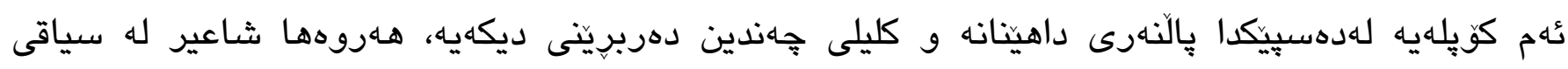

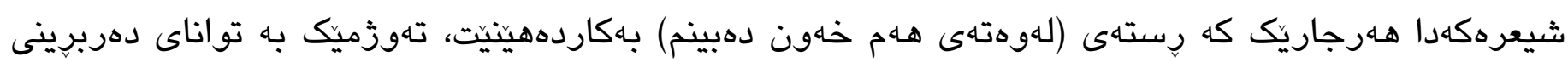

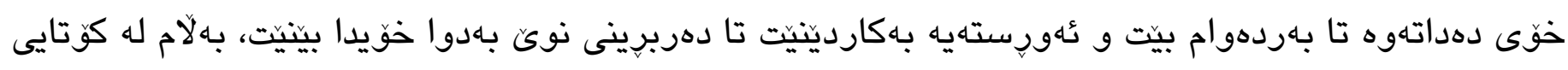

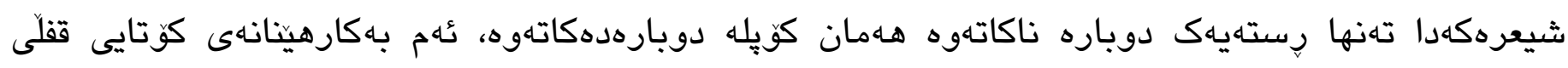
بابهتهكهيه و نيشانهى بهسبون يا بهسكردنى شيّوازى ودهرونى شاعيره له بهكارهينانى ئهم شيوازه و و ئهم بابهـهدا.

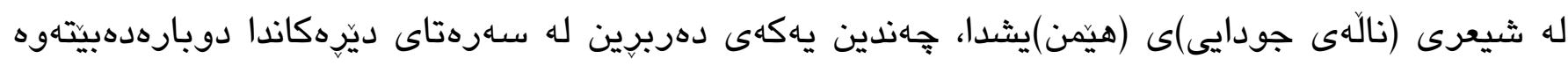

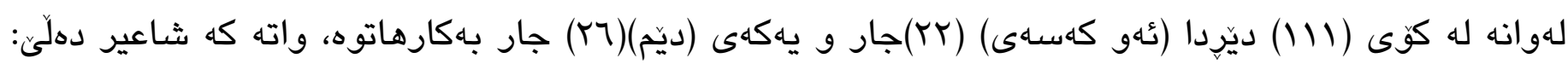




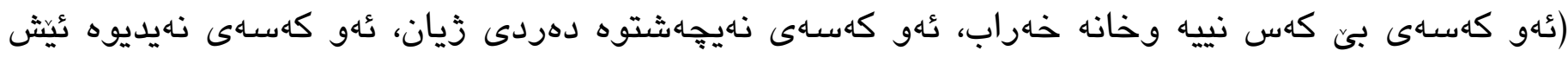
وبرك وزان....هتد) و (ديّم بهرهو كويّتان بهرهو باخى بهاهـشت، ديّم بهرو زيخ وجهاهو وكانياوى خوّم، ديّم

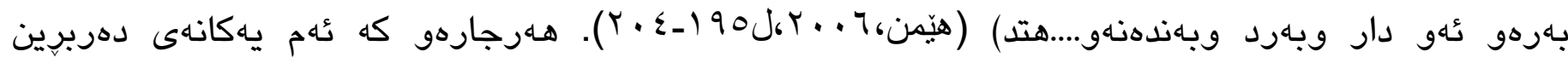

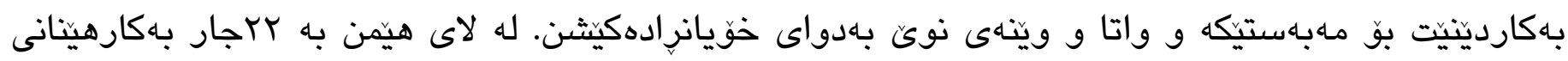

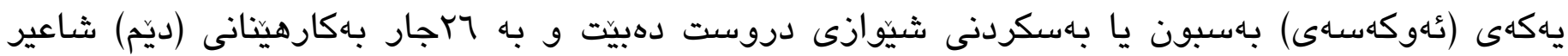
دهكاته بهسبون يا بهسكردنى شيّوازى له بهكارهينانى عاهم يهكهى دهربرينهدا. هـار له بابهتى بهسبون يا بهسكردنى شيّوازى له بهكارهينانى يهك يهكهى زمانى، كه شاعير له جههند دهربرينيكدا دوباره بهكاريدهينيتهوه، نمونهى وهفايى دينينهوه، (وهفايى) له تهواوى شيعره كورديهكانيدا سنى

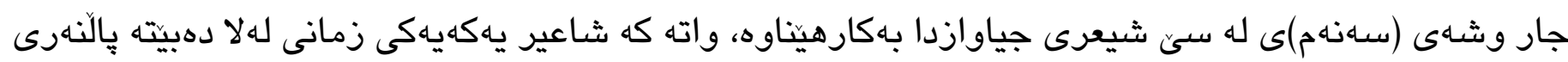

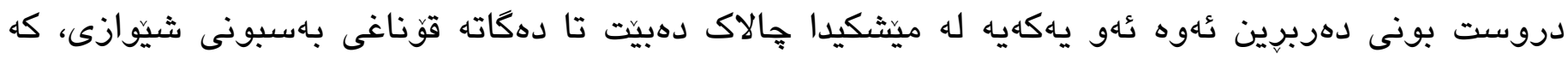

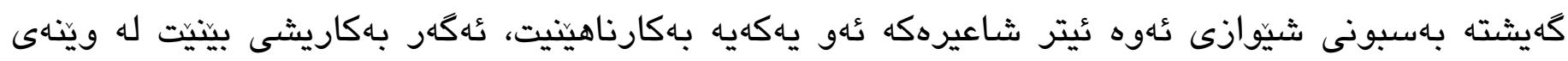

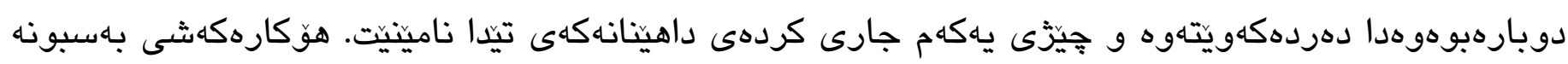
شيّيوازييهكهيه، لهم نمونانهى وهفاييدا وهفاى له سيّ دهركهوتهدا سهنهم بهكاردينتيت، كه بريتين له: -لهو شاره خهدهنكى سهنهميكم له جگهردا

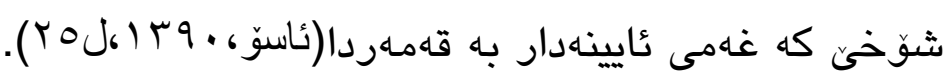

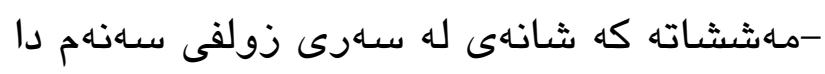

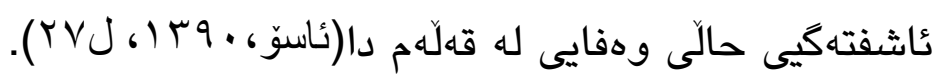

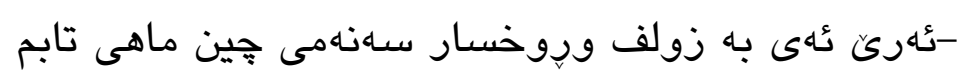

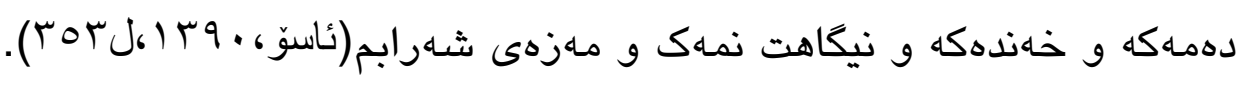

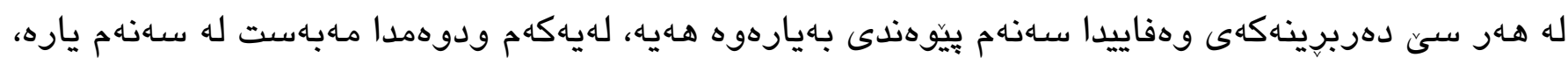

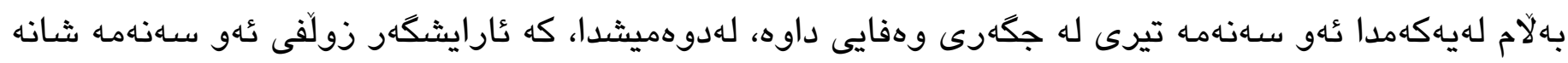

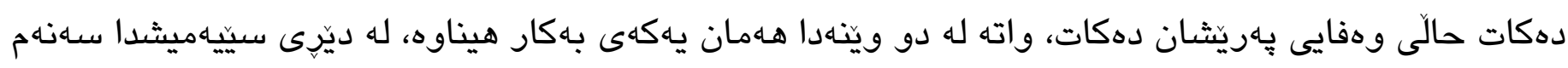

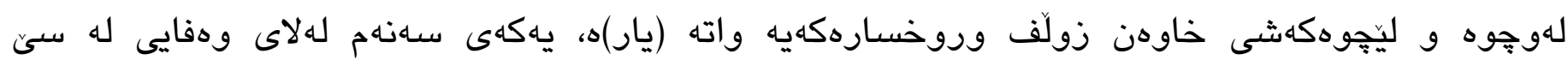

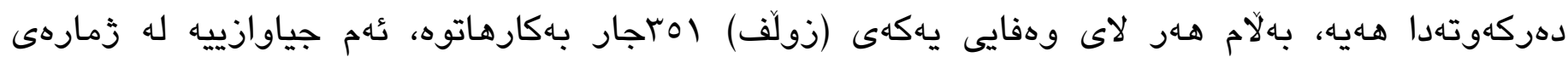

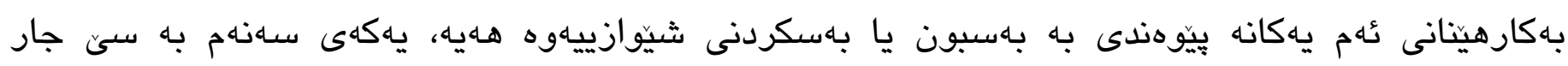

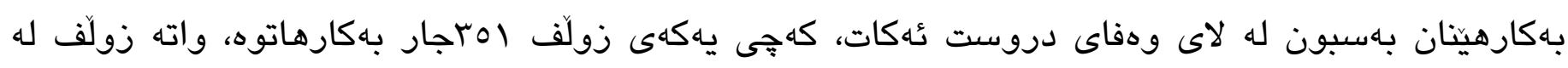

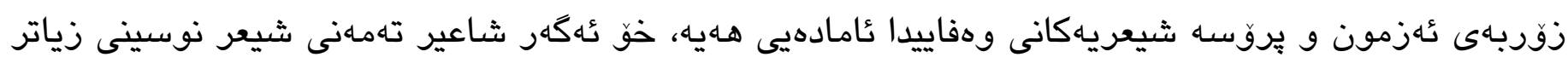

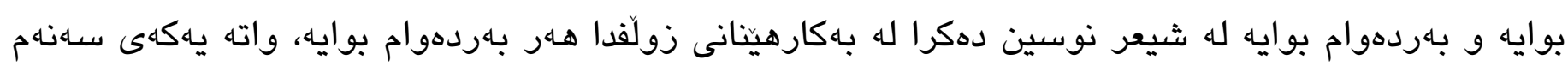
لهو يهكانهى دهربِينه كه زو شـاعير كهيشتوته بهسبون يا بهسكردنى شيّوازى له بهكارهينانيدا، بهلاّم زولّف سروشتيكى لاستيكى هـيه بوّيه له ثئزمونهكاندا دوبار بهكارديتهوه و شـاعير زو ناكاته بهسبيونى شيّوازى له 


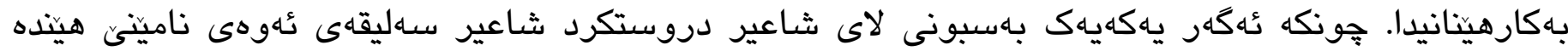
دوبارهى بكاتهوه.

دوخهكانى بـسبون يا بـاهكردنى شيّوازى و دهركهوتهكانى زوّره و دهكريّت له ئهزمونى تاكه شاعيرينك

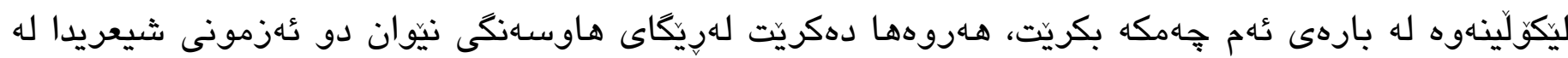

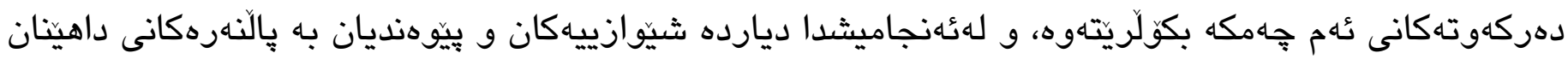

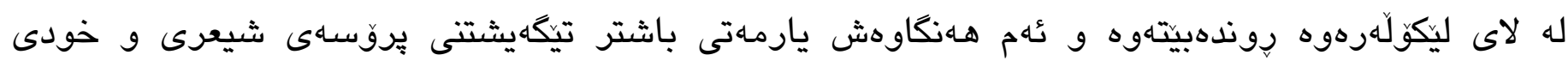
شيعريش دهدات.

\section{كُنجمام}

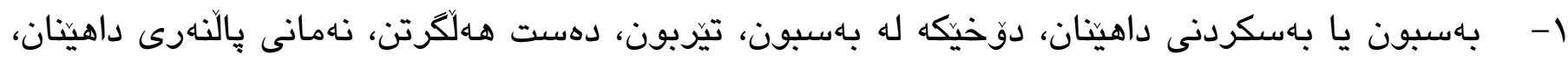

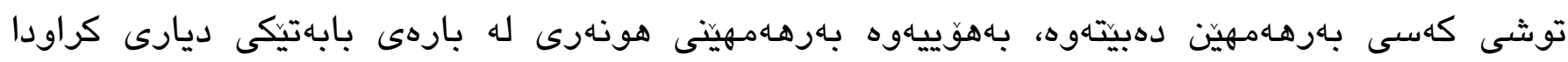
سـاليقهى دروستكردنى باهرهـاميكى نوينى نابيت.

ץ- دو جورى بهسبون يا بهسكردن هـهيه لاى داهينّهر بهسبون يا بهسكردنى دهرونى و بهسبون يا

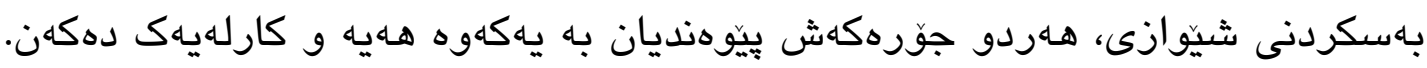

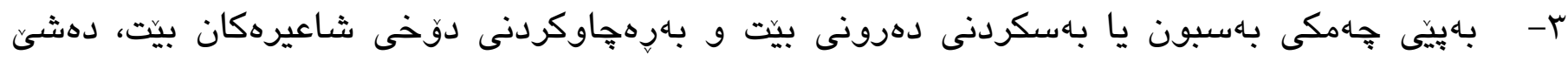
بلّينين: كهسانيكى وهك (وهلى ديوانه، محمد عومهار عوسمان، ئهمهاد هـردى وجهاندانى تر) شيعر له لايان

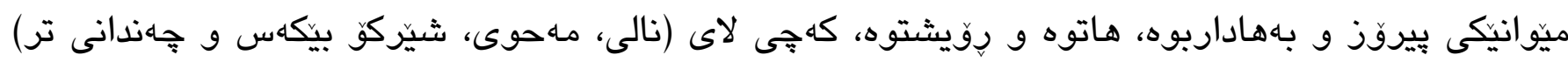

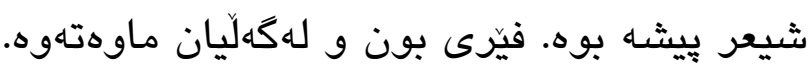

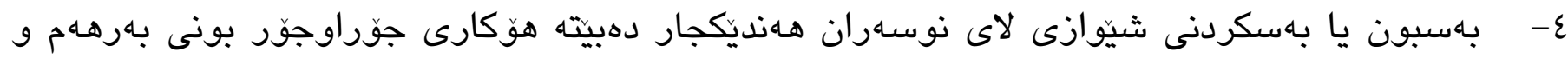
بونى ثٔزمونى جياواز و تاقيكردنهوهى جياواز. هـنديكجارى ديكه ش دهبيته هوَى كهمى بهرهـهى ثـاعيرهكان.

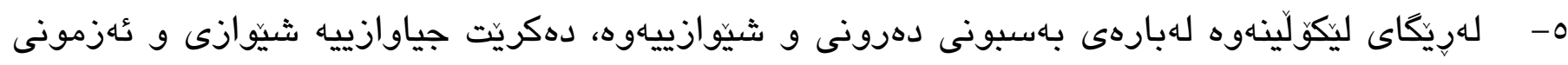

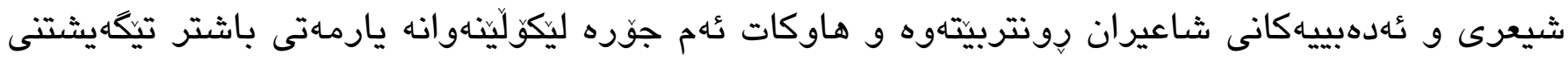
كردهى شيعر نوسين و بابهتى ئيلهام و فيزربونى شيعر دهدات. 


\title{
The Art and Literature Areativity, Kurdish Poets and Poems As An Example
}

\author{
Arkhawan Mohammed Obaid \\ Kurdish Language Department, College of Education for Human Sciences, University of \\ Kirkuk, Kirkuk, Iraq. \\ E-mail: Arkhawanmohammed83@gmail.com
}

\begin{abstract}
:
Abstract The art and literature creativity, Kurdish poets and poems as an example is the name of a theoretical and practical research. It is theoretical because in the first part it presents the principles and the regulations of the research for the first time. And it is practical because in the second and third parts of the the research is : Supported in a way of practicing the ideas in Kurdish pomes and the experiences of Kurdish poets, the situation of stopping creativity is a situation of repletion, fullness, giving up, satisfaction,missing creativity and initiative for creativity that happens to the producers person in which the producer is not able to produce new products or things. This repletion could be temporary or permanent. It has two types ( psychological and formational repletion) This research can be applied to all types of practical arts but in this research it is just practiced on Kurdish pomes only. This research is based on both the psychological and the formational terms. The research presents the important aims of the research, defining the terms, classifying the motivators of creativity and it is effects on the poets products.
\end{abstract}

Keywords: Repletion, Fullness, Non Fullness, Producer, Creativity, Motivation and Stopping. 


$$
\text { ئاسوّ،موحهمهد( •وبr().ودفايى(ديوان)، سنه: انتشارات كوردستان }
$$

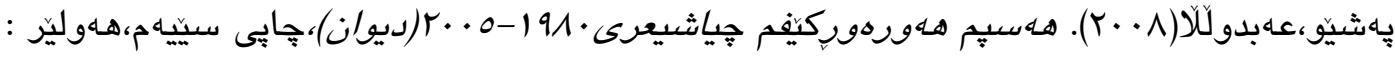

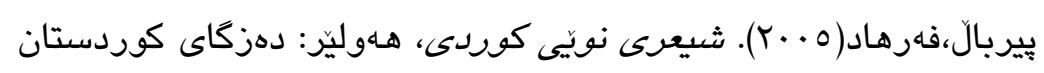

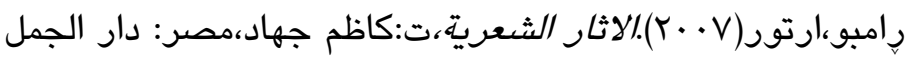

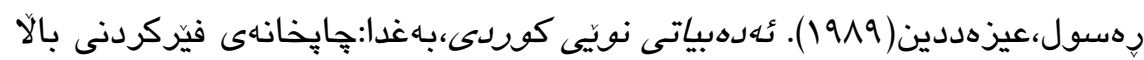

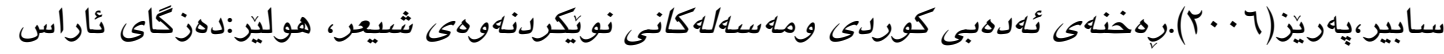

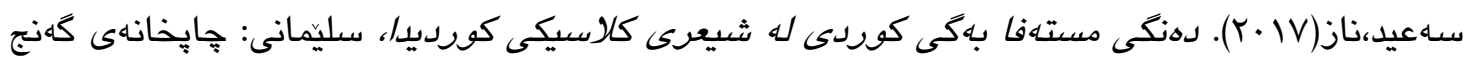

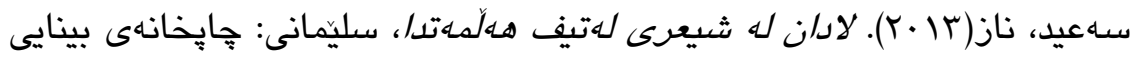
سيوهيلى،ريّيوار(7 (1). كتيبى حاجى قادرى كوقيى، هـهوليّز:بلاوكراوهى ئهكاديمياى كورد.

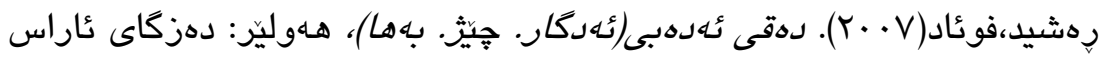

عهبولكهريم،محمدى مـلا ( •191)...كوران(ديوان)، جايیى يهكهم، بغداد: مطبعه المجمع العلمى العراقى

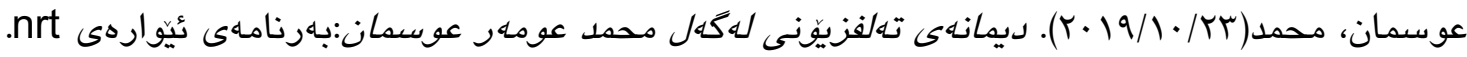

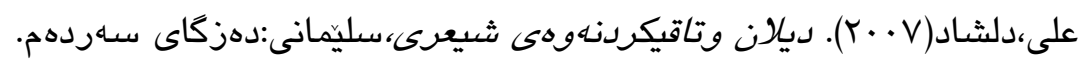

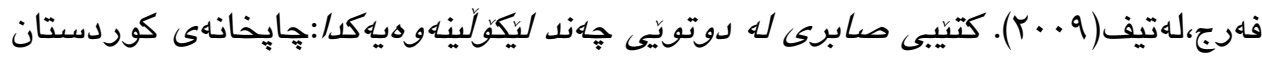

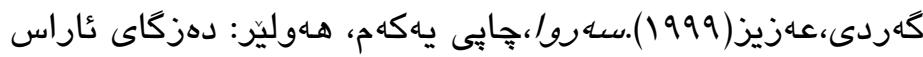

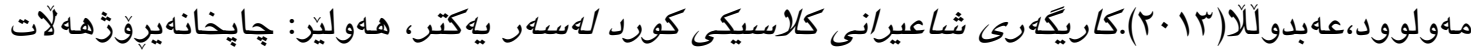

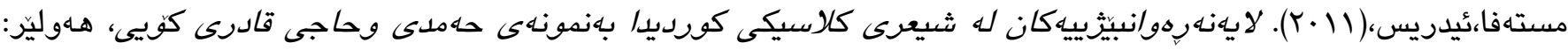
كهكاديمياى كورد. مودهرس، مهلا عهبدولكهريم (10 (Y). سالم(ديوان)، بهركى يهكهم سليمانى: بنكهى زين مودهرس،عهبدولكهريم (rV9 (). نالى(ديوان)، جايبى دوهم، سنه : انتشاراتى كوردستان

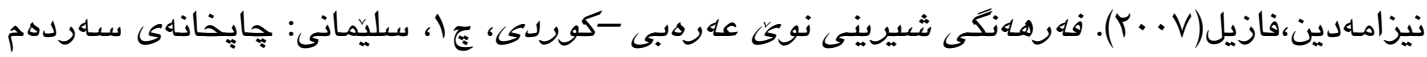

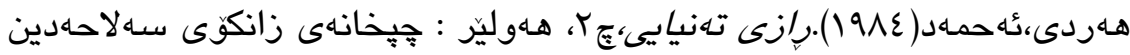

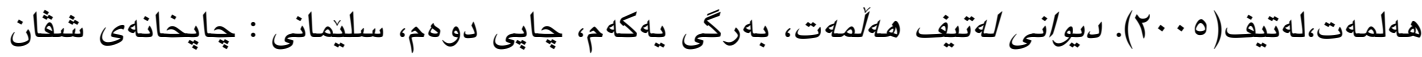

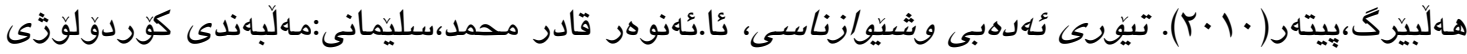

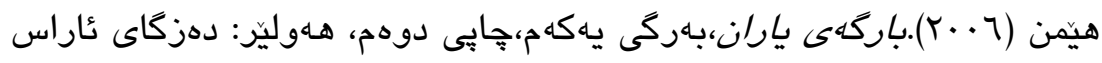




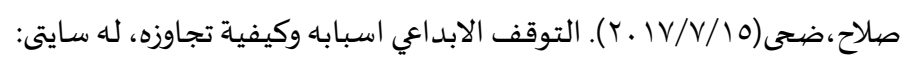

https://www.noonpost.com/content/18875.

$$
\text { الرحبي، احمد()،سيرجي يسينين لذة الحياة والشعر، جهة الشعر، لة سايتي: }
$$

http://www.jehat.com

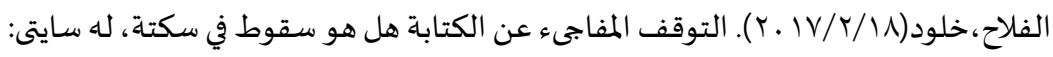

$$
\begin{aligned}
& \text { https://alarab. co.uk }
\end{aligned}
$$

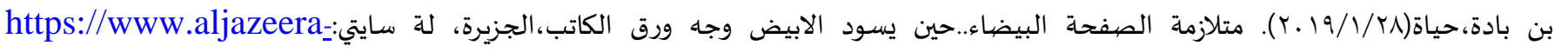
net.cdn>ampproject.org

مريم،غضبان (0 . ب-7 . . . .مساهمة الاسرة في ضهور السمات الابداعية لدى الطفل،رسالة ماجستير،كلية العلوم الانسانية والاجتماعية، الجزائر :جامعة منتوري-قسنطينية مطلوب، احمد( ( . (Y). معجم المصطلحات البلاغية و تطورها، لبنان: مكتبه لبنان ناشرون 